\title{
PUTUSAN HAKIM YANG BERKAITAN DENGAN KASUS PERTANAHAN
}

\author{
Trie Sakti, SH CN
}

\author{
BAB I \\ PENDAHULUAN
}

\section{A. Latar Belakang}

Meningkatnya masalah pertanahan akhir-akhir ini sangat mempengaruhi kinerja BPN. Produk yang dihasilkannya yaitu sertipikat yang seharusnya memberikan perlindungan hukum dan menumbuhkan rasa aman kepada masyarakat karena memberikan kepastian hukum sebagaimana yang dijanjikan kepada masyarakat dalam UUPA telah menjadi sengketa yang digugat melalui jalur pengadilan.

Dari laporan perkara yang ditangani oleh Subdit Penyelesaian Sengketa Hukum, Direktorat Pengurusan Hak-Hak Atas Tanah, Deputi Bidang Pengkajian dan Hukum Pertanahan, BPN pada bulan Pebruari 2002 diperoleh informasi tentang proses sengketa tanah di peradilan Tata Usaha Negara (TUN) maupun jalur peradilan umum. Dari 157 perkara yang diajukan melalui Peradilan Umum, terdapat 39 perkara yang diteruskan ke Mahkamah Agung, sebanyak 13 perkara telah diputuskan, dua di antaranya BPN di pihak yang kalah. Sedangkan dari 197 perkara yang diajukan melalui peradilan TUN, terdapat 37 perkara yang telah diputuskan, delapan perkara di antaranya BPN dinyatakan kalah.

Hasil penelitian Puslitbang di 10 Kabupaten/Kota pada tahun 2002 juga menunjukkan bahwa masalah pertanahan yang berkaitan dengan pelaksanaan putusan pengadilan telah menempati urutan ketiga dari delapan kelompok masalah, dengan bobot sekitar $21,6 \%$ dari jumlah yang terjadi.

Kasus-kasus pertanahan yang timbul tersebut banyak terjadi karena kurangnya alat bukti kepemilikan atau jika terjadi perubahan pemilikan baik karena pemindahan hak atau peralihan hak tidak segera didaftarkan. Masalah pertanahan yang timbul tersebut, dapat terjadi karena lemahnya administrasi pertanahan, serta faktor lain seperti pemalsuan alat bukti baik akta waris, girik, akta PPAT termasuk juga perbedaan penafsiran para hakim terhadap peraturan pertanahan yang dikaitkan dengan peraturan dalam hukum perdata dan hukum pidana. Berbagai gugatan dari masyarakat terhadap produk BPN juga telah mengakibatkan penangkapan beberapa pejabat Kantor Wilayah BPN dan Kantor Pertanahan sebagai konsekuensi kebijakan yang diterapkannya.

Dalam konteks tersebut keputusan hakim sering tidak merujuk kepada peraturan yang melandasai kinerja BPN. Sebagai contoh Keputusan Mahkamah Agung Republik Indonesia No. 393 K/Sip/ 1973, tanggal 11 Juli 1973, intisari dari putusan itu adalah surat-surat ketitir tidak merupakan bukti yang menguatkan adanya hak milik, tetapi hanya dinilai sebagai tanda pembayaran pajak saja. 
Kasus-kasus yang sudah diputuskan hakim dalam Pengadilan TUN dapat kembali digugat di peradilan umum. Hal ini dapat mengganggu kelancaran pelayanan pertanahan kepada masyarakat dan menimbulkan rasa was-was atau khawatir adanya kemungkinan gugatan terhadap produk yang dihasilkan.

TAP MPR No. IX/MPR/2001 telah memberi arahan perlunya pananganan masalah pertanahan dengan menyelesaikan konflik-konflik pertanahan yang berkenaan dengan sumber daya agraria yang timbul selama ini sekaligus dapat mengantisipasi konflik di masa mendatang guna menjamin terlaksananya penegakan hukum dengan didasarkan atas prinsip-prinsip sebagaimana dimaksud dalam pasal 4 ketetapan ini.

Melihat jumlah perkara yang ditangani peradilan di atas, maka untuk mengurangi volume permasalahan dan dampaknya terhadap kinerja BPN diperlukan adanya informasi mengenai (1) jenis-jenis pelayanan pertanahan apa saja yang potensial menjadi sengketa dan faktor-faktor yang mempengaruhinya, (2) bentuk putusan pengadilan terkait dengan produk pelayanan pertanahan yang bermasalah dan (3) kebijakan pertanahan yang berpotensi menimbulkan masalah.

Sehubungan dengan hal itu pada tahun 2004 penulis melakukan penelitian tentang "Putusan Hakim Yang Berkaitan Dengan Produk Pelayanan Pertanahan".

\section{B. Perumusan Permasalahan}

Berdasarkan latar belakang tersebut di atas diperoleh suatu hubungan sebab akibat antara permasalahan produk pelayanan pertanahan dengan putusan pengadilan. Maka masalah yang diteliti dirumuskan sebagai berikut :

a. Jenis sengketa apa saja yang sering diajukan ke Pengadilan dan faktor-faktor yang mempengaruhinya ?;

b. Bagaimana bentuk putusan peradilan terkait dengan produk pelayanan pertanahan yang saling bertentangan?;

c. Apakah solusi untuk mengurangi/menghindari gugatan terhadap produk pelayanan pertanahan.

\section{Tujuan Penelitian.}

a. Mengetahui jenis sengketa apa saja yang sering diajukan ke Pengadilan dan faktor-faktor yang mempengaruhi:

b. Mengetahui bentuk putusan peradilan terkait dengan produk pelayanan yang saling bertentangan;

c. Gambaran solusi untuk mengurangi/menghindari gugatan terhadap produk pelayanan pertanahan.

\section{Keluaran Hasil Penelitian}

a. Deskripsi Putusan Hakim terhadap Kasus Pertanahan; 
b. Revisi peraturan guna mengatasi sengketa pertanahan;

c. Sebagai bahan kajian kemungkinan dibentuk lembaga peradilan khusus pertanahan.

\section{E. Ruang Lingkup.}

Studi ini difokuskan pada jenis produk pelayanan pertanahan berupa sertipikat untuk Perorangan maupun Badan Hukum

Adapun faktor-faktor yang mempengaruhi difokuskan pada aspek obyek, subyek dan kelembagaan

a. $\quad$ Aspek Obyek meliputi segi yuridis dan segi fisik

1. Segi Yuridis meliputi :
a. data yuridis
b. proses administtrasi
c. hasil produk ( SK, Sertipikat)

2. Segi Fisik meliputi :
a. data fisik
b. peralatan teknis
c. produk (hasil ukur, gambar ukur)

b. Aspek Subyek meliputi penerima sertipikat Perorangan dan Badan Hukum Pemerintah maupun maupun Swasta

c. Aspek Kelembagaan difokuskan pada sistem pendaftaran tanah dan lembaga yang mempunyai kewenangan mengeluarkan produk (sertipikat)

\section{F. Metode Penelitian}

\section{Unit Analisis dan Responden penelitian}

Satuan unit analisis yang digunakan dalam penelitian ini adalah sengketa tanah berstatus sertipikat hak atas tanah yang kasusnya telah diputuskan oleh Pengadilan. Kasus ini dapat berupa sengketa tanah antara perorangan dengan perorangan, antara perorangan dengan badan hukum maupun antara badan hukum yang memperoleh hak atas tanah.

Populasi dalam penelitian ini adalah seluruh sengketa tanah berstatus sertipikat hak atas tanah yang kasusya telah diputuskan oleh Pengadilan. Populasi untuk seluruh propinsi tidak diketahui dengan pasti, oleh karena itu tim peneliti melakukan pendekatan dan asumsi bahwa populasi sengketa tanah ini hanya yang dilaporkan dan datanya tersedia di Kanwil BPN Propinsi. Selanjutnya dilakukan penelitian lebih mendalam dengan menggunakan teknik purposive sampling secara bertingkat di daerah Kabupaten/Kota.

Jenis data yang diperlukan dalam penelitian ini ada dua macam yaitu data sekunder dan data primer. Data sekunder terdiri dari dua jenis yaitu yang bersifat bahan pokok terkait sengketa tanah dan bersifat pendukung yang terkait dengan kondisi lingkungan/daerah yang diduga berpengaruh terhadap terjadinya sengketa tanah. Data sekunder tersebut sumber perolehannya di Kantor Wilayah BPN Propinsi, Kantor Pertanahan, dan sumber lain yang relevan. 
Data primer yang materi pokoknya berupa pendapat berkaitan dengan faktor penyebab terjadinya sengketa tanah, solusi yang telah dilakukan dan alternatif lain yang diusulkan maupun model lembaga pengadilan yang sesuai dengan sengketa tanah digali dari wawancara dengan pejabat terkait dengan sengketa tanah tersebut Responden untuk Propinsi adalah Kakanwil BPN Propinsi, Kabid HAT beserta Seksi terkait serta Kabid P \& PT beserta Seksi terkait. Responden untuk Kantor Pertanahan adalah Kakantah, Kasie HAT beserta Subsi terkait (Subsi PMP) serta Kasie P \& PT beserta Sub Seksi terkait .

Pengolahan dan analisis data dilakukan dengan metode deskriptif, meliputi :

2. Inventarisasi Data Sengketa Tanah

Data sengketa tanah yang diperoleh di kantor pertanahan dihimpun dan dikelompokkan menurut jenis kasus sengketa, pihak yang bersengketa, waktu/tahun penanganan serta putusan pengadilan.

\section{Pengolahan Data Kasus Tanah Per Kabupaten/Kota}

Berdasarkan hasil inventarisasi data di atas kemudian dipilih dua contoh kasus yang memenuhi kriteria sebagai berikut :

a. BPN/Kantor Pertanahan sebagai tergugat dan dinyatakan kalah dalam putusan hakim

b. Kasus perorangan vs perorangan dan Kasus perorangan vs badan hukum

c. Diprioritaskan kasus yang sudah inkracht dan sudah dieksekusi.

d. Analisis Kasus Sengketa Per Kabupaten/Kota

Analisis kasus sengketa kabupaten/kota didasarkan pada komparasi aspek legal yaitu peraturan dan pertimbangan hukum yang digunakan di tingkat Peradilan Tata Usaha Negara, Peradilan Umum dan Mahkamah Agung. Butir-butir yang dikomparasi antara lain dasar peraturan, pertimbangan hukum. Dalam analisis tersebut dikomparasi pula pendapat dan harapan nara sumber dan responden tentang produk hukum pengadilan tersebut.

\section{BAB II \\ TINJAUAN PUSTAKA}

\section{A. Gambaran Pola Permasalahan Pertanahan}


Meningkatnya kebutuhan tanah untuk keperluan pembangunan mengakibatkan meningkatnya sengketa pertanahan, maka untuk mempercepat penyelesaian sengketa pertanahan BPN mengeluarkan PMNA/KBPN No. 1 tahun 1999 tentang Tata Cara Penanganan Sengketa Petanahan. Tujuannya untuk mengatur tata cara penanganan sengketa secara terkoordinasi antar unit kerja di lingkungan BPN. Untuk itu dibentuk Sekretariat Penanganan Sengketa Pertanahan yang bertanggung jawab kepada Deputi Bidang Hak-Hak Atas Tanah (sekarang Deputi Bidang Pengkajian dan Huku Pertanahan Direktorat Pengurusan Hak-Hak Atas Tanah) dan Tim Kerja Pengolah Sengketa Pertanahan.

Ketua dan Penanggung Jawab ada pada Direktur Pengadaan Tanah Instansi Pemerintah. Sedangkan anggotanya antara lain :

- Kasubdit Penyelesaian Sengketa Hukum Dit PTIP,

- Kasubdit Penyelesaian Sengketa Hukum Dit Pengurusan Hak Tanah,

- Kasubdit Ganti Rugi dan Penyelesaian Masalah Dit PPT,

- Kasubdit Pendaftaran Tanah Dit Pendaftaran Hak Atas Tanah dan

- Kabag TU Pimpinan Biro Tata Usaha BPN.

Adapun Tim Kerja Pengolah Sengketa Pertanahan dibentuk untuk setiap sengketa pertanahan yang perlu ditangani secara koordinatif dengna susunan keanggotaan berasal dari unit-unit kerja di BPN berdasarkan fungsi unit kerja yang bersangkutan dan kemampuan/keahlian atau pengalaman kerja pejabat yang bersangkutan.

Untuk Tingkat Propinsi, penanganan penyelesaian sengketa pertanahan ditugaskan kepada Kepala Bidang Hak Atas Tanah yang dibantu oleh satu atau beberapa tim sesuai dengan klasifikasi masalahnya, demikian juga untuk tingkat Kabupaten/Kota ditugaskan kepada Kepala Seksi Hak Atas Tanah.

Penyelesaian dari kasus-kasus pertanahan kemudian menggunakan jalur hukum yaitu melalui lembaga peradilan. Ada beberapa jenis masalah yang ditangani BPN sampai saat ini dapat dipilah menjadi beberapa kelompok antara lain :

1. Masalah yang berkaitan dengan tanah perkebunan

2. Masalah Permohonan Hak Atas Tanah Yang Berkaitan dengan Kawasan Hutan

3. Masalah yang Berkaitan dengan Pelaksanaan Putusan Pengadilan

4. Masalah Permohonan Pendaftaran yang Berkaitan dengan Tumpang Tindih Hak atau Sengketa Batas

5. Masalah yang Betkaitan dengan Pendudukan Tanah dan/atau Tuntutan Ganti Rugi Masyarakat atas Tanah -tanah Yang Telah Dibeli/dibebaskan oleh Pengembang untuk Perumahan/Perkantoran.

6. Masalah Yang Berkaitan Dengan Klaim sebagai Tanah Ulayat

7. Masalah Yang Berkaitan dengan Tukar Menukar Tanah Bengkok Desa yang Telah Menjadi Kelurahan.

8. Masalah lain yang bersifat insidentil seperti masalah penolakan perpanjangan izin lokasi.

9. Masalah waris

10. dll.

Sengketa yang sudah diputus di PTUN, pada umumnya diteruskan ke Peradilan Umum. Hal ini dimungkinkan dalam pasal 55 UU No. 5 tahun 1986 dimana dinyatakan bahwa suatu keputusan TUN yang ada kaitannya dengan suatu perbuatan Onrechtmatige Overheidsdaad (OOD) yang menjadi wewenang Peradilan Umum maka dengan mengingat adanya tenggang waktu pengajuan gugatan dalam sengketa TUN, gugatan harus diajukan terlebih dulu ke PTUN dan diperiksa/diputus sampai tuntas. 
Setelah itu barulah dapat diajukan gugatan OODnya ke Peradilan Umum yang berwenang. Dengan demikian tidak diperkenankan kedua macam gugatan itu berjalan bersamaan untuk menghindari putusan yang saling bertentangan antara kedua Pengadilan tersebut yang mempunyai kompetensi absolute masing. Kompetensi peradilan ini juga diperkuat oleh SE MA tertanggal 14 Oktober 1993 Nomor 223/Td.TUN/X/1993.

Dimungkinkannya suatu perkara untuk diperiksa di Peradilan TUN dan Peradilan Umum berakibat diabaikannya prinsip-prinsip yang dianut dalam pelaksanaan Badan Peradilan di Indonesia yaitu sederhana, cepat dan murah sebab dengan pemeriksaan suatu perkara (sengketa pertanahan) oleh 2 badan peradilan selain memmerlukan waktu yang relative lama, biaya besar juga akan sangat mempengaruhi kinerja pelayanan pertanahan dan kepastian hukum.

Dalam hal kompetensi peradilan Philipus M. Hadjon berpendapat dalam KUHP terdapat kemungkinan untuk menggabungkan perkara pidana dan perkara perdata, apakah ada kemungkinan menggabungkan perkara perdata dengan sengketa TUN atau perkara pidana dengan sengketa TUN dalam hokum acara Peradilan Tata Usaha Negara hendaknya menjadi suatu kajian dalam pengembangan hukum administrasi di Indonesia. Mungkin sudah saatnya mulai dipikirkan kemungkinan integrasi badan-badan pengadilan dalam usaha lebih meningkatkan perlindungan hokum bagi rakyat Indonesia.

Terjadinya sengketa pertanahan tidak terlepas dari proses dalam penyelenggaraan pendaftaran tanah dan dikeluarkannya sertipikat sebagai alat bukti hak.

Pasal 32 ayat 1 PP No. 24 tahun 1997 disebutkan sertipikat berlaku sebagai alat bukti yang kuat. Artinya sertipikat merupakan alat bukti sempurna. Sepanjang tidak ada bukti sebaliknya, maka data fisik dan data yuridis yang tercantum dalam sertipikat harus diterima sebagai data yang benar.

Sertipikat tanah diterbitkan atau pencatatan peralihan haknya dilakukan oleh Kepala Kantor Pertanahan. Kepala Kantor Pertanahan diangkat oleh Kepala Badan Pertanahan Nasional (BPN). Menurut UU No. 5 tahun 1986 pasal 6.1 bahwa tergugat adalah Badan atau Pejabat Tata Usaha Negara yang mengeluarkan keputusan berdasarkan wewenang yang ada padanya atau yang dilimpahkan kepadanya, yang digugat oleh orang atau badan hukum perdata.

Irawan Soerodjo berpendapat bahwa sertipikat tanah merupakan refleksi dari suatu penetapan tertulis sehingga setiap adanya gugatan yang berhubungan dengan sertipikat tanah menjadi kompetensi Peradilan Tata Usaha Negara.

\section{B. Sejarah Pendaftaran Tanah}

Pendaftaran Tanah semula dikenal dengan istilah Kadaster (cadastre, bahasa Perancis,kadaster bahahasa Jerman) berasal dari bahasa latin capitastrum yang berarti suatu register atau capita atau unit yang diadakan untuk pajak tanah Romawi dan berarti suatu istilah teknis untuk record (rekaman), yang menggambarkan tentang luas, nilai, subyek, atas hak pada suatu bidang tanah. Pengertian kadaster selanjutnya berkembang yaitu :

- Sebagai tugas (functie) yang tertentu yang harus diselenggarakan oleh Pemerintah

- Sebagai badan (organ) pemerintah yang menjalankan tugas yang tertentu itu.

\section{Fase VOC}


VOC yang didirikan pada tahun 1602 disamping menerima hak untuk berdagang di Indonesia juga menerima hak untuk menjalankan kekuasaan yang berdaulat atas daerah-daerah yang dikuasainya dengan kekuatan senjata. Adanya hak tersebut menjadikan VOC memberikan tanah-tanah yang terletak di daerah kekuasaannya kepada bekas pegawai-pegawai VOC yang menetap di daerah kekuasaannya juga kepada orang-orang Belanda yang sengaja didatangkan dari negeri Belanda sebagai transmigran. VOC pada tahun 1620 mengeluarkan suatu plakat atau maklumat yang merupakan dasar bagi penyelenggaraan Kadaster dan pendaftaran hak di Hindia Belanda. Plakat tersebut menetapkan bahwa Bailluw dan Schepen harus menyelenggarakan pendaftaran segala pekarangan dan pohon buah-buahan yang telah diberikan VOC serta pencatatan nama-nama pemiliknya. Pendaftaran ini merupakan Kadaster dalam arti kuno karena dilakukan tanpa didasarkan pada peta-peta tanah.

Pada tanggal 23 Juli 1680, VOC mengeluarkan plakat yang mengatur mengenai susunan dan tugas Dewan Heemraden. Pasal 16 plakat tersebut menetapkan bahwa Dewan Heemraden harus dengan segera membuat suatu peta umum dari tanah-tanah yang terletak dalam wilayah kerjanya yang pada setiap petanya dicatat luas dari tiap-tiap tanah serta nama pemiliknya. Plakat ini merupakan dasar bagi penyelenggaraan kadaster dalam arti modern. Tujuan penyelenggaraan kadaster disini adalah untuk pemungutan pajak tanah dan memberikan jaminan kepastian hukum atas tanah.

\section{Fase Ahli Ukur Pemerintah}

Dalam keputusannya pada tanggal 18 Januari 1837 Nomor 3 menginstruksikan kepada para ahli ukur untuk :

a. Menyimpan dan memelihara peta-peta tanah yang telah ada atau peta-peta tanah yang dibuat oleh para ahli ukur tanah sebelum berlakunya instruksi tersebut dan membuat peta-peta tanah dari bidang-bidang tanah yang belum diukur dan di peta.

b. Menyelenggarakan daftar-daftar yang terdiri dari :

- Daftar tanah, yaitu daftar dimana tiap-tiap bidang tanah di daftar menurut nomor atau huruf yang diberikan pada bidang-bidang tanah yanh dipetakan

- Daftar dari semua peta seperti peta kasar dan peta-peta lain

- Daftar dari hasil pengukuran dan penaksiran

c. Memberikan Landmeterskennis (surat keterangan pendaftaran tanah).

Pasal 12 Stb 1873 Nomer 3 menyatakan jika para ahli ukur menganggap perlu adanya pengukuran dan pemetaan bidang tanah, maka pembeli atau penjual wajib meminta pengukuran dan pemetaan bidang tanah yang bersangkutan kepada ahli ukur atas biaya sendiri. Tanpa pengukuran dan pemetaan bidangbidang tanah itu ahli ukur dapat menolak memberikan landmeterskennis.

\section{Fase Pendaftaran Tanah}

Pemerintah Hindia Belanda pada tahun 1871 membentuk suatu komisi yang mempelajari perlu tidaknya penataan kembali kadaster. Kemudian dikeluarkan Stb 1875 No. 183 yang manyatakan bahwa bidangbidang tanah yang harus diukur dan dipeta adalah :

- Bidang tanah yang dipunyai oleh orang atau badan hokum dengan sesuatu hak

- Bagian-bagian dari bidang tanah hak jika bagian-bagian dari bidang tanah itu terpisah oleh batas alam atau jika bagian-bagian tanah itu mempunyai tanaman yang berbeda-beda 
- Bagian-bagian dari jalan dan perairan yang mempunyai nama sendiri

- Bagian-bagian dari bidang tanah yang terletak di seksi lain.

Bidang-bidang tanah yang digunakan oleh pemegang haknya akan memperoleh nomor kadaster pada peta kadaster.

Setelah peta-peta Kadaster dari suatu daerah Kadaster selesai dibuat, maka harus disusun dalam tata usaha Kadaster (Kadaster boekhouding) menurut contoh dengan daftar yang ditetapkan dalam Bijblad Nomor 3308.

Tugas-tugas yang diberikan kepada Kadaster dalam Stb 1879 No. 164 adalah sebagai berikut :

- Membuat peta-peta dari ibukota propinsi (gewest)dan karesidenan (afdeling) di Jawa dan Madura.

- Membuat peta dari pulau Jawa dan madura (kecuali Karesidenan Yogya, Surakarta, kabupaten Madura dan Sumenep) dengan ketentuan bahwa batas-batas bidang tanah yang dipetakan pada peta-peta tersebut hanya Hak Eropa atau Hak Agrarisch Eigendom

- Melakukan tugas-tugas yang diberikan kepada para ahli ukur pemerintah sebagaimana dimaksud dalam Stb 1837 No. 3

- Memelihara peta-peta yang telah dibuat dalam rangka statiestiek opname

Penyelenggaraan Kadaster di daerah-daerah dilakukan oleh bewaarder sebagai Kepala Kantor Kadaster atau oleh seorang pejabat Kadaster lain yang menjalankan fungsi bewaarder.

\section{Ordonansi Balik Nama}

Pada tanggal 21 April 1834 diberlakukan Stb 1834 No. 27 tentang Bea Balik Nama(selanjutnya disebut Ordonansi Balik Nama).

Pokok-pokok dari Pendaftaran hak yang diatur dalam Ordonansi balik Nama adalah :

- Setiap peralihan Hak harus didaftar pada pejabat Balik Nama

- Pembuatan akta pendafataran peralihan hak atau akta balik nama oleh pejabat balik nama

- Asli akta balik nama disimpan oleh pejabat pembantu dalam 2 bundel terpisak, yaitu bundle koopbriven dan bundel hypotheekbrieven, sedangkan kepada yang bersangkutan diberikan salinan sah (grosse) akta balik nama

- Pejabat Balik Nama dan pejabat pembantu bertanggung jawab secara pribadi atas kerugian yang timbul akibat kelalaian mereka dalam melaksanakan kewajiban yang ditetapkan dalam ordonansi balik nama

- Surat keterangan pendaftaran tanah (landmeterskennis), dan surat ukur pemisahan

Jika terjadi Jual Beli, maka pembeli harus hadir untuk menerangkan bahwa ia telah menerima penyerahan tersebut, dan terjadinya peralihan hak setelah akta balik nama dibuat, sehingga pendaftaran merupakan syarat mutlak bagi peralihan hak. Akta jual beli hanya merupakan dasar hukum dari penyerahan. Sistem ini memperoleh bentuk yang tetap dan berlaku hingga sekarang.

\section{Peraturan Pemerintah Nomor 10 tahun 1961}

Untuk menjamin kepastian hukum dari hak-hak atas tanah, maka UUPA mengharuskan Pemerintah untuk mengadakan pendaftaran tanah di seluruh wilayah Republik Indonesia. Dalam pasal 2 ditentukan bahwa pendaftaran tanah meliputi 2 hal yaitu : 
- Pengukuran dan pemetaan-pemetaan tanah serta menyelenggarakan tata usahanya

- Pendaftaran hak serta peralihannya dan pemberian surat tanda bukti hak yang berlaku sebagai alat pembuktian yang kuat.

Pendaftaran dilakukan desa demi desa dan untuk menyelenggarakan tata usaha pendaftaran tanah diadakan

- Daftar tanah

- Daftar nama

- Daftar buku tanah

- Daftar surat ukur

Agar segala yang didaftarkan dalam daftar buku tanah tetap sesuai dengan keadaan yang sebenarnya maka perubahan yang terjadi atas sesuatu hak harus pula didaftarkan. Maka setiap perjanjian yang bermaksud memindahkan hak atas tanah, memberikan hak sesuatu hak baru atas tanah, menggadaikan tanah atau meminjam uang dengan hak atas tanah sebagai jaminan harus dibuktikan dengan suatu akta yang dibuat oleh dan di hadapan seorang pejabat yang ditunjuk. Pejabat tersebut diwajibkan mengirimkan akta tersebut kepada Kepala Kantor Pendaftaran Tanah untuk didaftarkan dalam daftar buku tanah yang bersangkutan.

\section{PP No 24 tahun 1997}

Penyelenggaraan Pendaftaran Tanah berdasarkan P No. 10 tahun 1961 dipandang tidak lagi sepenuhnya mendukung tercapainya hasil yang nyata pada pembangunan nasional sehingga perlu disempurnakan. Pemerintah memandang perlu untuk membuat suatu aturan yang lebih lengkap yang dapat memenuhi kebutuhan masyarakat dan menjamin kepastian hokum dan akhirnya Pemerintah mengundangkan PP No. 24 tahun 1997 tentang Pendaftaran Tanah.Peraturan Pelaksanaannya diatur dengan Peraturan Menteri Negara Agraria/Kepala Badan Pertanahan Nasional No. 3 tahun 1997.

Pasal 64 ayat 1 menyatakan bahwa dengan berlakunya Peraturan Pemerintah ini maka semua peraturan perundang-undangan sebagai pelaksanaan PP No. 10 tahun 1961 masih tetap berlaku sepanjang tidak bertentangan atau di ubah atau diganti dengan PP ini. Dalam PP No. 24 tahun 1997 yang menyempurnakan PP No. 10 tahun 1961 ini, tujuan dan stelsel Pendaftaran Tanah tetap dipertahankan yang pada hakekatnya sudah ditetapkan dalam UUPA yaitu pendaftaran tanah diselenggarakan dalam rangka memberikan jaminan kepastian hukum di bidang pertanahan dan bahwa stelsel yang dianut adalah stelsel negative tetapi mengandung unsure positif, karena akan menghasilkan surat-surat tanda bukti hak yang berlaku sebagai alat pembuktian yang kuat.

Pendaftaran Tanah tetap dilaksanakan melalui dua cara yaitu secara sistematik yang meliputi wilayah satu desa atau kelurahan, atau sebagiannya yang terutama dilakukan atas prakarsa Pemerintah; dan secara sporadic yaitu pendaftaran mengenai bidang-bidang tanah atas permintaan pemegang atau penerima hak yang bersangkutan secara individual atau massal.

Pendaftaran Tanah diselenggarakan antara lain untuk menyediakan informasi kepada pihak-pihak yang berkepentingan, agar dengan mudah dapat memperoleh data yang diperlukan dalam rangka melaukan perbuatan hukum mengenai bidang-bidang tanah atau satuan-satuan rumah susun yag sudah terdaftar. 
Penyajian data tersebut dilaksanakan oleh Kantor Pertanahan Kabupaten/Kota seksi tata usaha pendaftaran tanah, yang dikenal sebagai daftar umum, yang terdiri atas :

- Peta pendaftaran yaitu peta yang menggambarkan bidang atau bidang-bidang tanah untuk keperluan pembukuan tanah.

- Daftar tanah yaitu dokumen dalam bentuk daftar yang memuat identitas bidang tanah dengan suatu sistim penomoran

- Surat ukur yaitu dokumen yang memuat data fisik suatu bidang tanah dalam bentuk peta dan uraian yang diambil datanya dari peta pendaftaran.

- Buku tanah yaitu dokumen dalam bentuk daftar yang memuat data yuridis dan data fisik suatu obyek pendaftaran tanah yang sudah ada haknya

- Daftar nama yaitu dokumen dalam bentuk daftar yang memuat keterangan mengenai penguasaan tanah dengan suatu hak atas tanah atau hak pengelolaan dan mengenai pemilikan Hak Milik Atas Satuan Rumah Susun. Oleh orang perseorangan atau badan hukum tertentu.

\section{Pengertian Pendaftaran Tanah}

Pasal 1 butir 1 PP No. 24 tahun 1997 menyebutkan bahwa Pendaftaran Tanah adalah rangkaian kegiatan yang dilakukan oleh Pemerintah secara terus-menerus, berkesianmbungan dan teratur, meliputi : pengumpulan, pengolahan, pembukuan, dan penyajian serta pemeliharaan data fisik dan data yuridis, dalam bentuk peta dan daftar, mengenai bidang-bidang tanah dan satuan-satuan rumah susun , ternasuk pemberian surat tanda bukti haknya bagi bidang-bidang tanah yang sudah ada haknya dan hak milik satuan rumah susun serta hak-hak tertentu yang membebaninya.

Pendaftaran tanah tersebut pada dasarnya merupakan kewajiban Pemerintah yang telah diatur sebelum berlakunya peraturan pemerintah Nomor 24 Tahun 1997, yaitu baik dalam UUPA maupun Peraturan Pemerintah nomor 10 Tahun 1961.

\section{Prinsip Pendaftaran Tanah}

Menurut pasal 2 PP No. 2 tahun 1997, Pendaftaran Tanah dilaksanakan berdasarkan asas sederhana, aman, terjangkau, mutakhir dan terbuka. Asas sederhana dalam pendaftaran tanah tersebut dimaksudkan agar ketentuan-ketentuan pokok maupun prosedurnya dengan mudah dapat dipahami oleh pihak-pihak yang berkepentingan, terutama para pemegang hak atas tanah. Sedangkan asas aman dimaksudkan untuk menunjukkan bahwa pendaftaran tanah perlu diselenggarakan secara teliti dan cermat sehingga hasilnya dapat memberikan jaminan kepastian hukum sesuai dengan tujuan pendaftaran tanah itu sendiri. Asas terjangkau dimaksudkan bagi pihak-pihak yang memerlukan khususnya dengan memperhatikan kebutuhan dan kemampuan golongan ekonomi lemah.

Pelayanan yang diberikan dalam rangka penyelenggaraan pendaftaran tanah harus bisa terjangkau oleh para pihak yang memerlukan. Asas mutakhir dimaksudkan kelengkapan yang memadai dalam pelaksanaannya dan kesinambungan dalam pemeliharaan datanya. Data yang tersedia harus menunjukkan keadaan yang mutakhir. Untuk itu perlu diikuti kewajibanmendaftar dan pencatatan perubahan-perubahan yang terjadi di kemudian hari. Asas mutakhir menuntut dipeliharanya data pendaftaran tanah secara terus-menerus dan berkesinambungan, sehingga data yang tersimpan di Kantor Pertanahan selalu sesuai dengan keadaan nyata di lapangan, dan masyarakat dapat memperoleh keterangan mengenai data yang benar setiap saat. 
Namun demikian penerapan asas dalam pendaftaran tanah tersebut perlu dikaji ulang, khususnya terhadap asas murah dan sederhana karena akan berdampak bagi produk yang dihasilkan dalam rangka memberikan jaminan kepastian hukum dari hak-hak atas tanah itu sendiri. Sebab dalam rangka pendaftaran tanah untuk pelaksanaan pengukuran agar hasil yang diperoleh lebih akurat baik data fisik maupun data yuridis atas bidang-bidang tanah yang diukur, diperlukan waktu yang cukup panjang dengan biaya yang relatif tinggi, sehingga penyajian data nantinya diharapkan dapat memberikan jaminan kepastian hukum atas bidang-bidang tanah tersebut bagi pihak-pihak yang berkepentingan yang memerlukan informasi data tanah yang diperlukan untuk suatu keperluan mengenai bidang-bidang tanah dan satuan-satuan rumah susun yang sudah terdaftar.

\section{Tujuan Penyelenggaraan Pendaftaran tanah}

Dalam Peraturan Pemerintah Nomor 24 Tahun 1997 yang menyempurnakan Peraturan Pemerintah Nomor 10 Tahun 1961 ini, tetap dipertahankan tujuan diselenggarakannya pendaftaran tanah, yang pada hakekatnya sudah ditetapkan dalam pasal 19 UUPA, yaitu bahwa pendaftaran tanah diselenggarakan dalam rangka menjamin kepastian hukum di bidang pertanahan (rechtskadaster atau legal cadastre).

Secara garis besar rincian tujuan pendaftaran tanah seperti yang dinyatakan dala pasal 3 Peraturan Pemerintah Nomor 24 Tahun 1997, yaitu:

a. untuk memberikan kepastian hukum dan perlindungan hukum kepada pemegang hak atas suatu bidang tanah, satuan rumah susun dan hak-hak lain yang terdaftar, agar dengan mudah dapat membuktikan dirinya sebagai pemegang hak yang bersangkutan. Untuk itu kepada pemegang haknya diberikan sertipikat sebagai surat tanda bukti haknya.

b. Untuk menyediakan informasi kepada pihak-piak yang berkepentingan, termasuk Pemerintah, agar dengan mudah dapat memperoleh data yang diperlukan jika mengadakan perbuatan hukum mengenai bidang-bidang tanah dan satuan-satuan rumah susun yang sudah terdaftar. Untuk penyajian data tersebut dilaksanakan oleh seksi tata usaha pendaftaran tanah Kantor Pertanahan Kabupaten/Kotamadya yang dikenal sebagai daftar umum, yang terdiri atas peta pendaftaran tanah, daftar tanah, surat ukur, buku tanah dan daftar nama.

\section{Sistem Pendaftaran Tanah}

Sistem pendaftaran yang digunakanadalah system pendaftaran hak (registration of titles), sebagaimana digunakan dalam penyelenggaraan pendaftaran tanah menurut Peraturan Pemerintah Nomor 10 Tahun 1961. Hal tersebut tampak dengan adanya buku tanah sebagai dokumen yang memuat data yuridis dan data fisik yang dihimpun dan disajikan serta diterbitkannya sertipikat sebagai syrat tanda bukti hak atas tanah yang didaftar.

Sebagaimana yang diamanatkan dalam pasal 19 UUPA maka untuk memberikan jaminan kepastian hukum atau suatu bidang tanah, pemerintah wajib menyelenggarakan pendaftaran tanah. Peran pemerintah dalam hal ini Badan Pertanahan Nasional sangat besar dalam menyelenggarakan Pendaftaran Tanah baik secara sistematik maupun sporadik, hanya saja dalam pendaftaran tanah secara sporadic maka bobot proaktif adalah terletak pada pemegang hak atas tanah.

Hak atas tanah yaitu Hak Milik, Hak Guna bangunan, Hak Pakai, Hak Pengelolaan, tanah wakaf dan Hak Milik Atas satuan Rumah Susun didaftar dengan membukukannya dalam buku tanah yang memuat data 
yuridis dan data fisik bidang tanah yang bersangkutan dan sepanjang ada surat ukurnya maka dicatat pula status haknya pada surat ukur tersebut. Pembukuan dalam dalam buku tanah serta pencatatannya pada surat ukur tersebut merupakan bukti, bahwa hak yang bersangkutan beserta pemegang haknya dan bidang tanahnya yang diuraikan dalam surat ukur telah didaftar. Menurut pasal 31 Peraturan Pemerintah Nomor 24 Tahun 1997 untuk kepentingan pemegang hak yang bersangkutan diterbitkan sertipikat tanah sesuai dengan data fisik dan data yuridis yang telah didaftar dalam buku tanah.

\section{Stelsel Pendaftaran Tanah}

Stelsel pendaftaran tanah yang digunakan dalam Peraturan Pemerintah Nomor 24 Tahun 1997 adalah sama seperti yang digunakan dalam pendaftaran tanah menurut Peraturan Pemerintah Nomor 10 Tahun 1961, yaitu stelsel negatif yang mengandung unsur positif karena akan menghasilkan surat-surat tanda bukti hak yang berlaku sebagai alat pembuktian yang kuat sebagaimana dinyatakan dalam UUPA, yaitu:

a. Pasal 19 ayat (2) huruf $\mathrm{c}$;

b. Pasal 23 ayat (2);

c. Pasal 32 ayat (2), dan

d. Pasal 38 ayat (2) UUPA.

Dalam stelsel ini, pihak-pihak yang merasa mempunyai sesuatu hak dapat melakukan gugatan terhadap pihak-pihak yang namanya tercantum dalam sertipikat. Hanya saja dalam Peraturan Pemerintah Nomor 24 Tahun 1997, pihak yang merasa mempunyai suatu hak atas tanah, dubatasi hanya dalam jangka waktu 5 (lima) tahun sejak diterbitkannya sertipikat tanah untuk melakukan gugatan dalam rangka mempertahankan haknya.

\section{BAB III \\ PENDEKATAN PENELITIAN}

\section{A. Kerangka Pemikiran}

Penelitian ini dilandasi pada fakta meningkatnya sengketa pertanahan yang ditangani melalui lembaga peradilan, baik Pengadilan Negeri, Pengadilan Tinggi maupun Mahkamah Agung Dalam proses peradilan tersebut pejabat/BPN khususnya Kantor Pertanahan kabupaten/Kota sering menjadi tergugat dan dalam prosesnya dikalahkan. Meningkatnya sengketa pertanahan tersebut secara umum disebabkan faktor internal yang bersumber dari pelayanan pertanahan dan faktor eksternal yang bersumber dari masyarakat dan instansi terkait seperti Desa/Kelurahan, Camat, PPAT, KP-PBB dsb.

Pemikiran yang kemudian berkembang bahwa instansi pertanahan sebagai instansi yang diberi tugas dan wewenang menerbitkan produk hukum berupa sertipikat hak atas tanah memerlukan jaminan dari lembaga peradilan tentang kepastian hukumnya. Dalam prakteknya kasus sengketa pertanahan yang diputuskan di lembaga peradilan TUN sering berbeda dengan lembaga peradilan perdata. Bahkan putusan perdata di Pengadilan Negeri sering berbeda dengan putusan di Pengadilan Tinggi. Selanjutnya kasasi Mahkamah Agung juga sering berbeda dengan Pengadilan Tinggi dan atau Pengadilan Negeri. 
Perbedaan tersebut umumnya disebabkan dua hal pokok :

Pertama, adanya perbedaan persepsi dalam menggunakan peraturan yang menjadi dasar penafsiran terhadap suatu kasus pertanahan di lembaga peradilan.

Kedua, putusan hukum di lembaga peradilan tidak mengacu kepada Hukum Tanah Nasional, baik UUPA maupun peraturan pelaksanaannya.

Terhadap penyebab pertama, alternatif pemecahannya adalah dengan mengupayakan agar Hukum Tanah Nasional dengan berbagai peraturan pelaksanaannya dapat digunakan sebagai acuan pertimbangan hukum dalam keputusan pengadilan. Alternatif ini perlu diikuti dengan sosialisasi peraturan pertanahan seperti KADARKUM, koordinasi dengan instansi terkait lembaga peradilan termasuk kepolisian dan kejaksaan serta pendidikan dan pelatihan tentang penanganan sengketa pertanahan.

Terhadap penyebab kedua, alternatif pemecahannya adalah dengan membentuk peradilan khusus yang menangani masalah dan sengketa pertanahan yang mengacu pada Hukum Tanah Nasional.

Penelitian ini tidak diarahkan pada perubahan sistem pendaftaran tanah yang saat ini masih menggunakan asas negatif bertendens positif menjadi pendaftaran tanah berasas posistif, namun klausul-klausul dalam peraturan pendaftaran tanah yang menuju arah positif perlu diperkuat sehingga dapat dijadikan sebagai acuan dalam menangani sengketa pertanahan di lembaga peradilan,

Maka implikasinya, ketentuan dalam Hukum Tanah Nasional maupun peraturan pelaksanaannya, khususnya PP No 24 Tahun 1997 tentang Pendaftaran Tanah serta Instruksi Menteri Negara Agraria/Kepala BPN No. 3 Tahun 1998 tentang Peningkatan Efisiensi Pelayanan Pertanahan memerlukan penyempurnaan sehingga jaminan kepastian hukum dengan diterbitkannya sertipikat hak atas tanah dapat diberlakukan pula di lembaga peradilan.

Secara umum kerangka pemikiran penelitian ini disajikan pada Gambar 3-1.

\section{B. Kerangka Kerja}

Penelitian ini dilakukan secara swakelola oleh para peneliti Puslitbang dari berbagai latar belakang pendidikan serta tingkat pengetahuan hukum yang beragam. Oleh karena itu perlu dikembangkan kerangka kerja yang berguna untuk memberi pedoman pelaksanaan penelitian. Kerangka kerja tersebut (Gambar 3.2) meliputi beberapa tahap, yaitu:.

a. Tahap Penyusunan TOR dan Riset Disain

b. Tahap Uji Coba Instrumen (Penelitian Pendahuluan) di Provinsi Jawa Barat.

c. Tahap penelitian lengkap di tujuh propinsi Jawa dan Luar Jawa.

d. Tahap Penyusunan Laporan Draft Akhir

e. Tahap Penyusunan Laporan Akhir Penelitian

c. Definisi Operasional 
a. Keputusan hakim adalah suatu penetapan tertulis yang dikeluarkan oleh Pengadilan Negeri, Pengadilan Tinggi dan Mahkamah Agung.

b. Sengketa Pertanahan adalah perbedaan pendapat mengenai:

- keabsahan suatu hak

- pemberian hak atas tanah

- pendaftaran hak atas tanah termasuk peralihannya dan penerbitan tanda bukti haknya

c. Pihak-Pihak yang Berkepentingan adalah pihak-pihak yang merasa mempunyai hubungan hak dengan bidang tanah tertentu atau pihak lain yang kepentingannya terpengaruh oleh status hak tersebut.

d. Peradilan Umum adalah pelaksanaan kekuasaan kehakiman dalam perkara perdata atau pidana yang dilaksanakan oleh pengadilan Negeri dan Pengadilan Tinggi.

e. Peradilan Tata Usaha Negara adalah salah satu pelaksanaan kekuasaan kehakiman bagi rakyat pencari keadilan terhadap sengketa Tata Usaha Negara.

f. Keputusan Tata Usaha Negara adalah suatu penetapan tertulis yang dikeluarkan oleh Badan atau Pejabat tata Usaha Negara yang berisi tindakan hukum Tata Usaha Negara berdasarkan peraturan perundang-undangan yang berlaku, yang bersifat konkrit, individual dan final yang menimbulkan akibat hukum bagi seseorang atau badan hukum perdata.

g. Alat Bukti adalah segala sesuatu yang dapat meneguhkan atau membantah ada/tidak adanya suatu hak.

h. Pendaftaran tanah adalah rangkaian kegiatan yang dilakukan oleh pemerintah secara terus menerus, berkesinambungan dan teratur, meliputi pengumpulan, pengolahan, pembukuan, dan penyajian serta pemeliharaan data fisik dan data yuridis dalam bentuk peta dan daftar mengenai bidang-bidang tanah dan satuan-satuan rumah susun, termasuk pemberian surat tanda bukti haknya bagi bidang-bidang tanah yang sudah ada haknya dan Hak Milik atas satuan rumah susun serta hak-hak tertentu yang membebaninya.

i. Data fisik adalah keterangan mengenai letak, batas dan luas bidang dan satuan rumah susun yang didaftar, termasuk keterangan mengenai adanya bangunan atau bagian bangunan diatasnya.

j. Data yuridis keterangan mengenai status hukum bidang tanah dan satuan rumah susun yang didaftar, pemegang haknya dan hak pihak lain serta beban-beban lain yang membebaninya.

k. Sertipikat adalah surat tanda bukti hak sebagaimana dimaksud dalam Pasal 19 ayat 2 huruf c UUPA untuk hak atas tanah, hak pengelolaan, tanah wakaf, hak milik atas satuan rumah susun dan hak tanggungan yang masing-masing sudah dibukukan dalam buku tanah yang bersangkutan.

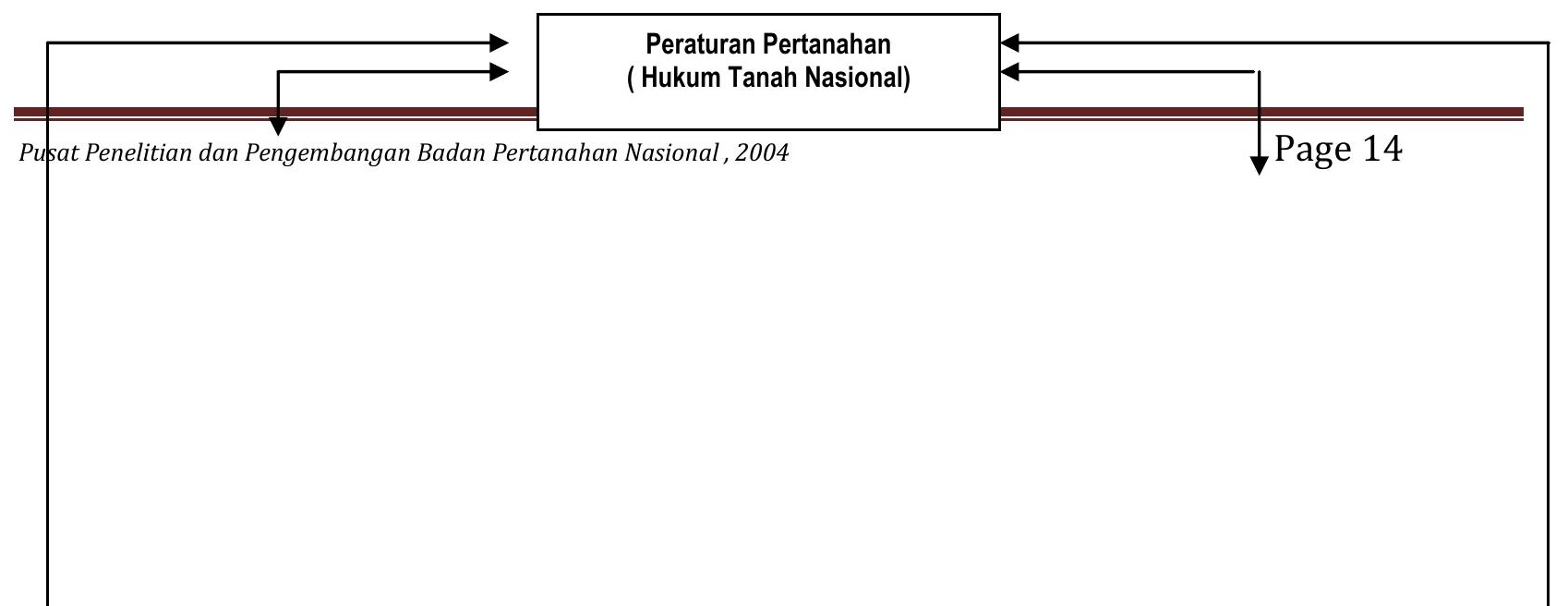



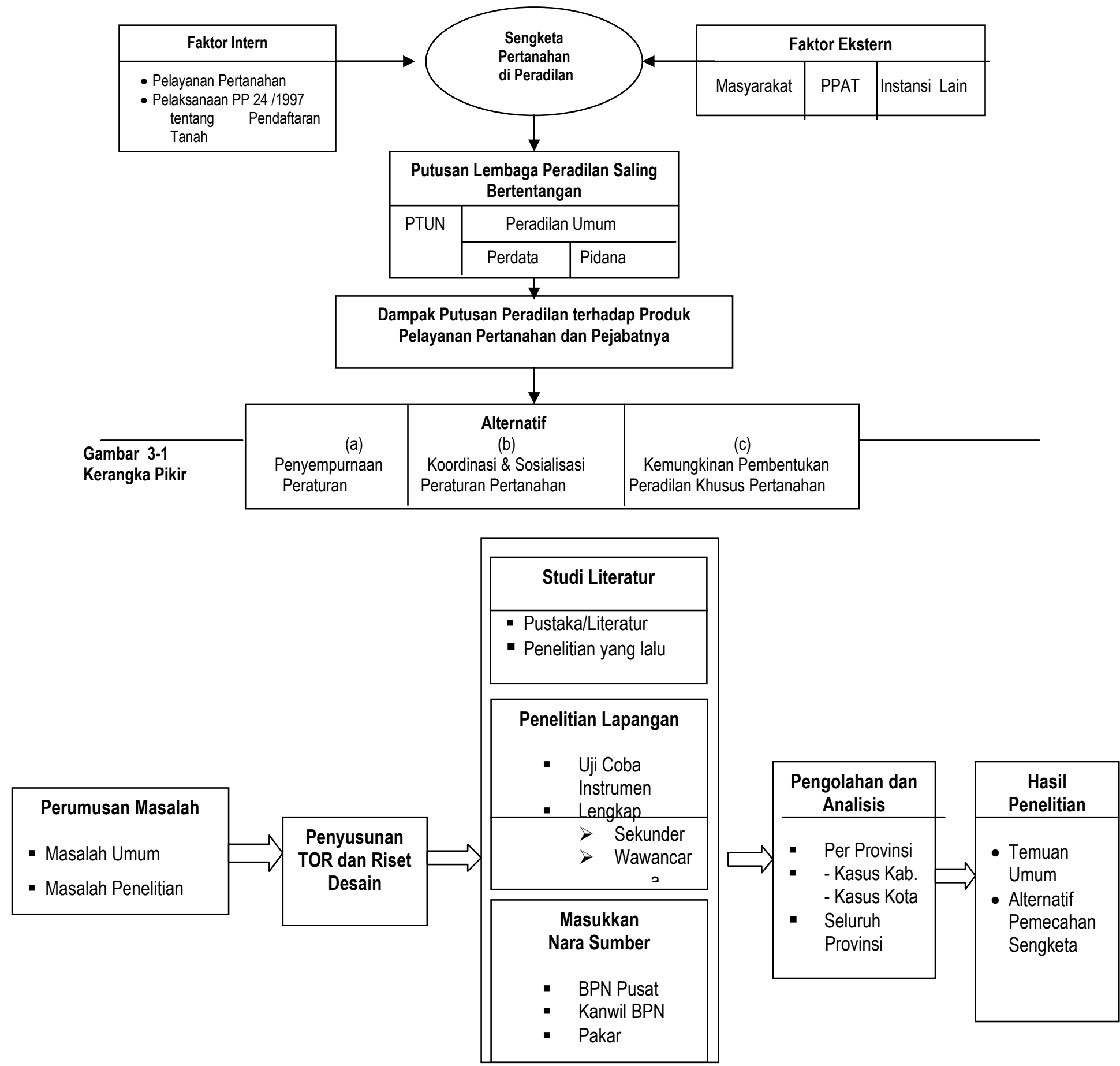

Gambar 3.2 


\section{BAB IV \\ HASIL PENELITIAN DAN PEMBAHASAN}

Sebagaimana diutarakan dalam bab pendahuluan, penelitian ini bertujuan mengkaji jenis produk pelayanan yang sering menimbulkan sengketa dan faktor-faktor yang menjadi penyebabnya, bentuk putusan peradilan terkait dengan produk pelayanan yang saling bertentangan serta solusi untuk mengurangi/menghindari gugatan terhadap produk pelayanan pertanahan. Untuk itu dalam bab ini terlebih dahulu akan diuraikan jenis pelayanan pertanahan yang sering diajukan ke Pengadilan.

\section{A. Jenis Sengketa Pertanahan yang Diperkarakan di Pengadilan.}

Dewasa ini masalah pertanahan yang diperkarakan di pengadilan terus meningkat sehingga mempengaruhi kinerja BPN. Produk yang dihasilkannya yaitu sertipikat yang seharusnya memberikan kepastian hukum dan perlindungan hukum yang pada gilirannya menumbuhkan rasa aman kepada masyarakat sebagaimana yang dijanjikan kepada masyarakat dalam Pasal 19 UUPA dan Peraturan pemerintah Nomor 24 Tahun 1997 jo Peraturan pemerintah Nomor 10 Tahun 1961 tentang pendaftaran tanah telah diperkarakan melalui jalur pengadilan.

Berdasarkan penelitian Puslitbang pada tahun 2004 di delapan kota sampel (Kota.Bandung, Padang, Samarinda, Balikpapan, Makassar Banjarmasin, Pontianak dan Kota Manado), diperoleh data bahwa selama periode 2000 sampai awal 2004 terdapat 734 berkas sengketa tanah yang diajukan di peradilan Tata Usaha Negara (PTUN-259 perkara) maupun Peradilan Umum (PU-475 perkara). Dari jumlah tersebut hanya 123 perkara yang dicabut yaitu di PTUN 54 perkara (14\%) dan di PU 69 perkara (!3 \%). Sebanyak 611 perkara diproses lebih lanjut di pengadilan.

Demikian pula penelitian di enam kabupaten sampel pada kurun waktu yang sama (Kabupaten Bandung, .Padang Pariaman, Gowa, Banjar, Pontianak dan Kabupaten Minahasa), terdapat 324 berkas sengketa tanah yang diajukan di peradilan Tata Usaha Negara (PTUN-127 perkara) dan Peradilan Umum (PU-197 perkara). Dari jumlah tersebut hanya 35 perkara yang dicabut yaitu di PTUN-19 perkara (15\%) dan di PU 16 perkara (8\%). Sebanyak 162 perkara juga diproses lebih lanjut di pengadilan.

Jenis sengketa pertanahan yang diajukan ke peradilan TUN dan PU selama periode tersebut meliputi 13 masalah/gugatan yang sebagian besar adalah pembatalan sertipikat hak milik atas tanah. Secara lengkap jenis masalah yang diperkarakan di pengadilan adalah :

a. Pembatalan sertipikat akibat kesalahan prosedur dan sertipikat ganda (paling dominan)

b. Terbitnya sertipikat dianggap sebagai perbuatan melawan hukum 
c. Peralihan hak/balik nama yang dituntut oleh pihak yang merasa berhak

d. Sertipikat digugat oleh ahli waris yang lain

e. Pembatalan/penangguhan SK Hak

f. Pembatalan hak tanggungan karena sertipikat tanah dijaminkan untuk agunan pinjaman kredit oleh pihak yang tidak berhak.

g. Penerbitan sertipikat tanah kaum oleh pihak yang bukan menjadi anggota kaum

h. Pengukuran dan penerbitan Surat Ukur salah lokasi, tumpang tindih batas atau ukuran luas tidak benar

i. Penggugat mengakui sebagai pemilik berdasarkan kepenghunian lebih dari 20 tahun

j. $\quad$ Penolakan terbitnya Hak Baru tanah PJKA yang sudah dihuni penggugat

k. Penangguhan terbitnya Hak Baru tanah Aset Pemda

I. Kepemilikan Tanah Milik Adat

m. Penolakan ganti rugi Pembatalan SK Pengosongan tanah yang sudah dihuni penggugat

Lebih lanjut data pada Tabel 1-A (mengenai jenis sengketa pertanahan yang diperkarakan di Peradilan Umum di kabupaten sampel) dan Tabel 1-B (mengenai jenis sengketa pertanahan yang diperkarakan di Peradilan Umum di kota sampel) menunjukkan bahwa permohonan pembatalan sertipikat, termasuk penerbitan sertipikat dianggap sebagai perbuatan melawan hukum, merupakan alasan yang dominan sengketa pertanahan di pengadilan. Di kabupaten sample mencakup jumlah 63,33\%, sedangkan di kota sample mencakup jumlah $41,27 \%$ dari jumlah sengketa tanah yang diperkarakan.

Demikian pula data pada Tabel 2-A (mengenai jenis sengketa pertanahan yang diperkarakan di Peradilan TUN di kabupaten sampel) dan Tabel 2-B (mengenai jenis sengketa pertanahan yang diperkarakan di Peradilan TUN di kota sampel) juga menunjukkan hal yang sama dengan peradilan umum. Di kabupaten sample mencakup jumlah 63,64 \%, sedangkan di kota sample mencakup jumlah 82,27 \% dari jumlah sengketa tanah yang diperkarakan. (lihat Tabel 2-A dan 2-B).

Tabel 1-A.

Jumlah Sengketa Pertanahan Menurut Jenis Masalah/Gugatan yang Diajukan Ke Peradilan Umum di Kabupaten Sampel (1999 s/d Mei 2004)

\begin{tabular}{|c|c|c|c|c|c|c|c|c|c|c|c|c|c|c|c|c|c|c|c|}
\hline \multirow{2}{*}{ No } & \multirow{2}{*}{$\begin{array}{l}\text { Jenis Masalah/Gugatan } \\
\text { Yang Diajukan }\end{array}$} & \multicolumn{2}{|c|}{ Jabar } & \multicolumn{2}{|c|}{ Sumbar } & \multicolumn{2}{|c|}{ Sumut } & \multicolumn{2}{|c|}{ Sulut } & \multicolumn{2}{|c|}{ Sulsel } & \multicolumn{2}{|c|}{ Kaltim } & \multicolumn{2}{|c|}{ Kalsel } & \multicolumn{2}{|c|}{ Kalbar } & \multicolumn{2}{|c|}{ Total } \\
\hline & & $\mathrm{Jml}$ & $(\%)$ & $\mathrm{Jml}$ & $(\%)$ & Jml & $(\%)$ & $\mathrm{Jml}$ & $(\%)$ & $\mathrm{Jml}$ & $(\%)$ & $\mathrm{Jml}$ & $(\%)$ & Jml & $(\%)$ & Jml & $(\%)$ & Jml & $(\%)$ \\
\hline 1 & 2 & 3 & 4 & 5 & 6 & 7 & 8 & 9 & 10 & 11 & 12 & 13 & 14 & 15 & 16 & 17 & 18 & 13 & 14 \\
\hline 1 & Pembatalan sertipikat & 57 & 86.36 & 25 & 69.44 & $\operatorname{tad}$ & & 16 & 31.37 & 5 & 62.50 & 12 & 0.00 & 3 & 75.00 & 2 & 33.3 & 120 & 53.33 \\
\hline 2 & Peralihan hak/balik nama & 0 & 0.00 & 7 & 19.44 & & & 5 & 9.80 & 0 & 0.00 & 20 & 0.00 & 0 & 0.00 & 4 & 66.7 & 36 & 16.00 \\
\hline 3 & Masalah tanah waris & 0 & 0.00 & 0 & 0.00 & & & 8 & 15.69 & 0 & 0.00 & 12 & 0.00 & 0 & 0.00 & 0 & 0.0 & 20 & 8.89 \\
\hline 4 & $\begin{array}{l}\text { Pembatallan/Penangguhan } \\
\text { SK hak }\end{array}$ & 5 & 7.58 & 1 & 2.78 & & & 3 & 5.88 & 1 & 12.50 & 2 & 0.00 & 0 & 0.00 & 0 & 0.0 & 12 & 5.33 \\
\hline 5 & $\begin{array}{l}\text { Pembatalan hak } \\
\text { tanqqungan }\end{array}$ & 4 & 6.06 & 0 & 0.00 & & & 0 & 0.00 & 0 & 0.00 & 0 & 0.00 & 0 & 0.00 & 0 & 0.0 & 4 & 1.78 \\
\hline
\end{tabular}




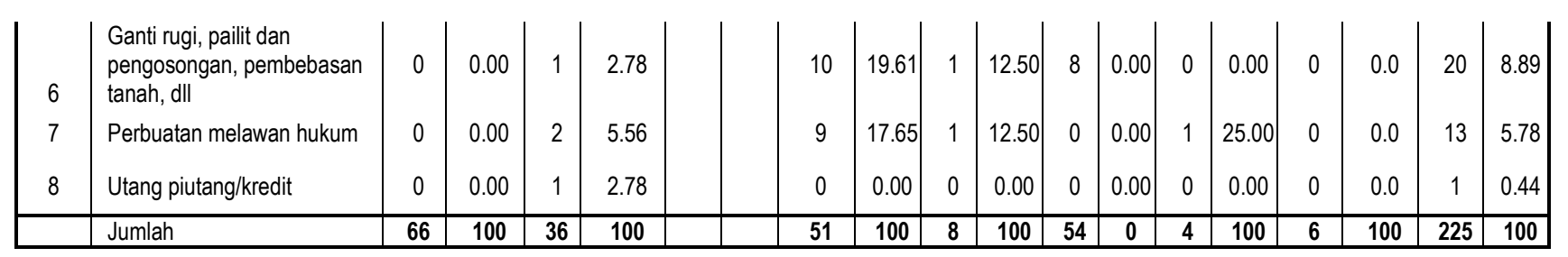

Sumber : Pengolahan data 2004.

tad $=$ Tidak ada data

Tabel 1-B.

Jumlah Sengketa Pertanahan Menurut Jenis Masalah/Gugatan yang Diajukan Ke Peradilan Umum di Kota Sampel (1999 s/d Mei 2004)

\begin{tabular}{|c|c|c|c|c|c|c|c|c|c|c|c|c|c|c|c|c|c|c|c|}
\hline \multirow{2}{*}{ No } & \multirow{2}{*}{ Jenis Masalah/Gugatan Yang Diajukan } & \multicolumn{2}{|c|}{ Jabar } & \multicolumn{2}{|c|}{ Sumbar } & \multicolumn{2}{|c|}{ Sumut } & \multicolumn{2}{|c|}{ Sulut } & \multicolumn{2}{|c|}{ Sulsel } & \multicolumn{2}{|c|}{ Kaltim } & \multicolumn{2}{|c|}{ Kalsel } & \multicolumn{2}{|c|}{ Kalbar } & \multicolumn{2}{|c|}{ Total } \\
\hline & & $\mathrm{Jml}$ & $(\%)$ & $\mathrm{Jml}$ & $(\%)$ & $\mathrm{Jml}$ & $(\%)$ & $\mathrm{Jml}$ & $(\%)$ & $\mathrm{Jml}$ & $(\%)$ & $\mathrm{Jml}$ & $(\%)$ & $\mathrm{Jml}$ & $(\%)$ & $\mathrm{Jml}$ & $(\%)$ & $\mathrm{Jml}$ & $(\%)$ \\
\hline 1 & 2 & 3 & 4 & 5 & 6 & 7 & 8 & 9 & 10 & 11 & 12 & 13 & 14 & 15 & 16 & 17 & 18 & 19 & 20 \\
\hline 1 & Pembatalan sertipikat & 41 & 28.28 & 2 & 1.15 & tad & & 5 & 27.78 & 21 & 31.34 & 36 & 64.29 & 5 & 33.33 & tad & & 110 & 23.16 \\
\hline 2 & Perbuatan melawan hukum & 25 & 17.24 & 59 & 33.91 & & & 1 & 5.56 & 0 & 0.00 & 0 & 0.00 & 1 & 6.67 & & & 86 & 18.11 \\
\hline 3 & $\begin{array}{l}\text { Gugatan lain seperti ganti rugi, pailit dan } \\
\text { pengosongan tanah }\end{array}$ & 25 & 17.24 & 0 & 0.00 & & & 4 & 22.22 & 8 & 11.94 & 8 & 14.29 & 0 & 0.00 & & & 45 & 9.47 \\
\hline 4 & Penolakan/penangguhan terbitnya Hak Baru & 0 & 0.00 & 0 & 0.00 & & & 0 & 0.00 & 15 & 22.39 & 5 & 8.93 & 0 & 0.00 & & & 20 & 4.21 \\
\hline 5 & Pembatalan peralihan hak & 8 & 5.52 & 24 & 13.79 & & & 4 & 22.22 & 0 & 0.00 & 3 & 5.36 & 8 & 53.33 & & & 47 & 9.89 \\
\hline 6 & Utang piutang/kredit & 28 & 19.31 & 0 & 0.00 & & & 1 & 5.56 & 0 & 0.00 & 0 & 0.00 & 0 & 0.00 & & & 29 & 6.11 \\
\hline 7 & Tidak diketahui jenis masalahnya & 0 & 0.00 & 28 & 16.09 & & & 0 & 0.00 & 0 & 0.00 & 0 & 0.00 & 0 & 0.00 & & & 28 & 5.89 \\
\hline 8 & Tanah waris & 0 & 0.00 & 18 & 10.34 & & & 0 & 0.00 & 9 & 13.43 & 0 & 0.00 & 0 & 0.00 & & & 27 & 5.68 \\
\hline 9 & $\begin{array}{l}\text { Penerbitan sertipikat tanah kaum oleh bukan } \\
\text { anggota kaum }\end{array}$ & 0 & 0.00 & 27 & 15.52 & & & 0 & 0.00 & 0 & 0.00 & 0 & 0.00 & 0 & 0.00 & & & 27 & 5.68 \\
\hline 10 & Bantahan eksekusi & 14 & 9.66 & 0 & 0.00 & & & 1 & 5.56 & 0 & 0.00 & 0 & 0.00 & 0 & 0.00 & & & 15 & 3.16 \\
\hline 11 & Pencaplokan bidang tanah & 0 & 0.00 & 0 & 0.00 & & & 0 & 0.00 & 14 & 20.90 & 0 & 0.00 & 0 & 0.00 & & & 14 & 2.95 \\
\hline 12 & Pengukuran dan penerbitan Surat Ukur & & 0.00 & 9 & 5.17 & & & 0 & 0.00 & 0 & \begin{tabular}{|l|}
0.00 \\
\end{tabular} & 0 & 0.00 & 0 & 0.00 & & & 9 & 1.89 \\
\hline 13 & Penolakan putusan PTUN & 0 & 0.00 & 0 & 0.00 & & & 0 & 0.00 & 0 & 0.00 & 4 & 7.14 & 0 & 0.00 & & & 4 & 0.84 \\
\hline 14 & Pembatalan hak tanggungan & 4 & 2.76 & 0 & 0.00 & & & 2 & 11.11 & 0 & 0.00 & 0 & 0.00 & 0 & 0.00 & & & 6 & 1.26 \\
\hline 15 & Pemecahan & 0 & 0.00 & 6 & 3.45 & & & 0 & 0.00 & 0 & 0.00 & 0 & 0.00 & 0 & 0.00 & & & 6 & 1.26 \\
\hline 16 & Yang berkaitan dengan Pemda & 0 & 0.00 & 1 & 0.57 & & & 0 & 0.00 & 0 & 0.00 & 0 & 0.00 & 0 & 0.00 & & & 1 & 0.21 \\
\hline 17 & Lelang agunan & 0 & 0.00 & 0 & 0.00 & 0 & & 0 & 0.00 & 0 & 0.00 & 0 & 0.00 & 1 & 6.67 & & & 1 & 0.21 \\
\hline & Jumlah & 145 & 100 & 174 & 100 & 0 & - & 18 & 100 & 67 & 100 & 56 & 100 & 15 & 100 & 0 & 0 & 475 & 100 \\
\hline
\end{tabular}

Sumber : Pengolahan data 2004

tad $=$ Tidak ada data

Tabel 2-A

Jumlah Sengketa Pertanahan Menurut Jenis Masalah/Gugatan yang Diajukan Ke Peradilan Tata Usaha Negara di Kabupaten Sampel (1999 s/d Mei 2004)

\begin{tabular}{|c|c|c|c|c|c|c|c|c|c|c|c|c|c|c|c|c|c|c|c|}
\hline \multirow{2}{*}{$\begin{array}{l}N \\
0\end{array}$} & \multirow{2}{*}{$\begin{array}{c}\text { Jenis } \\
\text { Masalah/Gugat } \\
\text { an Yang } \\
\text { Diajukan }\end{array}$} & \multicolumn{2}{|c|}{ Jabar } & \multicolumn{2}{|c|}{ Sumbar } & \multicolumn{2}{|c|}{ Sumut } & \multicolumn{2}{|c|}{ Sulut } & \multicolumn{2}{|c|}{ Sulsel } & \multicolumn{2}{|c|}{ Kaltim } & \multicolumn{2}{|c|}{ Kalsel } & \multicolumn{2}{|c|}{ Kalbar } & \multicolumn{2}{|c|}{ Total } \\
\hline & & $\mathrm{Jml}$ & $(\%)$ & $\mathrm{Jml}$ & $(\%)$ & $\mathrm{Jml}$ & $(\%)$ & $\mathrm{Jml}$ & $(\%)$ & $\mathrm{Jml}$ & $(\%)$ & $\mathrm{Jml}$ & $(\%)$ & Jml & $(\%)$ & $\mathrm{Jml}$ & $(\%)$ & $\mathrm{Jml}$ & $(\%)$ \\
\hline 1 & 2 & 3 & 4 & 5 & 6 & 7 & 8 & 9 & 10 & 11 & 12 & 13 & 14 & 15 & 16 & 17 & 18 & 19 & 20 \\
\hline
\end{tabular}




\begin{tabular}{|c|c|c|c|c|c|c|c|c|c|c|c|c|c|c|c|c|c|}
\hline 1 & $\begin{array}{l}\text { Pembatalan } \\
\text { sertipikat }\end{array}$ & 19 & 65.52 & 0 & - & 4 & 36.36 & 15 & 88.24 & 10 & 83.33 & 1 & 100 & 19 & 52.78 & 68 & 61.82 \\
\hline 2 & $\begin{array}{l}\text { Pemblokiran } \\
\text { peralihan }\end{array}$ & 7 & 24.14 & 0 & - & 3 & 27.27 & 1 & 5.88 & 2 & 16.67 & 0 & - & 0 & - & 13 & 11.82 \\
\hline 3 & $\begin{array}{l}\text { Tumpang tindih } \\
\text { sertifikat }\end{array}$ & 3 & 10.34 & 0 & - & 0 & - & 0 & - & 0 & - & 0 & - & 12 & 33.33 & 15 & 13.64 \\
\hline 4 & $\begin{array}{l}\text { Kesalahan } \\
\text { prosedur }\end{array}$ & 0 & - & 2 & 50 & 0 & - & 1 & 5.88 & 0 & - & 0 & - & 0 & - & 3 & 2.73 \\
\hline 5 & $\begin{array}{l}\text { Perbuatan } \\
\text { melawan hukum }\end{array}$ & 0 & - & 2 & 50.00 & 0 & - & 0 & - & 0 & - & 0 & - & 0 & - & 2 & 1.82 \\
\hline 6 & $\begin{array}{l}\text { Pemilikan } \\
\text { TMA/Waris }\end{array}$ & 0 & - & 0 & - & 2 & 18.18 & 0 & - & 0 & - & 0 & - & 5 & 13.89 & 7 & 6.36 \\
\hline 7 & $\begin{array}{l}\text { Tolak proses } \\
\text { pemberian SK } \\
\text { HAT }\end{array}$ & 0 & - & 0 & - & 2 & 18.18 & 0 & - & 0 & - & 0 & - & 0 & - & 2 & 1.82 \\
\hline & Jumlah & 29 & 100.0 & 4 & 100.0 & 11 & 100.0 & 17 & 100.0 & 12 & 100.0 & 1 & 100.0 & 36 & 100.0 & 110 & 100.0 \\
\hline
\end{tabular}

Tabel 2-B

Jumlah Sengketa Pertanahan Menurut Jenis Masalah/Gugatan yang Diajukan Ke Peradilan Tata Usaha Negara di Kota Sampel (1999 s/d Mei 2004)

\begin{tabular}{|c|c|c|c|c|c|c|c|c|c|c|c|c|c|c|c|c|c|c|c|}
\hline \multirow{2}{*}{ No } & \multirow{2}{*}{$\begin{array}{c}\text { Jenis } \\
\text { Masalah/Gugat } \\
\text { an Yang } \\
\text { Diajukan }\end{array}$} & \multicolumn{2}{|c|}{ Jabar } & \multicolumn{2}{|c|}{ Sumbar } & \multicolumn{2}{|c|}{ Sumut } & \multicolumn{2}{|c|}{ Sulut } & \multicolumn{2}{|c|}{ Sulsel } & \multicolumn{2}{|c|}{ Kaltim } & \multicolumn{2}{|c|}{ Kalsel } & \multicolumn{2}{|c|}{ Kalbar } & \multicolumn{2}{|c|}{ Total } \\
\hline & & $\mathrm{Jml}$ & $(\%)$ & $\mathrm{Jml}$ & $(\%)$ & $\mathrm{Jml}$ & (\%) & $\mathrm{Jml}$ & $(\%)$ & $\mathrm{Jml}$ & $(\%)$ & $\mathrm{Jml}$ & $(\%)$ & $\mathrm{Jml}$ & $(\%)$ & $\mathrm{Jml}$ & $(\%)$ & $\mathrm{Jml}$ & $(\%)$ \\
\hline 1 & 2 & 3 & 4 & 11 & 12 & 11 & 12 & 5 & 6 & 7 & 8 & 9 & 10 & 9 & 10 & 9 & 10 & 13 & 14 \\
\hline 1 & $\begin{array}{l}\text { Pembatalan } \\
\text { sertipikat }\end{array}$ & 90 & 90.91 & 2 & 33.33 & & & 16 & 39.02 & 64 & 56.64 & 9 & 64.29 & 2 & 100.00 & 33 & 100.00 & 172 & 66.41 \\
\hline 2 & $\begin{array}{l}\text { Kesalahan } \\
\text { prosedur }\end{array}$ & 0 & 0.00 & 0 & 0.00 & & & 7 & 17.07 & 34 & 30.09 & 0 & 0.00 & 0 & 0.00 & 0 & 0.00 & 41 & 15.83 \\
\hline 3 & $\begin{array}{l}\text { Pembatalan } \\
\text { Proses SK HAT }\end{array}$ & 5 & 5.05 & 2 & 33.33 & & & 18 & 43.90 & 0 & 0.00 & 5 & 35.71 & 0 & 0.00 & 0 & 0.00 & 25 & 9.65 \\
\hline 4 & $\begin{array}{l}\text { Gugatan } \\
\text { sertipikat ganda }\end{array}$ & 0 & 0.00 & 0 & 0.00 & & & 0 & 0.00 & 15 & 13.27 & 0 & 0.00 & 0 & 0.00 & 0 & 0.00 & 15 & 5.79 \\
\hline 5 & $\begin{array}{l}\text { Perlawanan } \\
\text { putusan PTUN }\end{array}$ & 3 & 3.03 & 0 & 0.00 & & & 0 & 0.00 & 0 & 0.00 & 0 & 0.00 & 0 & 0.00 & 0 & 0.00 & 3 & 1.16 \\
\hline 6 & Pemilikan TMA & 1 & 1.01 & 2 & 33.33 & & & 0 & 0.00 & 0 & 0.00 & 0 & 0.00 & 0 & 0.00 & 0 & 0.00 & 3 & 1.16 \\
\hline 7 & $\begin{array}{l}\text { Sengketa } \\
\text { lainnya } \\
\text { termasuk } \\
\text { pemecahan }\end{array}$ & 0 & 0.00 & 6 & 100.00 & & & 0 & 0.00 & 6 & 5.31 & 0 & 0.00 & 0 & 0.00 & 7 & 21.21 & 12 & 4.63 \\
\hline & Jumlah & 99 & 100.00 & 6 & 100.00 & & & 41 & 100.00 & 113 & 100.00 & 14 & 100.00 & 2 & 100.00 & 33 & 100.00 & 259 & 100.00 \\
\hline
\end{tabular}

\section{B. Posisi Kantor Pertanahan di Pengadilan}

\section{Sengketa Pertanahan Yang Diajukan ke Pengadilan}

Badan Pertanahan Nasional sebagai instansi pemerintah yang melaksanakan urusan pertanahan seringkali mengalami masalah dan kendala dalam pelaksanaan tugas, pokok dan fungsinya. Masalah ini terjadi karena adanya ke tidak puasan dari masyarakat terhadap produk dari BPN yaitu sertifikat. 
Hasil penelitian menunjukkan bahwa dari 108 perkara yang diajukan ke Pengadilan di kabupaten sampel, posisi BPN/Kantor Pertanahan pada saat ini lebih banyak yang dinyatakan menang oleh hakim. Di Pengadilan Tingkat Pertama, dari 54 perkara yang telah diputus hakim 31 perkara $(24 \%)$ Kantor Pertanahan dinyatakan menang, 23 perkara (18\%) dinyatakan kalah dan 54 perkara lainnya masih dalam proses pemeriksaan. Kemudian pada tingkat banding, dari 37 perkara yang diputus oleh majelis hakim, 24 perkara (19 \%) Kantor Pertanahan dinyatakan menang, 13 perkara (10\%) dinyatakan kalah. Selanjutnya di tingkat kasasi terdapat tujuh amar putusan hakim,, sebanyak tujuh putusan hakim (6\%) BPN/Kantor Pertanahan dinyatakan menang dan sebanyak 4 putusan hakim $(3 \%)$ dinyatakan kalah. Selama periode 5 tahun hanya terdapat 16 perkara yang mendapat putusan tetap (inkracht). (lihat tabel 3.A)

\section{Sengketa Pertanahan Yang Diajukan Ke Peradilan Umum}

Penelitian di enam kabupaten sampel, selama periode 1999 sampai 2004, terdapat 181 perkara yang diajukan ke peradilan umum. Di Pengadilan tingkat pertama, dari 141 perkara yang telah diputus hakim, 82 perkara (42\%), Kantor Pertanahan dinyatakan menang, 59 perkara (30 \%) dinyatakan kalah dan 40 perkara lainnya masih dalam proses pemeriksaan. Selanjutnya di tingkat banding, dari 75 perkara yang diputus oleh majelis, 52 perkara (26\%) Kantor Pertanahan dinyatakan menang, 23 perkara (12\%) dinyatakan kalah. Sedangkan di tingkat kasasi terdapat 16 putusan hakim, yang mana sebanyak 11 putusan (6\%) BPN/Kantor Pertanahan dinyatakan menang dan sebanyak 5 putusan (3\%) dinyatakan kalah. Selama periode 5 tahun terdapat 21 perkara yang mendapat putusan hakim yang bersifat tetap (inkracht).

Hasil penelitian di delapan daerah kota sampel, selama periode 1999 sampai dengan tahun 2004, terdapat 471 perkara yang diajukan ke peradilan umum. Di Pengadilan Tingkat Pertama, dari sebanyak 287 perkara yang telah diputus olah hakim, terdapat 189 perkara $(35 \%)$ Kantor Pertanahan dinyatakan menang, 96 perkara $(18 \%)$ dinyatakan kalah. Sebanyak 40 perkara lainnya masih dalam proses pemeriksaan. Selanjutnya di pengadilan tingkat banding, dari 183 perkara yang diputus oleh majelis, terdapat 136 perkara (26 \%) Kantor Pertanahan dinyatakan menang, 47 perkara (9\%) dinyatakan kalah. Sedangkan di tingkat Kasasi terdapat 10 putusan hakim, yang mana sebanyak 6 putusan BPN/Kantor Pertanahan dinyatakan menang dan sebanyak 4 putusan dinyatakan kalah. Selama periode 5 tahun terdapat 10 perkara yang mendapat putusan hakim yang bersifat tetap (inkracht).(lihat tabel 3.B)

Tabel 3-A

Jumlah Sengketa Pertanahan Yang Diselesaikan Melalui Peradilan Tata Usaha Negara (TUN) Tahun 1999 s/d 2004 (Mei).

\begin{tabular}{|c|c|c|c|c|c|c|c|c|c|c|c|c|c|c|c|}
\hline \multirow{2}{*}{ No } & \multirow{2}{*}{ Provinsi } & \multicolumn{3}{|c|}{ Perkara yang diajukan } & \multicolumn{2}{|c|}{ Peradilan Tk.I } & \multicolumn{2}{|c|}{$\begin{array}{c}\text { Peradilan } \\
\text { Banding }\end{array}$} & \multicolumn{2}{|c|}{$\begin{array}{c}\text { Peradilan } \\
\text { Kasasi }\end{array}$} & \multicolumn{5}{|c|}{ Proses Penyelesaian } \\
\hline & & $\begin{array}{l}\text { Juml } \\
\text { ah }\end{array}$ & Cabut & Maju & $\begin{array}{l}\text { Men } \\
\text { ang }\end{array}$ & $\begin{array}{c}\text { Kala } \\
\mathrm{h}\end{array}$ & $\begin{array}{l}\text { Men } \\
\text { ang }\end{array}$ & $\begin{array}{c}\text { Kala } \\
\mathrm{h}\end{array}$ & $\begin{array}{l}\text { Men } \\
\text { ang }\end{array}$ & $\begin{array}{c}\text { Kala } \\
\mathrm{h}\end{array}$ & $\begin{array}{c}\text { Incra } \\
\text { cht }\end{array}$ & $\begin{array}{c}\text { Kasa } \\
\text { si }\end{array}$ & $\begin{array}{l}\text { Ban } \\
\text { ding }\end{array}$ & $\begin{array}{r}\text { PN } \\
\text { Tk.I }\end{array}$ & Damai \\
\hline 1 & 2 & 3 & 4 & 5 & 6 & 7 & 8 & 9 & 10 & 11 & 12 & 13 & 14 & 15 & 16 \\
\hline & $\begin{array}{l}\text { Sampel } \\
\text { Kabupaten }\end{array}$ & & & & & & & & & & & & & & \\
\hline 1 & Jawa Barat & 34 & 5 & 29 & 12 & 10 & 7 & 6 & 3 & 2 & 6 & 6 & ** & ** & 1 \\
\hline $\begin{array}{l}2 \\
3\end{array}$ & $\begin{array}{l}\text { Sumatera Barat } \\
\text { Sumatera Utara }\end{array}$ & 4 & 0 & 4 & 1 & 3 & 1 & 1 & 0 & 0 & 0 & 2 & 0 & 2 & 0 \\
\hline
\end{tabular}




\begin{tabular}{|c|c|c|c|c|c|c|c|c|c|c|c|c|c|c|c|}
\hline 4 & Sulawesi Utara & 12 & 1 & 11 & 8 & 2 & 8 & 2 & 3 & 1 & $* *$ & ** & ** & $* *$ & ** \\
\hline 5 & Sulawesi Selatan & 20 & 3 & 17 & 7 & 4 & 6 & 2 & 1 & 0 & 8 & 6 & 4 & 1 & 1 \\
\hline 6 & $\begin{array}{l}\text { Kalimantan Timur } \\
\text { Kalimantan }\end{array}$ & 12 & 2 & 10 & 3 & 4 & 2 & 2 & 0 & 1 & 2 & 3 & 0 & 2 & 0 \\
\hline 7 & Selatan & 1 & & 1 & ** & $* \star$ & $* *$ & ** & ** & ** & $* *$ & $* *$ & ** & $* *$ & ** \\
\hline 8 & Kalimantan Barat & 44 & 8 & 36 & ** & ** & ** & ** & ** & ** & ** & ** & ** & ** & ** \\
\hline & Jumlah & 127 & 19 & 108 & 31 & 23 & 24 & 13 & 7 & 4 & 16 & 17 & 4 & 5 & 2 \\
\hline & Persentase(\%) & 100.00 & 14.96 & 85.04 & 24.41 & 18.11 & 18.90 & 10.24 & 5.51 & 3.15 & 12.60 & 13.39 & 3.15 & 3.94 & 1.57 \\
\hline & \multicolumn{15}{|l|}{ Sampel Kota } \\
\hline 1 & Jawa Barat & 110 & 11 & 99 & 59 & 32 & 33 & 7 & 0 & 1 & 2 & $* *$ & 0 & 7 & 1 \\
\hline 2 & Sumatera Barat & 13 & 1 & 12 & 5 & 5 & 5 & 1 & 0 & 0 & 3 & 1 & 0 & 2 & 2 \\
\hline 3 & Sumatera Utara & & & & & & & & & & & & & & \\
\hline 4 & Sulawesi Utara & 41 & 0 & 41 & 17 & 24 & 26 & 15 & 35 & 6 & $* *$ & ${ }^{* *}$ & ** & $* *$ & ** \\
\hline 5 & Sulawesi Selatan & 154 & 35 & 119 & ** & $* *$ & ** & ** & ** & ** & $* *$ & ** & ** & $* *$ & ** \\
\hline 6 & $\begin{array}{l}\text { Kalimantan Timur } \\
\text { Kalimantan }\end{array}$ & 14 & 2 & 12 & 6 & 2 & 5 & 3 & 2 & 0 & 2 & 2 & 1 & 4 & 0 \\
\hline 7 & Selatan & 2 & 0 & 2 & & 2 & & 1 & & & & & & & \\
\hline \multirow[t]{5}{*}{8} & Kalimantan Barat & 45 & 5 & 40 & 16 & 20 & 8 & 1 & & & & & 22 & & \\
\hline & \multirow{2}{*}{$\begin{array}{l}\text { Jumlah } \\
\text { Persentase (\%) }\end{array}$} & 379 & 54 & 325 & 103 & 85 & 77 & 28 & 37 & 7 & 7 & 3 & 23 & 13 & 3 \\
\hline & & 100.00 & 14.25 & 85.75 & 27.18 & 22.43 & 20.32 & 7.39 & 9.76 & 1.85 & 1.85 & 0.79 & 6.07 & 3.43 & 0.79 \\
\hline & Total Jumlah & 506 & 73 & 433 & 134 & 108 & 101 & 41 & 44 & 11 & 23 & 20 & 27 & 18 & 5 \\
\hline & Persentase (\%) & 100.00 & 14.43 & 85.57 & 26.48 & 21.34 & 19.96 & 8.10 & 8.70 & 2.17 & 4.55 & 3.95 & 5.34 & 3.56 & 0.99 \\
\hline
\end{tabular}

Sumber : Pengolahan data 2004.

Keterangan : ** Tidak ada data

Tabel 3-B

Jumlah Sengketa Pertanahan Yang Diselesaikan Melalui Peradilaan Umum Tahun 1999 s/d 2004 (Mei).

\begin{tabular}{|c|c|c|c|c|c|c|c|c|c|c|c|c|c|c|c|}
\hline \multirow{2}{*}{$\begin{array}{l}\mathrm{N} \\
0\end{array}$} & \multirow[b]{2}{*}{ Provinsi } & \multicolumn{3}{|c|}{ Perkara yang diajukan } & \multicolumn{2}{|c|}{ Peradilan Tk.I } & \multicolumn{2}{|c|}{ Peradilan Banding } & \multicolumn{2}{|c|}{ Peradilan Kasasi } & \multicolumn{5}{|c|}{ Proses Penyelesaian } \\
\hline & & jlh & $\begin{array}{l}\mathrm{Ca} \\
\text { but }\end{array}$ & Maju & Mng & Kalah & Mng & Kalah & Mng & Kalah & $\begin{array}{c}\text { Inkra } \\
\text { cht }\end{array}$ & $\begin{array}{r}\mathrm{Ka} \\
\text { sasi }\end{array}$ & $\begin{array}{c}\text { Bandi } \\
\mathrm{ng}\end{array}$ & $\begin{array}{r}\text { PN } \\
\text { Tk.I }\end{array}$ & $\begin{array}{c}\mathrm{Da} \\
\text { mai }\end{array}$ \\
\hline \multirow[t]{2}{*}{1} & 2 & 3 & 4 & 5 & 6 & 7 & 8 & 9 & 10 & 11 & 12 & 13 & 14 & 15 & 16 \\
\hline & \multicolumn{15}{|c|}{ Sampel Kabupaten } \\
\hline 1 & Jawa Barat & 76 & 10 & 66 & 25 & 27 & 11 & 11 & 3 & 3 & 11 & 0 & 0 & 17 & 0 \\
\hline 2 & Sumatera Barat & 40 & 4 & 36 & 14 & 10 & 6 & 2 & 0 & 0 & 1 & 8 & 12 & 1 & 0 \\
\hline 3 & Sumatera Utara & & & 0 & & & & & & & & & & & \\
\hline 4 & Sulawesi Utara & 51 & 0 & 51 & 31 & 12 & 26 & 7 & 7 & 2 & ** & $* *$ & ** & $* *$ & $* *$ \\
\hline 5 & Sulawesi Selatan & 8 & 0 & 8 & 7 & 4 & 6 & 2 & 1 & 0 & 8 & 6 & 4 & 1 & 1 \\
\hline 6 & Kalimantan Timur & 12 & 2 & 10 & 5 & 2 & 3 & 1 & 0 & 0 & 1 & 1 & 1 & 3 & 3 \\
\hline 7 & $\begin{array}{l}\text { Kallmantan } \\
\text { Selatan }\end{array}$ & 4 & & 4 & & 4 & & & & & & & 4 & & \\
\hline
\end{tabular}




\begin{tabular}{|c|c|c|c|c|c|c|c|c|c|c|c|c|c|c|c|}
\hline 8 & Kalimantan Barat & 6 & & 6 & & & & & & & & & & & \\
\hline & Jumlah & 197 & 16 & 181 & 82 & 59 & 52 & 23 & 11 & 5 & 21 & 15 & 21 & 22 & 4 \\
\hline & Persentase (\%) & 100.00 & 8.12 & 91.88 & 41.62 & 29.95 & 26.40 & 11.68 & 5.58 & 2.54 & 10.66 & 7.61 & 10.66 & 11.17 & 2.03 \\
\hline
\end{tabular}

\section{Analisis Kompetensi Peradilan Mengenai Sengketa Pertanahan}

Kasus kasus peradilan pertanahan di berbagai kota dan kabupaten jika diamati menggambarkan ketidakpastian kompetensi struktur lembaga peradilan dalam menangani sengketa pertanahan yang meliputi pihak-pihak yang bersengketa, dengan atau tanpa bantuan Pengacara, Kantor Pertanahan, Penyidik (Kepolisian dan Kejaksaan) serta Lembaga Peradilan TUN maupun Peradilan Umum.

Produk sertipikat hak atas tanah yang merupakan produk administrasi pelayanan publik, manakala terjadi sengketa, jika tidak melalui jalur musyawarah, maka salah satu pihak dapat membawa kasusnya ke Peradilan TUN. Namun peradilan TUN hanya bisa memutuskan perkara yang berkaitan dengan soal administrasi ketatausahaan negara. Peradilan TUN tidak berwenang memutuskan perkara yang termasuk dalam lingkup hukum perdata hak atas tanah sehingga problematik yang dihadapi masyarakat sehubungan dengan sengketa pertanahan adalah : apakah pemeriksaan atas perkara tersebut menjadi kompetensi Peradilan TUN atau kompetensi Peradilan Umum ? (Sarodjo 2002).

Karena sengketa pertanahan tersebut juga dapat dianggap sebagai kasus gugataan perdata, yang menambah rumitnya peradilan sengketa pertanahan. Kasus yang diajukan ke Peradilan TUN, Tingkat Pertama, jika salah satu pihak tidak menerima putusan tersebut dapat melakukan Banding ke Pengadilan Tingkat Tinggi. Jika tidak menerima hasil putusan Peradilan Banding dapat diajukan Kasasi ke Mahkamah Agung. Ternyata hasil putusan MA juga tidak langsung dapat dilaksanakan, karena ada mekanisme Peninjauan Kembali (PK). Beberapa putusan MA meskipun tidak dilakukan PK juga ternyata ada yang sulit dilaksanakan di lapangan karena masyarakat menolak putusan tersebut (Kasus Perkebunan di Sulawesi Selatan) .

Selanjutnya pihak yang merasa dirugikan dapat pula mengajukan jalur melalui Peradilan Umum, dengan delik perdata pertanahan. Maka berlangsunglah proses peradilan perdata pertanahan mulai dari Peradilan Umum Tingkat Pertama, Tingkat Banding, Kasasi dan PK.

Untuk satu perkara sengketa pertanahan yang dimulai dari penyidik Kepolisian atau Kejaksaan dan diproses di Peradilan TUN maupun Peradilan Umum, memakan waktu bertahun-tahun, sehingga sebagian waktu, tenaga dan sumberdaya lain yang dimiliki Kantor Pertanahan terserap untuk memberi keterangan, dan menjelaskan, baik sebagai Saksi atau Tergugat. Selaku tergugat, sebagian besar BPN/Kantor Pertanahan sebagai pihak Tergugat Tunggal atau Tergugat I sampai Tergugat III. Namun di Kota Bandung ditemukan pula BPN/Kantor Pertanahan sebagai Tergugat XXX sampai Tergugat XXXVIII.

Hasil penelitian juga mengindikasikan bahwa Kantor Pertanahan yang produk sertipikatnya tinggi, cenderung berpotensi untuk menghasilkan gugatan sengketa yang tinggi pula. Maka bagi aparat pertanahan berlakulah situasi : "Tiada hari tanpa sengketa tanah di peradilan ". Dalam hal ini apakah 
produk administrasi tersebut memang tidak dapat dilindungi dari potensi gugatan ? atau dengan kata lain bagaimana pihak Kantor Pertanahan sendiri melakukan peningkatan standar operasional prosedur yang dapat melindungi produk maupun aparatnya dari lingkaran kompetensi peradilan sengketa pertanahan ?

\section{Bentuk Keputusan Hakim}

\section{Komparasi Bentuk Putusan Peradilan}

\section{Tabel 4 : Komparasi Bentuk-bentuk Putusan Peradilan}

\begin{tabular}{|l|l|}
\hline Nomor Urut & $\mathbf{1}$ \\
\hline $\begin{array}{l}\text { Lokasi } \\
\text { Kasus }\end{array}$ & Kota Bandung, Jawa Barat \\
\hline $\begin{array}{l}\text { Pihak yang } \\
\text { berseng } \\
\text { keta }\end{array}$ & $\begin{array}{l}\text { 1. Penggugat : Ny. Clara Sitompul } \\
\text { 2. Tergugat I : Kakantah Kota Bandung } \\
\text { 3. Tergugat II : Raden Soeryo Wirjohadiputro }\end{array}$ \\
\hline $\begin{array}{l}\text { Jenis } \\
\text { Sengketa }\end{array}$ & Sengketa Kepemilikan \\
\hline Duduk Perkara &
\end{tabular}

1. bahwa yang dipermasalahkan dalam perkara ini yaitu sertipikat Hak Milik No. 341/Lebak Gede SU Nomor 336/1918 tanggal 5 April 1965 luas 2263 m² $^{2}$ tertulis a.n. Raden Soeryo Wiryohadiputro, tertanggal 13 Oktober 1990

2. bahwa Surat Hak Milik Nomor 341/Lebak Gede adalah merupakan perubahan dari Sertipikat

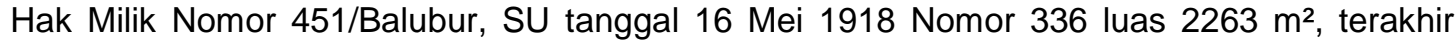
tertulis a.n. Raden Soeryo Wiryohadiputro, karena adanya pemecahan/pemekaran wilayah (semula masuk Kelurahan Balubur, sekarang menjadi Kelurahan Lebak Gede)

3. bahwa menurut penggugat, penerbitan Sertipikat Hak Milik Nomor 341/Lebak Gede tahun 1990 adalah tidak sah karena terhadap tanah yang sama, tanggal 14 Juli 1966 telah diterbitkan Sertipikat Hak Milik Nomor 451/Balubur tahun 1966 a.n. Haji Kito Nasution yang pada tahun 1974 sudah dibalik nama menjadi a.n. Raden Soeryo (Tergugat 2)

4. bahwa dengan demikian pada saat ini terhadap tanah yang sama terdapat dua Sertipikat Hak Milik yaitu Sertipikat Hak Milik Nomor 451/Balubur tahun 1966 dan Nomor 341/Lebakgede tahun 1990. Kedua-duanya tertulis atas nama Raden Soeryo (versi penggugat)

5. bahwa penggugat mengklaim tanah obyek sengketa adalah miliknya berdasarkan terbitnya Surat ljin Menghuni (SIM) yang terbit pada tanggal 9 Mei 1964 Nomor 98/64 kepada a.n. Bonar Sitompul (suami penggugat) yang diterbitkan oleh Kantor Urusan Perumahan Kotamadya Bandung

6. bahwa Tergugat II mengklaim tanah obyek sengketa berdasarkan kepemilikkan atas SHM Nomor 341/Lebakgede

7. bahwa pada kolom asal persil tidak tercantum mutasi-mutasi, padahal sertipikat asal HGB Nomor 417/Balubur telah beberapa kali terjadi perubahan pemilik.

\begin{tabular}{|l|}
\hline A. Putusan Peradilan Tata Usaha Negara \\
\hline Tingkat Pertama \\
\hline Pertimbangan Hukum \\
\hline 1. menimbang bahwa perubahan/pergantian SHM No. 451/Balubur menjadi SHM No. 341/Lebak \\
\hline
\end{tabular}


Gede adalah berdasarkan SK Gubernur Kepala Daerah Tingkat I Jawa Barat Nomor 414.13/SK 1815 Pemdes 81 tertanggal 10 September 1981 tentang pemekaran kelurahan

2. menimbang bahwa dalam PP Nomor 10/1961, tidak ada diatur tentang perubahan.penggantian sertipikat berdasarkan atas dasar pemekaran kelurahan

3. menimbang bahwa mengenai perubahan/penggantian sertipikat dalam PP Nomor 10/1961 mengatur tentang perubahan/penggantian sertipikat yang rusak dan hilang (Pasal 33)

4. menimbang bahwa perubahan/penggantian surat tersebut dilakukan oleh Tergugat I tidak didasarkan hukum pada perundang-undangan yang berlaku dalam hal ini PP Nomor 10/1961 tentang Pendaftaran Tanah

5. menimbang bahwa berdasarkan alasan-alasan tersebut diatas, majelis berpendapat bahwa perubahan/penggantian sertipikat Hak Milik Nomor 451/Balubur menjadi Sertipikat Hak Milik Nomor 341/Lebakgede tanggal 13 Oktober 1990 yang dilakukan Tergugat I bertentangan dengan peraturan perundangan yang berlaku, maka alasan-alasan lainnya yang mengakibatkan timbulnya perbuatan hukum Tergugat I ( T1) tersebut tidak perlu dipertimbangkan lagi

6. menimbang bahwa berdasarkan alasan-alasan tersebut diatas majelis berpendapat bahwa Surat Hak Milik Nomor 341 Lebak Gede tanggal 13 Oktober 1990 atas nama Raden Soeryo harus dibatalkan

7. menimbang bahwa masalah sengketa kepemilikan, peradilan Tata Usaha Negara tidak berwenang untuk memeriksa dan mengadilinya melainkan kewenangan peradilan umum,maka dalil-dalil Tergugat 2 tidak perlu dipertimbangkan.

\section{Putusan}

1. mengabulkan gugatan penggugat

2. menyatakan batal Sertipikat Hak Milik Nomor 341/Lebak Gede, SU (Surat Ukur) tanggal 5 April 1965 Nomor 336/1998 luas 2263 m², a.n. Raden Soeryo Wirjohadiputro

\section{Tingkat Banding}

Pertimbangan Hukum

1. bahwa permohonan banding dari Tergugat/pembanding masih dalam waktu dan menurut cara yang ditentukan oleh Undang-Undang

2. bahwa memori banding $(\mathrm{mb})$ yang diajukan oleh Tergugat/pembanding tidak ada fakta-fakta yang dapat membatalkan putusan-putusan PTUN Bandung

3. bahwa setelah dipelajari dengan seksama dan dihubungkan dengan bukti-bukti, maka majelis hakim Pengadilan Tinggi TUN berpendapat bahwa alasan-alasan dan pertimbangan hukum dalam putusan PTUN Bandung tanggal 9 Desember 1993 sudah tepat dan benar, sehingga seluruh pertimbangannya baik pertimbangan dan eksepsi maupun dalam pokok perkara diambil alih oleh majelis hakim PTUN menjadi pertimbangan sendiri, namun ada penambahan pertimbangan yaitu:

bahwa menurut PP Nomor 223 Tahun 1961 tentang Pedoman Pelaksanaan Pasal 4 dan

Pasal 5 Undang-Undang Nomor 3 PRP Tahun 1960 tentang penguasaan benda-benda tetap milik perseorangan warga negara Belanda, bahwa dalam bab I tersebut:

* di dalam penentuan perurutan pengutamaan maka yang dijadikan kriteria adalah: 


\begin{tabular}{|c|c|}
\hline \multicolumn{2}{|c|}{$\begin{array}{l}\text { a). status pemohon sebagai pegawai negeri } \\
\text { b). penghuni } \\
\text { c). belum punya rumah/tanah sendiri } \\
\text { - } \quad \text { bahwa para penggugat adalah para penghuni dari rumah sengketa (berdasar SIM) maka } \\
\text { terpenuhi kriteria b } \\
\text { - } \text { untuk kriteria c, penggugat/terbanding belum punya rumah sendiri jadi harus diberi hak } \\
\text { prioritas } \\
\text { menimbang bahwa Arend Van Leeuwen telah memberi kuasa kepada suami dari } \\
\text { penggugat untuk menjual dan menagih sewa tanah tersebut, dan sementara suami } \\
\text { penggugat sedang mengurus proses pembelian rumah tersebut, ternyata telah terjadi jual } \\
\text { beli antara Arend Van Leeuwen sebagai penjual kepada CV Wangijaya Trading Co (yang } \\
\text { kemudian dijual lagi kepada Raden Soeryo), yang mana menurutketentuan hukum dan } \\
\text { undang-undang, jual beli tersebut tidak sah, sebab sebagaimana UU darurat Nomor } \\
\text { 1/1952 jo UU } 24 \text { tahun } 1952 \text { jo UU } 76 / 1957 \text { menyatakan bahwa pemindahan mengenai } \\
\text { tanah dan barang yang mempunyai titel menurut hukum Eropa, hanya dapat dilakukan } \\
\text { setelah mendapat izin dari Menteri Kehakiman } \\
\text { sehingga keluarnya Sertipikat Hak Milik a.n. Raden Soeryo harus dibatalkan karena dia } \\
\text { tidak menghuni, karena ini bertentangan dengan Pasal } 53 \text { ayat } 2 \text { a UU Nomor } 5 \text { Tahun } \\
1986\end{array}$} \\
\hline \multicolumn{2}{|c|}{$\begin{array}{l}\text { menimbang bahwa dari pertimbangan diatas sertipikat Hak Milik Nomor } 341 / \text { Lebakgede tahun } \\
1990 \text { (Penggugat } 1 \text { ) haruslah dibatalkan oleh putusan Pengadilan Tata Usaha Negara } \\
\text { Bandung tanggal } 9 \text { Desember } 1993 \text { haruslah dikuatkan }\end{array}$} \\
\hline \multicolumn{2}{|c|}{$\begin{array}{l}\text { Pertimbangan Hukum } \\
\text { bahwa putusan Judex Factie sudah tepat yaitu tidak salah menerapkan atau melanggar hukum } \\
\text { yang berlaku }\end{array}$} \\
\hline \multicolumn{2}{|c|}{$\begin{array}{l}\text { mengadili: } \\
\text { 1. menolak permohonan kasasi dari Kepala Kantor Kota Bandung dan R. Soeryo } \\
\text { 2. mengabulkan gugatan penggugat /terbanding terhadap Tergugat } 1 \text { seluruhnya } \\
\text { menyatakan batal Sertipikat Hak Milik Nomor } 341 / \text { Lebakgede di Jalan Ir, H. Juanda, Surat Ukur } \\
\text { tanggal } 5 \text { April } 1965\end{array}$} \\
\hline \multicolumn{2}{|c|}{ B. Putusan Peradilan Umum } \\
\hline & \\
\hline
\end{tabular}




\section{Tingkat Pertama}

Pertimbangan Hukum

1. menimbang, bahwa oleh karena status rumah/persil sengketa adalah hak eigendom termasuk tanah yang mempunyai titel menurut hukum Eropa, maka pemindahan hak atas rumah/persil sengketa tersebut harus memenuhi peraturan-peraturan yang berlaku pada waktu itu

\section{a. Kitab Undang-Undang Hukum Perdata}

b.Undang-Undang Nomor 24 Tahun 1954 jo Pasal 76 Tahun 1957

c. menimbang, karena masalah jual beli rumah/persil sengketa dibuat pada tanggal 12 Nopember 1956, maka pengadilan dan memeriksa dan mengadili bukan didasarkan atas ketentuan Undang-Undang Nomor 5 Tahun 1960 (UUPA) dan peraturan pelaksanaannya, namun didasarkan pada Kitab Undang-Undang Hukum Perdata

2. menimbang bahwa pasal-pasal yang menyangkut pemindahan hak atas tanah dalam perkara ini adalah Pasal 1457 Kitab Undang-Undang Hukum Perdata, Pasal 1458 Kitab Undang-Undang Hukum Perdata, Pasal 1459 Kitab Undang-Undang Hukum Perdata dan Undang-Undang Nomor 24 Tahun 1954

3. menimbang, bahwa jual beli tanah/benda tetap dalam Kitab Undang-Undang Hukum Perdata, setelah dibuat persetujuan jual beli tanah antara pihak-pihak, maka secara hukum jual beli tersebut telah sah, tapi hak atas tanah tersebut tidaklah seketika berpindah dari penjual kepada pembeli, harus ada peraturan hak yaitu penyerahan (levering) atas tanah tersebut, berbeda dengan ketentuan dalam UUPA, setelah dibuat persetujuan jual beli tanah, hak atas tanah beralih dari penjual kepada pembeli (tunai dan terang).

4. Maka dalam hal ini harus ada memenuhi Pasal 2 UU Nomor 24 Tahun 1954, sebelum dilakukan penyerahan (levering) untuk mewujudkan pemindahan hak atas tanah diharuskan pula setelah mendapat ijin dari Menteri Kehakiman/Agraria.

\section{Putusan}

1. eksepsi,menolak eksepsi Tergugat I, II dan IV tersebut

2. dalam provisi,mengablkan tuntutan provisi pada sub 1 dan sub 2 tersebut

- dalam pokok perkara, dalam konpensi:

1. mengabulkan gugatan para penggugat untuk sebagian

2. menyatakan secara hak para penggugat adalah penghuni yang sah atas rumah dan tanah sengketa tersebut

3. menyatakan para penggugat selaku penghuni dan selaku ahli waris almarhum Bonar Sitompul mempunyai prioritas utama untuk membeli atau untuk memiliki rumah dan persil tersebut

4. menyatakan batal/tidak berkekuatan hukum dan tidak sah

- akta jual beli tanggal 22 Nopember 1956 Nomor 113 yang dibuat Mr. Tan Eng Kiam, Notaris di Bandung

- konversi tanggal 5 April 1965

- ljin Pemindahan Hak dari Arend Van Leeuwen kepada H. Kuto Nasution yang diberikan oleh Menteri Agraria tanggal 14 Desember 1964

- Hak Guna Bangunan Nomor 417/Balubur atas nama Arend dan H. Kuto Nasution

- Sertipikat Hak Milik Nomor 451/Balubur yag telah diubah menjadi Hak Milik Nomor 341/Lebak Gede 
5. Menyatakan secara hukum bahwa persil tersebut adalah tanah yang berstatus di kuasai oleh negara

6. Memerintahkan pada Tergugat III untuk memberikan hak atas tanah persil tersebut kepada para penggugat sesuai permohonan yang diajukan oleh para penggugat

7. Menghukum para Tergugat untuk tunduk pada putusan ini

\section{Tingkat Banding}

Pertimbangan Hukum

1. Jual beli rumah/persil sengketa antara Arend Van Leeuwen (penjual) dengan CV Wangidjaya Trading Coy (Pembeli) pada tanggal 22 Nopember 1956 secara hukum adalah sah, karena telah memenuhi ketentuan pasal 1457, 1458 Kitab Undang-Undang Hukum Perdata akan tetapi pemindahan hak baru terjadi setelah adanya penyerahan /levering atas rumah / persil sengketa, sebelum levering harus mendapat ijin Menteri Kehakiman (Menteri Agraria), dan ijin itu tekah dipenuhi berdasarkan SK Menteri Agraria tanggal 14 Desember 1964 No. SK 11/130/P.H/64.

2. Menimbang bahwa jual beli tersebut tidak pernah dibatalkan oleh para pihak ataupun adanya putusan hakim maka surat kuasa dari Arend Van Leeuwen tgl 28 November 1964 yang memberi kuasa kepada Nn. Makatulung dan Bonar Sitompul untuk menjual rumah persil/sengketa, disamping itu kalaupun Arend van Leeuwen memberikan hak-hak lain kepada para penggugat sesudah terjadi jual beli rumah merupakan perbuatan melawan hukum karena sudah tidak mempunyai alas hukum (rechtstitel) lagi sehingga perbuatanperbuatan hukum tersebut adalah tidak sah dan batal demi hukum dan pada waktu perkara ini diajukan ke Pengadilan, pemberi kuasa Arend van Leeuwen dan penerima kuasa $\mathrm{Nn}$ Makatulung dan Bonar Sitompul telah meninggal dunia sehingga menurut pasal 1813 KUHPer Surat Kuasa itu telah berakhir.

3. Jual beli rumah/persil sengketa, antara warga negara Belanda sebagai penjual dan warganegara Indonesia sebagai pembeli dimana jual belinya sebelum warganegara Belanda meninggalkan Indonesia maka rumah persil/sengketa bukan berstatus dikuasai oleh negara (bukan P3MB) atau bukan pula oleh Kepala Daerah

4. berdasarkan sertipikat HM No. 341 tgl 13 Oktober 1990 dan Akta Jual Beli No. 252/1973 tgl 16 Oktober 1973 membuktikan rumah/persil sengketa tersebut pemiliknya R.Soerjo Wirjohadiputro.

5. Surat ljin Perumahan dari Penggugat hanya meupakan Surat Keterangan Sementara yang dikeluarkan oleh Kantor Urusan Perumahan tgl 9 Mei 1964, sampai sekarang belum ada SIM sebagai tanda kepenghunian yang sah.

6. bahwa para penggugat telah bertahun-tahun menempati rumah/persil sengketa tersebut maka tentu harus ada hubungan sewa menyewa, namun dari fakta para penggugat tidak pernah membayar uang sewa, sehingga telah melakukan perbuatan wanprestasi

Putusan 
1.

membatalkan putusan PN Bandung

2. menolak tuntutan provisi para penggugat seluruhnya

3. dalam pokok perkara, mengabulkan gugatan penggugat dalam rekonpensi/tergugat I dalam konpensi untuk sebahagian

4.

menyatakan bahwa perbuatan para tergugat dalam rekonpensi adalah perbuatan melawan hukum

5.

Menyatakan penggugat dalam rekonpensi adalah sebagai pihak satu-satunya yang berhak atas tanah dan segala sesuatu yang berada di atasnya berdasarkan sertipikat HM No. 341/Lebakgede

6.

Memerintahkan para tergugat dalam rekonpensi untuk segera mengosongkan paviliun maupun ruangan-ruangan yang dihuninya tanpa hak.

\section{Tingkat Kasasi}

Pertimbangan Hukum

Judex Facti keliru menerapkan hukum mengenai keabsahan akta jual beli No. $113 \mathrm{tgl} 22$ November 1956 karena dilakukan tanpa izin Menteri Kehakiman (Menteri Agraria)

Judex Facti salah menerapkan hukum tentang Surat Keputusan Menteri Agraria tgl 14 Desember 1964 No. SK 11/130/PH/64, izin Menteri Agraria hanya dapat diberikan sebelum Akta Jual Beli Nomor 113 itu dilaksanakan

Judex Facti keliru menafsirkan tentang kuasa dari Arend Van Leewen tertanggal 28 November 1964 kepada Nona Makatulung dan

Bonar Sitompil, kuasa itu adalah sah dan tidak merupakan perbuatan melawan hukum

\section{Putusan}

1. Mengabulkan permohonan kasasi daripada pemohon kasasi Ny. Clara Mryon Lientje Tambunan CS

2. Mengabulkan gugatan penggugat untuk sebagian

3. Menyatakan secara hukum bahwa persil tersebut adalah tanah

yang berstatus dikuasai oleh negara

\section{f. $\quad$ C. Analisis Hasil Putusan}

1. Hakim Tingkat I dalam Peradilan TUN menimbang mengatakan bahwa masalah sengketa kepemilikan Peradilan Tata Usaha Negara tidak berwenang untuk memeriksa dan mengadilinya tetapi justru Hakim tingkat Banding dalam pertimbangan hukumnya masuk ke dalam wilayah sengketa kepemilikam yaitu memutuskan penggugat lebih berhak atas tanah sengketa berdasarkan kriteria Pasal 4 dan 5 UU Nomor 3 PRP Tahun 1960

2.Dasar Hukum yang digunakan dalam pemeriksaan perkara di Peradilan TUN adalah

- $\quad$ UU No.3 Prp tahun 1960

- $\quad$ PP No. 10 tahun 1961

- $\quad$ PP No. 223 tahun 1961 
3.Kesalahan intern BPN, bahwa tanah masih dalam sengketa pengadilan sudah diterbitkan se Sebaiknya permohonan yang masih dalam sengketa dijadikan tunggakan.

4. Hakim Peradilan Umum menggunakan ketentuan dalam Kitab Undang-Undang Hukum Perdata terhadap jual beli tersebut dengan alasan terjadinya jual beli sebelum berlakunya ketentuan UUPA, dalam KUHPer jual beli harus diikuti dengan penyerahan/levering, dan sebelum levering dilakukan harus ada ijin dari Menteri Kehakiman (Agraria) padahal SK Menteri Agraria tentang ijin pemindahan hak diberikan tanggal 14 desember 1964, yang berarti setelah berlakunnya UUPA, sehingga hakim disini tidak konsisten dalam menerapkan hukum, karena di satu sisi jual belinya menggunakan KUHPer, sedangkan levering/penyerahan itu terjadi setelah berlakunya UUPA berarti seharusnya menggunakan ketentuan UUPA.Dalam UUPA, jual beli mengadopsi hukum adat yaitu dilaksanakan secara terang dan tunai, berarti setelah adanya jual beli, hak atas tanah langsung beralih kepada pembeli.

5. Dasar hukum/peraturan yang digunakan dalam Peradilan Umum disini adalah UU No. 24 tahun 1954 tentang Pemindahan Hak Tanah dan Barang Tetap yang mempunyai titel menurut hukum Eropa, Pasal 1457, 1458 dan 1459 KUHPer

6. Majelis Hakim tingkat banding berpendapat Surat Izin Menghuni (SIM) hanya merupakan surat keterangan sementara yang dikeluarkan oleh Kantor Urusan Perumahan, dalam praktek untuk obyek tanah P3MB, SIM adalah salah satu bukti alas hak sepanjang SIM nya masih berlaku dan diperpanjang oleh Pemda dalam hal ini Kantor Urusan Perumahan.

\begin{tabular}{|l|l|}
\hline Nomor Urut & 2 \\
\hline Lokasi Kasus & Kota Samarinda Propinsi Kalimantan Timur \\
\hline $\begin{array}{l}\text { Pihak yang } \\
\text { bersengketa }\end{array}$ & $\begin{array}{l}\text { 1. Penggugat : Achmad Ibramsyah Bin Iberahim } \\
\text { 2. Tergugat : Kepala Kantor Pertanahan Samarinda }\end{array}$ \\
\hline Jenis Sengketa & Sengketa Warisan \\
\hline Duduk Perkara
\end{tabular}

1. Bahwa Penggugat adalah anak tunggal Iberahim (alm) dari Ibu Ratna Fatimah (cerai hidup). Hajjah Sadariah binti H. Udar istri kedua alm. Ibrahim dan tidak dikarunia anak. Sesuai dengan penetapan Pengadilan Agama Samarinda No. 81/1990 tertanggal 4 April 1990 maka Penggugat dan $\mathrm{Hj}$. Sadariah binti $\mathrm{H}$. Udar adalah ahli waris sah alm Ibrahim.

2. Bahwa selain meninggalkan ahli waris yaitu penggugat dan $\mathrm{Hj}$. Sadariah binti h. Udar, Alm Iberahim meninggalkan harta warisan berupa sebidang tanah berikut bagian (toko) terletak di Jl. Panglima Batur III Nomor SK 7/23 Nomor : 14 Kampung Pelataran, Kecamatan Samarinda llir, Samarinda sesuai dengan keputusan musyawarah angka romawi III huruf DJ, tanggal 11 Nopember 1979.

3. Bahwa harta warisan tersebuit diatas berasal dari pembagian/pemecahan harta warisan Alm. $\mathrm{H}$ Iberahim (Kakek penggugat) dimana sesuai keputusan musyawarah tanggal 11 Nopermber 1979 pusaka $\mathrm{H}$. Iberahim (alm) diantara para ahli waris dimana ayah penggugat mendapat harta warisan pada point 2 (dua) tsb diatas dan dikuatkan oleh putusan pengadilan No : 79/Pdt.G/1990/PN. Smda dan putusan mana telah berkekuatan hukum tetap, oleh karenanya secara hukum tanah dan bangunan tsb adalah harta warisan/peninggalan Alm. Iberahim. 
4. Bahwa antara penggugat dengan ibu tiri penggugat yang selama ini tinggal dan menetap di Jakarta tidak pernah ada komunikasi dan ketika penggugat berkehendak melakukan/pemecahan/ pembagian harta warisan Alm. Iberahim, ternyata telah diterbitkan sertifikat hak milik oleh tergugat tanpa sepengetahuan dan seizin tergugat.

5. Bahwa tanah warisan/peninggalan Alm. Iberahim tsb diatas telah diterbitkan sertifikat hak milik oleh tergugat atas nama $\mathrm{Hj}$. Sadariah Binti $\mathrm{H}$. Udar dengan nomor 1124 tanggal 30 Oktober 2001.

6. Bahwa didalam keputusan tergugat mengenai pemberian hak atas tanah tsb diatas tergugat hanya memberikan dan mencantumkan Hj. Sadariah Binti H. Udar sebagai pemegang hak atas tanah, padahal menurut hukum harus pula mencantumkan dan memberikan penggugat bersama-sama dengan $\mathrm{Hj}$. Sadariah sebagai pemegang hak atas tanah, oleh karenanya perbuatan tergugat tsb bertentangan dengan peraturan perundang-undangan yang berlaku dan karenanya batal.

7. Bahwa sertifikat hak milik Nomor 1124 semula atas nama $\mathrm{Hj}$. Sadariah Binti $\mathrm{H}$. Udar selanjutnya dibalik nama ke Haus Timotius berdasarkan akta jual beli nomor 498/SMDA llir XI/1996 tanggal 14 Nopember 1996 yang dibuat oleh Maruli Sitanggang S.H PPAT Kotamadya Samarinda

\section{Putusan Peradilan Tata Usaha Negara}

\section{Tingkat Pertama}

Pertimbangan Hukum

1. Eksepsi tergugat menyatakan bahwa gugatan adalah sudah kadaluarsa atau telah lewat waktu, sesuai pasal 32 ayat (2) Peraturan Pemerintah No. 24/thn 1997 tentang Pendaftaran Tanah, sertifikat yang telah diterbitkan secara sah yang memperoleh tanah tsb dengan itikad baik, namun ada pihak lain yang merasa mempunyai hak atas tanah tsb apabila dalam jangka waktu 5 (lima) tahun sertifikat tsb telah diterbitkan dan tidak ada yang mengajukan gugatan ke pengadilan, maka yang bersangkutan tidak dapat lagi untuk menuntut haknya, eksepsi tergugat ditolak dengan pertimbangan hakim.

2. Bahwa meskipun objek tanah yaitu sertifikat hak milik no. 1124 atas nama $\mathrm{Hj}$. Sadariah Binti H. Udar diterbitkan pada tanggal 30 Oktober 1996, akan tetapi pihak tergugat bukanlah merupakan pihak yang digugat secara langsung oleh Surat Keputusan tsb, sehingga tergugat waktu untuk dapat mengajukan gugatan sebagaimana dimaksudkan dalam pasal 55 Undang-Undang Nomor 5 tahun 1986, haruslah dipastikan secara kasusistis, yaitu sejak penggugat mengetahui kalau dirinya tidak tercantum sebagai pemegang hak atas tanah bersama H.j Sadariah Binti H. Udar didalam sertifikat hak milik No. 1124 sebagaimana obyek sengketa adalah pada tanggal 28 Oktober 2001 sementara itu penggugat pada tanggal 20 Desember 2001 telah mendaftarakan gugatannya ke Pengadilan Tata Usaha Negara Samarinda.

3. Menimbang bahwa bukti peraturan Pengadilan Agama Samarinda No.8/1990 tgl 14 April 1990 mengenai penetapan ahli waris yang digunakan $\mathrm{Hj}$. Sadariah Binti Udar sebagai pemohon telah dicantumkan antara lain mengatakan "Bahwa ahli waris sah dari almarhum Iberahim Bin H. Berahim adalah Hj. Sadariah Binti H. Udar selaku isteri dari Achmad Iberamsyah Bin Iberahim selaku anak". 
4.Menimbang bahwa ternyata dalam sertifikat hak milik Nomor 1124 oleh Tergugat tidak dicantumkan nama penggugat bersama-sama dengan $\mathrm{Hj}$. Sadariah Binti H. Udar sebagai pemegang hak atas tanah yang merupakan warisan almarhum Iberahim.

\section{Putusan}

1. Mengabulkan gugatan penggugat.

2. Menyatakan batal surat keputusan Tata Usaha Negara yang berupa sertifikat Hak Milik No. 1124 BS No. 4764/96 atas nama Hj. Sadariah Binti H. Udar tanggal 30 Oktober 1996 yang diterbitkan tergugat dan sekarang beralih atas nama Haus Timotius.

3. Memerintahkan tergugat untuk mencabut Surat Keputusan Tata Usaha Negara sebagaimana dimaksud diatas.

\section{Tingkat Banding}

Pertimbangan Hukum

1. Bahwa permohonan banding dari kuasa hukum tergugat/pembanding telah digunakan dalam tenggang waktu dan menurut cara-cara yang telah diatur dalam peraturan perundangundangan yang berlaku, karenanya menurut hukum permohonan banding tsb dapat diterima.

2. Bahwa Majelis Hakim Pengadilan Tinggi Tata Usaha Negara Jakarta telah memperhatikan memori banding dari tergugat/pembanding yang disampaikan kuasa hukumnya untuk disertifikatkan dalam putusan ditingkat banding.

3. Bahwa gugatan penggugat adalah sudah kadaluarsa (lewat waktu).

4. Bahwa pengadilan Tata Usaha Negara Samarinda menolak eksepsi tergugat aqno dengan pertimbangan pengugat baru mengetahui kalau dirinya tidak tercantum sebagai penggugat hak atas tanah bersama dengan $\mathrm{Hj}$. Sadariah Binti $\mathrm{H}$. Udar dengan sertifikat Hak Milik No. 1124, sebagaimana dalam gugatan penggugat sebagai obyek sengketa adalah pada yang berlaku tanggal 28 Oktober 2001 sementara itu penggugat pada tanggal 26 Desember 2001 telah mengajukan gugatanya ke PTUN Samarinda meskipun terbit sertifikat hak milik tsb pada tanggal 30 Oktober 1996 akan tetapi pihak penggugat bukanlah merupakan pihak yang ditunjuk secara langsung oleh surat keputusan tsb sehingga tenggang waktu untuk dapat diajukan gugatan dimaksud oleh pasal 55 UU No.5/1986 tentang PTUN haruslah dipertimbangkan secara kausistis.

5. Bahwa menurut pendapat Majelis hakim Pengadilan Tinggi TUN Jakarta sertifikat Hak Milik No. 1124 atas nama Hj. Sadariah Binti H. Udar yang menjadi obyek sengketa dalam perkara ini telah diterbitkan secara sah atas nama yang bersangkutan berdasarkan bukti-bukti adalah merupakan dasar-dasar utama dan sahnya tentang adanya Keputusan TUN untuk mengabulkan permohonan-permohonan $\mathrm{Hj}$. Sadariah Binti $\mathrm{H}$. Udar atas bidang tanah yang

dimohon sehingga dengan menunjuk Pasal 32 PP 24/ 97 tenmtang pendaftaran tanah beserta pelaksanaannya maka sertifikat Hak Milik No. 1124 /Desa Kelurahan Pelabuhan, Jl. Panglima Batur, Surat Ukur/Gambar Situasi No. 4764/1996 tanggal 30 Oktober 1996 berdasarkan SK. Kakanwil-BPN Prop. Kaltim Nomor SK 11/Hak SMR/II/BPN16/07/PP.10/1996-1997/1996 tanggal 30 Oktober 1996 sehingga dengan sertifikat/Buku Hak 
Milik No. 1124 atas nama Hj. Sadariah Binti H. Udar sehingga pihak lain dalam hal ini penggugat/terbanding secara hukum tidak dapat lagi penggugat menggugat sejak diterbitkannya sertifikat aqno pada tanggal 30 Oktober 1996 telah lewat 5 (lima) tahun yakni penggugat baru menggunakan gugatan pada tanggal 20 Desember 2001 Nomor 17/6,TUN/2001/TNH/PTUN-SMD karena dari tanggal 30 Oktober 1996 s/d 20 Desember 2001 telah lewat waktu 5 (lima) tahun dengan demikian keabsahan atas penggugat/gugatan oleh penggugat tidak dapat mencapai dasar hukum lagi.

6. Bahwa Majelis Hakim PTUN Jakarta berpendapat sertifikat Hak Milik No. 1124 Surat Ukur/Gambar Situasi No.4764/1996 tanggal 30 Oktober 1996 a.n. Hj. Sadariah Binti H. Udar diterbitkan tidak bertentangan dengan peraturan perundang-undangan yang berlaku, tidak diterbitkan dengan menyalahgunakan wewenang ataupun tidak pula ditertbitkan secara sewenang-wenang ataupun melanggar azas-azas hukum pertanahan yang baik sehingga tergugat/terbanding sebagai pejabat Tata Usaha Negara secara sah dan berwenang dalam membentuk Keputusan Tata Usaha Negara/Obyek Sengketa tanah perkara ini. Bahwa selanjutnya atas dasar kebenaran surat bukti T-14 dan T-15 berupa akta jual beli No. 438/SMDA. ILIR./XD/1996 tanggal 11 Nopember dan berupa akta tahunan perjanjian jual-beli tanggal 24 Pebruari 1996, Majelis Hakim TUN Jakarta berpendapat peralihan hak Milik dari pemilik asal $\mathrm{Hj}$. Sadariah Binti H. Udar kepada Haus Timotius atas dasar Surat/Akta Jual-Beli tsb, menurut hakim adalah juga sah dan pemilik baru Tuan Haus Timotius telah secara nyata menguasai sebidang tanah, sehingga atas bidang tanah yang telah ada sertifikatnya tsb secara sah atas nama Haus Timotius tidak dapat diganggu gugat lagi oleh siapapun.

\section{Putusan}

1. Menerima permohonan banding dari tergugat/pembanding.

2. Membatalkan Putusan Pengadilan Tata Usaha Negara Samarinda No.17/6,TUN/2001/TNH/PTUN-SMD tanggal 27 Maret 2002

\section{Analisa Hasil Putusan}

1. Dasar Hukum yang digunakan dalam pemeriksaan perkara di Peradilan TUN adalah :

- Undang-undang Nomor 5 Tahun 1986;

- Pasal 18 PP. Nomor 10 Tahun 1961 butir 4;

- PP. 24 tahun 1997

2. Hakim Tingkat Pertama dalam Peradilan TUN dalam pertimbangan hukumnya masih menggunakan Peraturan Pemerintah Nomor 10 Tahun Tahun 1961, pada tingkat banding pada memori banding Pembanding menolak pertimbangan hukum Hakim tarsebut, karena Peraturan Pemerintah Nomor 10 Tahun 1961 tersebut sejak tanggal 8 Juli 1997 dinyatakan tidak berlaku lagi dan telah diganti dengan Peraturan Pemerintah Nomor 24 Tahun 1997.

3. Bahwa gugatan adalah sudah kadaluarsa atau telah lewat waktu, sesuai pasal 32 ayat (2) Peraturan Pemerintah No. 24/thn 1997 tentang Pendaftaran Tanah, sertifikat yang telah diterbitkan secara sah apabila dalam jangka waktu 5 (lima) tahun sertifikat tsb telah diterbitkan dan tidak ada yang mengajukan gugatan ke pengadilan (K3)

4. Hakim Tingkat Kasasi dalam Peradilan Umum menimbang Bahwa putusan Judex Facti salah menerapkan hukum karena telah melanggar pasal 5 UUPA dengan pertimbangan 
hukumnya (putusan Pengadilan Negeri Samarinda tersebut), padahal pasal 5 UUPA menyatakan : Hukum Agraria yang berlaku atas bumi, air dan ruang angkasa adalah Hukum Adat, hal mana dapat diketemukan pula pada konsideran UUPA pada Sub A yang berbunyi : "bahwa berhubung dengan apa yang tersebut dalam pertimbangan-pertimbangan di atas perlu adanya Hukum Agraria Nasional", yang berdasarkan Hukum Adat tentang tanah, demikian juga hal ini terdapat pada memori penjelasan UUPApada angka III sub 1 . yang menyatakan : "oleh karena rakyat Indonesia sebagian besar tunduk pada Hukum Adat" maka Hukum Agraria yang baru tersebut akan didasarkan pula pada ketentuan-ketentuan Hukum Adat itu. Dengan demikian, oleh karena Hukum Tanah yang berlaku adalah Hukum Adat sedangkan Hukum Adat tidak mengenal daluwarsa, maka sudah

selayaknya putusan Judex Facti yang mempertimbangkan adanya kedaluwarsaan sebagiaan dipertimbangkaan pada putusan Pengadilan Negeri Samarinda, haruslah merupakan putusan yang dibatalkan.

\begin{tabular}{|c|c|}
\hline $\begin{array}{l}\text { Nomor } \\
\text { Urut }\end{array}$ & 3 \\
\hline $\begin{array}{l}\text { Lokasi } \\
\text { Kasus }\end{array}$ & Kota Padang Propinsi Sumatera Barat \\
\hline & $\begin{array}{l}\text { Penggugat = Eddy Sukamto alias Tjiang Sen Kiat } \\
\text { Tergugat I = Kepala Kantor Pertanahan Kota Padang }\end{array}$ \\
\hline $\begin{array}{l}\text { Jenis } \\
\text { Sengketa }\end{array}$ & Sengketa Kepemilikan \\
\hline \multicolumn{2}{|c|}{ Duduk Perkara } \\
\hline \multicolumn{2}{|c|}{$\begin{array}{l}\text { 1. Tergugat tanpa menelusuri asal-usul tanah serta tanpa memperhatikan keberatan dari } \\
\text { penggugat menerbitkan sertipi-kat balik nama yang dimohon Hendra Yuliady. Karenanya, } \\
\text { ber-alasan hukum apabila penggugat mohon PTUN membatalkan sertipikat sebagai obyek } \\
\text { perkara a Quo. }\end{array}$} \\
\hline \multicolumn{2}{|c|}{$\begin{array}{l}\text { 2. Setelah mempertimbangkan gugatan, jawaban, bukti dan kesimpulan dari para pihak } \\
\text { ditemukan fakta yuridis sebagai berikut: } \\
\text { bahwa dalam persidangan pemeriksaan setempat telah terbukti setengah dari tanah berikut } \\
\text { bangunan yang di-maksud dalam sertipikat masih berada di bawah pengua-saan } \\
\text { penggugat; } \\
\text { bahwa terbukti pula dalam persidangan pemeriksaan setempat, tanah dan bangunan yang } \\
\text { dimaksud dalam sertipikat merupakan bagian yang tidak terpisahkan dari keseluruhan } \\
\text { tanah dan bangunan; } \\
\text { bahwa dari bukti penggugat diperoleh fakta jauh sebelum terjadinya proses balik nama } \\
\text { sertipikat HGB, penggugat telah mengajukan keberatan kepada tergugat supaya proses } \\
\text { balik nama sertipikat HGB yang dimohon Hendri Yuliady ditangguhkan pelaksanaannya } \\
\text { karena tanah ter-sebut secara yuridis formal dan materiil masih tetap dikuasai oleh } \\
\text { penggugat; } \\
\text { bahwa untuk menanggapi keberatan penggugat tersebut, tergugat melalui surat tanggal } 14 \\
\text { November } 1997 \text { telah membalas surat penggugat yang pada pokoknya menyatakan } \\
\text { bahwa penangguhan permohonan balik nama sertipikat HGB hanya bisa dilaksanakan } \\
\text { apabila penggugat mengajukan gugatan melalui pengadilan yang tembusannya } \\
\text { disampaikan kepada tergugat; }\end{array}$} \\
\hline
\end{tabular}


bahwa untuk menindaklanjuti isi surat tergugat tersebut maka penggugat mengajukan gugatan perdata di PN Padang, yang mana setelah adanya gugatan dimaksud kemudian penggugat mengirimkan surat kepada tergugat yang pada pokoknya mohon kembali penangguhan proses balik nama atas sertipikat HGB No. 424/Kampung Alang Lawas dengan penegasan bahwa atas tanah tersebut saat ini terjadi sengketa keperdataan di PN Padang;

bahwa ternyata kendatipun sudah ada keberatan dari penggugat serta adanya protes surat menyurat antara penggugat dan tergugat menyangkut proses balik nama, namun dalam kenyataan tergugat tetap pada sikapnya yang menindaklanjuti proses balik nama sertipikat HGB No. 424/Kampung Alang Lawas sampai diterbitkannya sertipi-kat sebagai obyek perkara;

bahwa dalam memproses balik nama, tergugat tidak secara cermat melakukan penelitian demi kelengkapan administrasi atas proses balik nama sertipikat dimaksud, hal mana terbukti dari penegasan tergugat bahwasanya dalam proses balik nama pernah melakukan penelitian atas asal-usul tanah serta pengecekan secara fisik dari tanah berikut bangunan yang dimaksud dalam sertipikat sebagai obyek perkara, bahkan mengenai keberadaan akta jual beli antara Lianyta dengan Hendra Yuliady yang patut diragu-kan keabasahannya, juga tidak pernah dipertanyakan oleh tergugat;

bahwa ternyata akta jual beli antara Lianyta dengan Hendra Yuliady secara yuridis formal dapat ditafsirkan sebagai per-buatan hukum yang tidak sempurna karena akta jual beli tersebut sesungguhnya didasari dari akta kuasa yang dianalogikan sebagai kuasa mutlak yang bertentangan dengan instruksi Mendagri No.14 Tahun 1982. Namun hal ini tidak pernah diteliti tergugat;

Bahwa dari bukti tergugat secara eksplisit terlihat dimana keberatan penggugat untuk penangguhan proses balik nama telah terlebih dahulu diajukan dan diterima oleh tergugat sebelum sampai pada pelaksanaan jual beli antara Lianyta dengan Hendra Yuliady serta proses balik nama yang dilakukan intern tergugat sendiri, namun hal ini tidak diperhatikan tergugat yang seharusnya perlu diperhatikan sebagai tindakan faktual untuk menjamin kepastian hukum dan kecermatan dalam pengambilan keputusan.

\section{A. Putusan Peradilan Tata Usaha Negara}

\section{Tingkat Pertama}

Pertimbangan Hukum

Menimbang dari fakta yuridis di atas, majelis akan mengkaji dan menilai apakah dari fakta yuridis dapat terbukti dalil gugatan penggugat sehingga sertipikat sebagai obyek perkara harus dibatalkan;

Menimbang dari ketentuan Pasal 53 UU No. 5 Tahun 1986 maka secara limitatif telah disebutkan alasan-alasan yang dapat diguna-kan dalam gugatan guna memohon pembatalan suatu Keputusan TUN, yaitu antara lain: Keputusan TUN yang digugat bertentangan dengan UU tersebut;

Menimbang bahwa selain dari dasar-dasar pengujian sebagaimana tersebut dalam Pasal 53 Ayat (2) di atas maka pengujian secara hukum terhadap prosedural penerbitan suatu keputusan TUN dapat pula ditinjau dari segi kebenaran menurut nilai-nilai yang terkan-dung 
dalam Asas-Asas Umum Pemerintahan yang Baik (AAUPB) sebagai salah satu instrumen yuridis bagi tiap pejabat atau Badan TUN untuk dijadikan sebagai norma yang patut dipedomani dalam pengambilan suatu kebijaksanaan termasuk bila hendak menerbitkan suatu keputusan TUN;

Menimbang bahwa dalam ketentuan Pasal 45 Ayat (1) huruf c PP No. 24 Tahun 1997 sebagai peraturan penyempurnaan dari PP No. 10 Tahun 1961 secara atributif telah ditentukan bahwa salah satu syarat bagi Kepala Kantor Pertanahan untuk menolak melakukan pendaftaran peralihan atau pembebanan hak jika dokumen yang diperlukan untuk pendaftaran peralihan hak yang bersangkutan tidak lengkap;

Menimbang lebih lanjut dalam PP No. 24 Tahun 1997 khususnya Pasal 59 Ayat (2) disebutkan bahwa penerbitan sertipikat pengganti sebagaimana dimaksud pada Ayat (1) didahului dengan pengumu-man satu kali dalam salah satu surat kabar harian setempat atas biaya pemohon;

Menimbang bahwa pada ketentuan pasal tersebut di atas, hakim berpendapat adalah relevan untuk dijadikan normatif yang patut dipedomani untuk menguji prosedural penerbitan sertipikat in litis, oleh karena dalam melakukan suatu perbuatan hukum publik, tidaklah semata terpaku kepada peraturan yang bersifat sempit penafsirannya, akan tetapi lebih jauh daripada itu justru harus pula memperhatikan kemungkinan adanya ketentuan yang relevan untuk dipertimbangkan;

Menimbang bahwa dari fakta yuridis secara eksplisit terlihat dimana tergugat dalam menerbitkan sertipikat in litis disamping tidak secara cermat melakukan penelitian kelengkapan administrasi dari data yang dibutuhkan terhadap proses balik nama dan penggantian blanko sertipikat sebagai obyek perkara antara lain dibuktikan dari sikap tergugat yang tidak mempertanyakan eksistensi dari legalitas akta jual beli dimaksud sedangkan pada sisi lain tergugat juga tidak pernah melakukan penelitian secara fisik atas tanah tersebut, baik mengenai asal-usul tanah maupun terhadap penguasaan tanah;

Menimbang bahwa tergugat dalam melakukan penggantian nomor dan blanko sertipikat sebagai obyek perkara tidak pernah mengu-mumkan perihal penggantian sertipikat dimaksud di surat kabar harian yang sangat penting sebagai upaya preventif untuk mence-gah timbulnya sengketa di kemudian hari, bahkan lebih jauh walau penggugat telah mengajukan keberatan namun tergugat tidak memperhatikan dan tetap menerbitkan sertipikat yang dimohon Hendra Yuliady;

Menimbang bahwa selanjutnya PP No. 24 Tahun 1997 mengatur: Pasal 37 Ayat (1), Pasal 38 Ayat (1) dan Pasal 39 Ayat (1);

Menimbang bahwa dalam bagian pertama Instruksi Mendagri No. 14 Tahun 1982 ditentukan pula bahwa melarang camat dan kepala desa atau pejabat yang setingkat dengan itu untuk membuat/ menguatkan pembuatan surat kuasa mutlak yang pada hakekatnya merupakan pemindahan hak atas tanah;

Menimbang bahwa dengan memperhatikan perundang-undangan di atas, tergugat dalam menerbitkan sertipikat tidak secara sem-purna meneliti data yuridis yang menjadi salah satu syarat dikabul-kannya permohonan balik nama sertipikat dimana tergugat menaf-sirkannya 
didasari atas surat kuasa mutlak yang menurut hukum tidak diperbolehkan lagi bahkan apabila hal itu tetap dilakukan maka perbuatan hukum yang didasari atas surat kuasa mutlak ter-sebut akan dinyatakan batal atau cacat hukum (lihat dan banding-kan dengan putusan MARI No. $1991 \mathrm{~K} / \mathrm{Pdt} / 1994)$ oleh karenanya Maka penerbitan sertipikat oleh tergugat bertentangan dengan Pasal 37 Ayat (1); Pasal 38 Ayat (1); dan Pasal 39 Ayat (1) huruf d PP No. 24 Tahun 1997 serta bertentangan dengan Instruksi Mendagri No. 14 Tahun 1982;

Menimbang bahwa ketentuan PP No.24 Tahun 1997 relevan untuk dipertimbangkan dalam memutus perkara a quo, oleh karena sebelum diterbitkannya sertipikat in litis oleh tergugat maka secara yuridis formal peraturan dimaksud sudah berlaku efektif dalam tatanan hukum agraria Indonesia;

Menimbang bahwa dengan memperhatikan berbagai pertimbangan tersebut di atas, maka hakim berpendapat bahwa penerbitan sertipikat HGB No. 135 a.n. Hendra Yuliady adalah bertentangan dengan perundang-undangan yang berlaku dan harus dinyatakan batal;

Menimbang bahwa oleh karena penerbitan sertipikat in litis bertentangan dengan perundangundangan maka alasan-alasan gugatan penggugat tidak memenuhi ketentuan Pasal 53 Ayat (2) huruf a UU No. 5 Tahun 1986;

Menimbang bahwa dari fakta yuridis tergugat dalam menerbitkan sertipikat tidak mengumpulkan data-data relevan serta tidak secara cermat mempertimbangkan adanya kepentingan penggugat yang nyata-nyata telah mengajukan keberatan kepada tergugat sehing-ga atas dasar ini hakim berpendapat bahwa penerbitan sertipikat in litis oleh tergugat bertentangan dengan AAUPB, khususnya asa kecermatan formal dan karenanya harus dibatalkan;

Menimbang bahwa seharusnya tergugat berpedoman pada pera-turan yang lebih tinggi yang dalam hal ini PP bukan dengan pera-turan lain di bawahnya (surat edaran menteri). Seharusnya, pera-turan surat edaran menteri/kepala BPN harus sejalan dengan peraturan yang lebih tinggi yang dalam hal ini PP No. 24 Tahun 1997

Putusan

1. Dalam eksepsi:

Menolak eksepsi tergugat seluruhnya

2. Dalam pokok perkara:

a. mengabulkan gugatan penggugat seluruhnya;

b. menyatakan batal sertipikat HGB No.135 Surat Ukur No.280 Tahun 1997 a.n. Hendra Yuliady;

c. memerintahkan kepada tergugat untuk segera mencabut kembali sertipikat HGB No.135 SU No.280 Tahun 1997 a.n. Hendra Yuliady;

d. menghukum tergugat untuk membayar biaya perkara

Tingkat Banding

Pertimbangan Hukum

Menimbang bahwa pernyataan permohonan banding oleh tergugat atau pembanding telah diajukan dalam tenggang waktu serta memenuhi syarat, oleh karenanya permohonan banding secara formil dinyatakan dapat diterima;

Menimbang bahwa maksud gugatan penggugat-terbanding pada pokoknya menuntut agar PTUN menyatakan sertipikat HGB No.135 SU No.280 Tahun 1997 a.n. Henra Yuliady batal 
dan tidak sah menurut hukum;

Menimbang bahwa alasan-alasan dari gugatan penggugat-terbanding tersebut adalah karena tergugat dalam menerbitkan SK tersebut tidak sesuai dengan perundang-undangan yaitu Surat Gubernur KDH Tingkat I Sumatera Barat No.593.2/4268;

Menimbang bahwa tergugat/pembanding dalam sengketa ini adalah hanya Kepala Kantor Pertanahan Kota Padang saja (padahal Hendra Yuliady mendapatkan tanah dari Lianyta);

Menimbang bahwa pihak lain yang berkepentingan (Blang-hesbende) terhadap sertipikat yang digugat tersebut adalah pemilik tanah sekarang Hendra Yuliady, namun tidak diikutsertakan sebagai pihak dalam sengketa ini, baik dengan menjadikannya selaku tergugat intervensi atau pihak yang berkepentingan maupun atas usaha hakim sebagaimana dimaksud pada Pasal 83 Ayat (1) UU No. 5 Tahun 1986. Demikian pula Lianyta dari siapa Hendra Yuliady memperoleh haka atas tanahnya menjadi pertimbangan pokok majelis hakim pengatilan tinggi TUN dalam memeriksa dan mengadili sengketa ini pada tingkat banding;

Menimbang pula bahwa dalam sengketa ini terjadi titik singgung masalah perdata dan masalah peraturan maka karena tidak diikutsertakan pihak yang berkepentingan yaitu Hendra Yuliady, Majelis Hakim Pengadila Tinggi TUN berpendapat sengketa ini tidak dapat diselesaikan secara tuntas;

Menimbang bahwa oleh karena itu, untuk memberi peluang bagi yang berkepentingan untuk membela haknya, gugatan penggugat-terbanding harus dinyatakan tidak dapat diterima;

Menimbang bahwa berdasarkan pertimbangan hukum tersebut di atas yaitu tidak diikutsertakannya Hendra Yuliady sebagai pihak yang berkepentingan dalam sengketa ini baik oleh penggugat-terbanding maka oleh karena itu putusan majelis hakim PTUN No.02/6/1998/PTUN-Padang tanggal 13 April 1998 tersebut tidak dapat lagi dipertahankan maupun oleh inisiatif hakim, dan haruslah dibatalkan.

\section{Putusan}

Mengadili:

1. menerima permohonan banding tergugat;

2. membatalkan putusan hakim PTUN No.02/6/1998/PTUN-Pdg tanggal 13 April 1998.

Mengadili sendiri:

1. Menolak eksepsi tergugat-pembanding

2. Menyatakan gugatan tidak dapat diterima (Niet Ontvankelijkver-klaard)

\section{Tingkat Kasasi}

Pertimbangan Hukum

1. Bahwa sengketa TUN adalah menyangkut keputusan yang diambil oleh Pejabat TUN, apakah keputusan tersebut sah atau tidak sehingga tidak tepat judex facti mengharuskan pihak lain supaya ikut digugat atau ditaris sebagai tergugat, justru kalau ada pihak yang merasa kepentingannya dirugikan dengan adanya gugatan tersebut maka pihak yang bersangkutan (1.c. Hendra Yuliady)lah yang justru harus melibatkan diri (intervensi) dalam perkara a quo;

2. Menimbang bahwa setelah mempelajari pertimbangan dalam putusan pengadilan TUN Padang secara seksama, maka MA sependapat sehingga MA mengambil alih dan diajdikan 
pertim-bangan sendiri;

3. Menimbang bahwa berdasarkan pertimbangan tersebut di atas menurut pendapat MA terdapat cukup alasan untuk mengabulkan permohonan kasasi yang diajukan oleh pemohon kasasi: Eddy Sukamto alias Tjang Sen Kiat tersebut dan membatalkan putusan PT TUN Medan tanggal 18 November 1998 No.32/BDG.6.PD/PT. TUN-MDN/1998 serta MA mengadili sendiri perkara ini.

Putusan

Mengadili:

1.Membatalkan permohonan kasasi dari pemohon kasasi Eddy Sukamto alias Tjang Sen Kiat tersebut;

2. Membatalkan putusan PT TUN Medan tanggal 18 November 1998 No.32/BDG.6PD/PT.TUNMDN/1998

Mengadili sendiri:

Dalam eksepsi:

Menolak eksepsi tergugat seluruhnya

8. Dalam Pokok perkara

Mengabulkan gugatan penggugat seluruhnya;

Menyatakan batal sertiikat HGB No.135 SU No.280 Tahun 1997 a.n. Hendra Yuliady;

Memerintahkan kepada tergugat untuk segera mencabut kembali sertipikat HGB No.135 SU No.280 Tahun 1997 a.n. Hendra Yuliady yang dinyatakan batal tersebut.

\section{B. Putusan Peradilan Umum}

\section{Tingkat Pertama}

Pertimbangan Hukum

Tidak Ada Data

Putusan

Mengadili:

Dalam eksepsi:

Menyatakan eksepsi tergugat A (Lianyta, cs) dan tergugat B (Hendra Yuliady) tidak dapat diterima.

Dalam konpensi:

1.Mengabulkan gugatan penggugat untuk sebagian;

2. Menyatakan batal demi hukum pengikatan jual beli No. 51 tanggal 23 November 1984;

3. Menyatakan akta jual beli No.73/JB/1985 tanggal 6 Maret 1985 batal demi hukum;

4. Menyatakan akta jual beli antara tergugat $A$ dan tergugat $B$ dan surat lain yang dibuat tergugat A dan tergugat $B$ sehubungan dengan obyek perkara batal demi hukum;

5. Menyatakan tergugat $B$ adalah pembeli yang tidak beritikad baik dan karena itu tidak perlu dilindungi oleh hukum;

6. Menyatakan bahwa HGB No.424 SU No.12/1956 tidak dibalik nama atas nama tergugat A cacad hukum;

7. Memerintahkan tergugat $\mathrm{C}$ (Kantor Pertanahan Kota Padang) untuk mencatat kembali HGB No.424 SU No.12/1956 a.n. penggugat;

8.Menolak gugatan yang lain dan selebihnya.

\section{Tingkat Banding}

Pertimbangan Hukum

Tidak Ada Data 


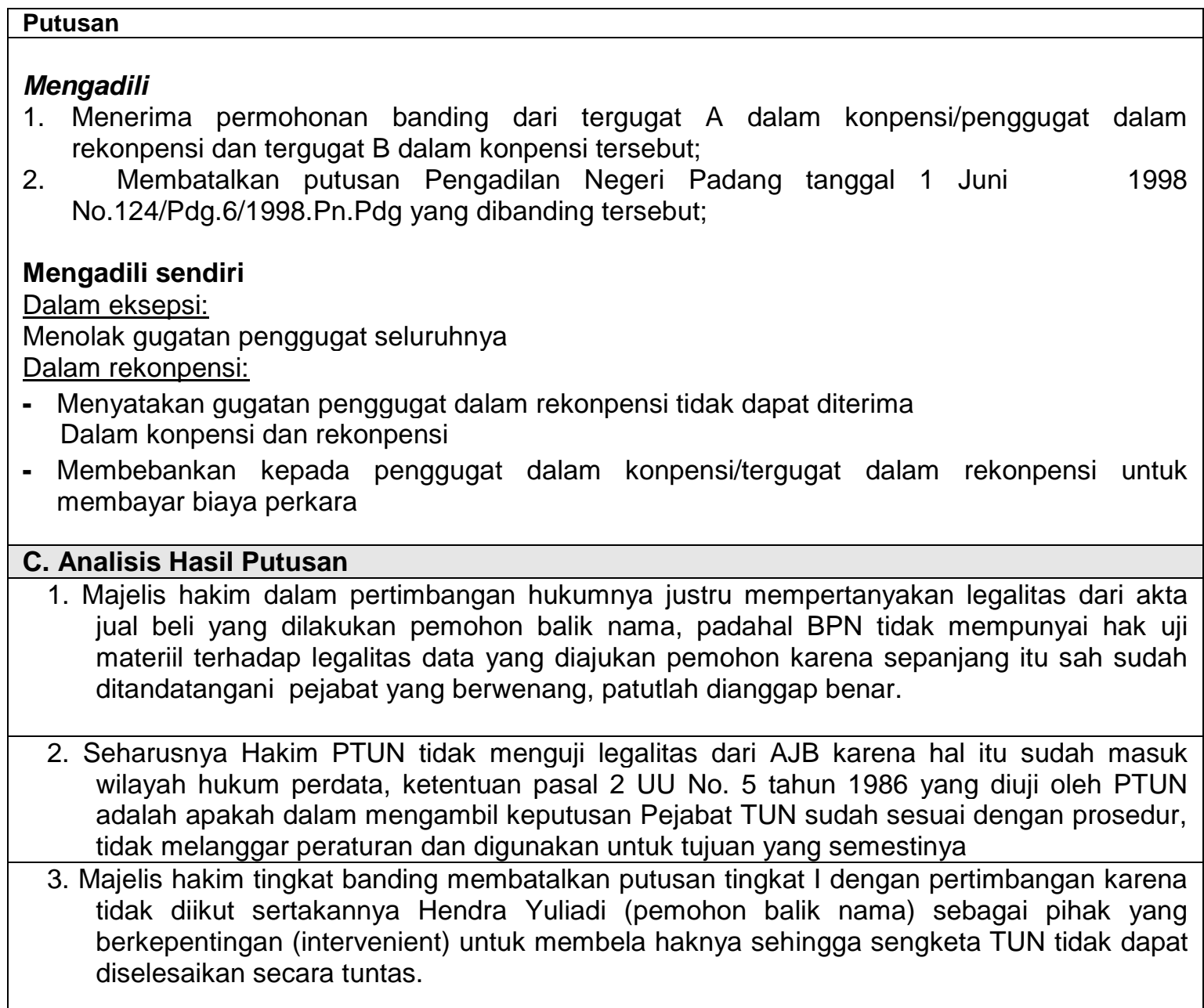

5. Sengketa TUN menyangkut keputusan yang diambil oleh pejabatTUN, yaitu apakah keputusan itu sudah sah sesuai dengan aturan sehingga tidak tepat majelis mengharuskan pihak lain supaya ikut digugat atau ditarik sebagai tergugat, kalau ada pihak yang merasa kepentingannya dirugikan dengan adanya gugatan tersebut maka pihak yang bersangkutan yang harus melibatkan diri (intervensi) dalam perkara a quo.

\begin{tabular}{|l|l|}
\hline $\begin{array}{l}\text { Nomor } \\
\text { Urut }\end{array}$ & 4 \\
\hline $\begin{array}{l}\text { Lokasi } \\
\text { Kasus }\end{array}$ & Kota Makasar Propinsi Sulawesi Selatan \\
\hline $\begin{array}{l}\text { Pihak } \\
\text { yang } \\
\text { bersengk } \\
\text { e ta }\end{array}$ & \begin{tabular}{l} 
1. Penggugat : Achmad Toappo \\
\hline A. Putusan Peradilan Tata Usaha Negara
\end{tabular} \\
\hline
\end{tabular}




\begin{tabular}{|c|c|}
\hline Tingkat $\mathrm{Pe}$ & ama \\
\hline Pertimbang & in Hukum \\
\hline Tidak Ada & ata \\
\hline Putusan & \\
\hline $\begin{array}{l}\text { Putusan Pe } \\
\text { No.18/G.TL } \\
\text {-Menyatak }\end{array}$ & $\begin{array}{l}\text { gadilan Tata Usaha negara tanggal } 25 \text { Oktober } 1993 \\
\text { V/1993/PTUN.UPG dalam amarnya, antara lain: } \\
\text { gugatan penggugat tidak dapat diterima }\end{array}$ \\
\hline Tingkat $\mathrm{Ba}$ & ding \\
\hline Pertimbang & in Hukum \\
\hline Tidak Ada & ata \\
\hline Putusan & \\
\hline $\begin{array}{l}\text { Putusan P } \\
\text { amarnya, a } \\
\text { 1. Mengab } \\
\text { 2. Menyata } \\
\text { 3. Memerir } \\
\text { Putusan } \mathrm{m}\end{array}$ & $\begin{array}{l}\text { ngadilan Tata Usaha negara tanggal } 3 \text { Mei } 1994 \text { No.03/Bdg.G.TUN/1994 dalam } \\
\text { tara lain: } \\
\text { kan gugatan penggugat } \\
\text { an Batal Sertipikat HGB No. } 115 \text { Tahun } 1986 \text { atas nama PT Timurama } \\
\text { ahkan kepada Tergugat untuk mencabut Sertipikat HGB No.115/1986. } \\
\text { mpunyai kekuatan hukum tetap. }\end{array}$ \\
\hline B. Putusar & Peradilan Umum \\
\hline $\begin{array}{l}\text { Pihak } \\
\text { yang } \\
\text { bersengk } \\
\text { e } \\
\text { ta }\end{array}$ & $\begin{array}{ll}\text { Penggugat : } & \text { PT Timurama } \\
\text { Tergugat }: & \text { - A. Ahmad Toappo } \\
& - \text { Najmiah Muin } \\
& - \text { Kepala Kantor Pertanahan Kota } \\
& \text { Pandang } \\
\end{array}$ \\
\hline Tingkat Pe & tama \\
\hline Pertimbang & n Hukum \\
\hline Tidak Ada & \\
\hline Putusan & \\
\hline $\begin{array}{l}\text { Putusan Per } \\
\text { lain: } \\
\text { - } \quad \text { Menyatal } \\
\quad \text { tetap me }\end{array}$ & $\begin{array}{l}\text { adilan Negeri Tanggal } 15 \text { Septenber No. 223/Pts.Pdt.G/1994/PN.UPG dalam amarnya antara } \\
\text { an GS tanggal } 24 \text { Desember } 1975 \text { da Sertipikat HGB No.115/Mangasa Tahun } 1986 \text { adalah } \\
\text { gikat secara sempurna }\end{array}$ \\
\hline Tingkat Ban & \\
\hline Pertimbang & n Hukum \\
\hline Tidak Ada & \\
\hline Putusan & \\
\hline $\begin{array}{l}\text { Putusan P } \\
\text { dalam ama } \\
\text {-Membatalk } \\
\text {-Memerinta }\end{array}$ & $\begin{array}{l}\text { gadilan Tinggi Ujung Pandang tanggal } 22 \text { April } 1996 \text { No. 39/Pdt/1996/ PT.UPG } \\
\text { lya, antara lain: } \\
\text { in putusan Penga-dilan Negeri } \\
\text { kan untuk meng-angkat sita jaminan atas obyek perkara }\end{array}$ \\
\hline Tingkat Ka & asi \\
\hline Pertimbang & n Hukum \\
\hline Tidak Ada I & \\
\hline Putusan & \\
\hline
\end{tabular}


antara lain:

- membatalkan putusan Pengadilan Tinggi Ujung Pandang tanggal 22 April 1996

- Menyatakan GS tanggal 24 Desember 1975 dan sertipikat HGB No.115/mangasa adalah tetap mengikat secara sempurna

\begin{tabular}{|l|l|}
\hline Nomor Urut & $\mathbf{5}$ \\
\hline $\begin{array}{l}\text { Kokasi } \\
\text { Pihak yang } \\
\text { bersengketa }\end{array}$ & $\begin{array}{l}\text { Kota Manado Propinsi Sulawesi Utara } \\
\text { Penggugat Intervensi = Ny. N. Irene Beatrix Lasut } \\
\text { Tergugat I = Kakanwil BPN Prop. Sulawesi Utara } \\
\text { Tergugat II= Kepala Kantah Kota Manado }\end{array}$ \\
\hline $\begin{array}{l}\text { Jenis } \\
\text { Sengketa }\end{array}$ & $\begin{array}{l}\text { Pembatalan Surat Keputusan Kepala Kantor Wilayah Badan Pertanahan Nasional Propinsi } \\
\text { Sulawesi Utara Tertangal 15 Januari 1996 Nomor: 01/HGB/ KWBPN/1996 oleh Tergugat I, } \\
\text { sertipikat HGB No: 06/Desa Tongkeina, GS Khusus tanggal 11-12-1995 No: 22/1995 an. } \\
\text { PT Sekawan Usaha Bhakti Nusa berkedudukan di Jakarta. }\end{array}$ \\
\hline \multicolumn{2}{|l|}{ Duduk Perkara } \\
\hline
\end{tabular}

1. bahwa Penggugat sangat berkeberatan sebab telah dirugikan kepentingannya akibat diterbitkannya/ dikeluarkannya SK Ka.Kanwil BPN Prop. Sulut Tertangal 15 Januari 1996 No: 01/HGB/KWBPN/ 1996 oleh Tergugat I, sertipikat HGB No: 06/Desa Tongkeina, GS Khusus tanggal 11-12-1995 No: 22/1995 an. PT Sekawan Usaha Bhakti Nusa berkedudukan di Jakarta. Dimana tindakan-tindakan tersebut bertentangan dengan peraturan perundangundangan yang berlaku dan merupakan perbuatan sewenang-wenang atau penyalahgunaan wewenang sebab tanpa didasarkan fakta yang benar dan relevan serta tidak menerapkan ketentuan/azas-azas hukum yang berlaku, sehingga penggugat beralasan untuk menggugat sesuai dengan Pasal 53 ayat (1) dan (2) UU No. 5 Tahun 1986;

2. bahwa Penggugat secara resmi dan pasti menge-tahui mengenai diterbitkannya/ dikeluarkannya SK Ka.Kanwil BPN Prop. Sulut Tertangal 15 Januari 1996 No: 01/HGB/KWBPN/1996 oleh Tergugat I, sertipikat HGB No: 06/Desa Tongkeina, GS Khusus tanggal 11-12-1995 No: 22/1995 an. PT Sekawan Usaha Bhakti Nusa berkedudukan di Jakarta pada tanggal 11-7-1996 yaitu ketika Penggugat mempe roleh pemberitahuan secara lisan dari Penyidik di Kantor Polsek Kota Manado Utara menyangkut adanya foto copy produk Psl tersebut diatas yang telah dimasukkan oleh Ny. Poluan Lasut sehubungan laporan Polisi No.Pol: Lap/VII/96/Sekta.Mdo.Ut., tertanggal 10-7-1996, atas tindakan pengrusakan pagar;

3. bahwa Penggugat ada memiliki 2 (dua) bidang Tanah Milik Adat/Pasini, berdasarkan :

a. pembelian dari Usman Abdullah sesuai Akta Jual beli tertanggal 16-8-1994 No:42/AJB/VIII/1994 (P-2), dengan terlebih dahulu telah membayar $\mathrm{PH}$ jual beli TMA/Tongkeina, sesuai DI 306 BPN tertanggal 12-8-1994 (P-3) dan DI 305/ 1994 Nomor 4564;

b. pembelian dari Adnan sesuai Akta Jual beli tertanggal 16-8-1994 No:40/AJB/VIII/1994 (P4), dengan terlebih dahulu telah membayar $\mathrm{PH}$ jual beli TMA/Tongkeina, sesuai DI 306 BPN tertanggal 12-8-1994 (P-3) dan DI 305/ 1994 Nomor 4565.

4. bahwa menyangkut identitas dan pemilikan tanah-tanah dimaksud berdasarkan keterangan yang telah dikeluarkan oleh Tergugat II, masing-masing adalah: 
a. sesuai SKPT No: 406/Mdo/1994 tertanggal 11-8-1994 (P-6), yang menerangkan batasbatas yang bersebelahan dengan luas $37.220 \mathrm{M}^{2}$ (tiga puluh tujuh ribu dua ratus duapuluh meter persegi) an. Usman Abdullah;

b. sesuai SKPT No: 403/Mdo/1994 tertanggal 11-8-1994 (P-7), yang menerangkan batasbatas yang bersebelahan dengan luas $14.444 \mathrm{M}^{2}$ (empat belas ribu empat ratus empat puluh empat meter persegi) an. Adenan Asim.

5. bahwa berdasarkan adanya produk P-6 dan P-7 tersebut, dan ditambah dengan adanya Surat Keterangan Pemilikan Tanah tertanggal 25-7-1994 No:96/SKPT/DT/VII/1994 (P-8), Surat Keterangan Kesaksian tertanggal 20 -7-1994 (P-9), Surat Keterangan Pemilikan Tanah tertanggal 25-7-1994 No:97/SKPT/DT/VII/1994 (P-10), Surat Keterangan Kesaksian tertanggal 20 -7-1994 (P-11), maka penggugat mempunyai keyakinan terhadap identitas tanah-tanah a-quo dan kemudian telah melakukan pembelian di hadapan Camat Kepala Wilayah Kecamatan Molas, sesuai ketentuan perundang-undangan yang berlaku;

6. bahwa pada sekitar tahun 1994, seorang bernama Arifin Lihu yang mengaku sebagai pegawai dari Tergugat I telah menemui Penggugat menanyakan menyangkut tanah-tanah dimaksud, guna mengadakan pengukuran dan inventarisasi terhadap tanah-tanah di Desa Tongkeina, Kec. Molas Kota Manado, sehubungan dengan adanya permohonan dari PT. Pola Pelita Ekspress (an. Ny. Poluan Lasut), dan Penggugat telah menyerahkan surat-surat/datadata kepemilikan Penggugat kepada Arifin Lihu.

7. bahwa dengan diserahkannya semua data-data menyangkut kepemilikan Penggugat atas tanah-tanah a-quo kepada Tergugat I, dan telah pula diadakan pengukuran dan inventarisasi, maka pada hakekatnya Tergugat I telah mengetahui dengan sebenar-benarnya mengenai hak kepemilikan Penggugat terhadap tanah-tanah a-quo

8. bahwa hingga sekarang Penggugat tidak pernah merasa ada pengalihan kedua bidang tanah tersebut kepada pihak manapun dan dengan cara apapun, bahkan kedua bidang tanah tersebut sepenuhnya berada dalam penguasaan Penggugat.

9. bahwa walaupun Tergugat I telah mengetahui mengenai hak kepemilikan dan penguasaan $t$ anah Penggugat, bahkan Tergugat II pernah mengeluarkan Produk P-6 dan P-7, ternyata Tergugat I tetap menerbitkan/mengeluarkan SK Ka. Kanwil BPN Nomor 01/HGB/KWBPN/1996 yang ada menyatakan bahwa tanah tersebut adalah Tanah Negara dan kemudian memberikan hak baru dengan HGB seluas $159.065 \mathrm{M}^{2}$ (seratus lima puluh sembilan ribu enam puluh lima meter persegi) termasuk juga tanah-tanah Penggugat kepada PT. Sekawan Usaha Bhakti Nusa berkedudukan di Jakarta, dan apa dasarnya Tergugat I menyatakan tanah-tanah Penggugat sebagai tanah bekas Eigendom Verponding Nomor 257 Seb. Karena lokasi tersebut merupakan bekas wilayah Kabupaten Minahasa yang menjadi Kota Manado pada tahun 1988, apakah mungkin terdapat tanah Eigendom Verponding di luar wilayah Kota Manado;

10.bahwa perbuatan Tergugat I menerbitkan/mengeluarkan SK Ka. Kanwil BPN Nomor 01/HGB/KWBPN/1996, adalah tidak mempertimbangkan kepentingan pihak Penggugat yang terkait dan terkena langsung dengan Surat Keputusan a-quo behkan kepentingan Penggugat sama sekali tidak terwakili dan tidak diperhartikan, sebab Tergugat I hany amendengar 
keterangan satu pihak saja yaitu Ny. Poluan Lasut, dan mengenyampingkan bukti-bukti yang usdah dikemukakan oleh Penggugat, sehingga perbuatan Tergugat I tersebut merupakan perbuatan yang bertentangan dengan azas-azas umum Pemerintah an yang baik, dengan demikian Surat Keputusan SK Ka. Kanwil BPN Nomor 01/HGB/KWBPN/1996 adalah cacat hukum dan oleh karenanya adalah BATAL DEMI HUKUM atau TIDAK SAH beserta segala akibat hukumnya;

11.bahwa demikian pula halnya denga nperbuatan Tergugat II menerbitkan/mengeluarkan Sertipikat HGB Nomor 06/Desa Tongkeina, GS Khusus tertanggal 11-12-1995 nomor:22/1995 (P-1), adalah bertentangan dengan peraturan perundang-undangan yang berlaku, sebab selain selain telah didasarkan pada suatu Surat Keputusan yang cacat hukum, lagi pula tidak berdasarkan fakta yang benar dan relevan, dan oleh karenanya adalah BATAL DEMI HUKUM atau TIDAK SAH beserta segala akibat hukumnya;.

\section{Putusan Peradilan Tata Usaha Negara}

Tingkat Pertama

Pertimbangan Hukum

1. Menimbang oleh karena pasal 53 Undang-Undang Nomor 5 Tahun 1986, tidak memberikan kejelasan tentang apa yang dimaksud dengan kepentingan, maka peradilan berpedoman pada dokrin dalam bidang hukum tata usaha negara yang menyatakan bahwa penegrtian kepentingan dalam kaitannya dengan hukum acara tata usaha negara mengandung 2 (dua) arti yaitu nilai yang harus dilindungi oleh hukum dan kepentingan berproses di pengadilan.

2. menimbang, bahwa berdasarkan bukti-bukti yang diajukan Penggugat berupa Akta Jual Beli atas tanah, dan surat Keterangan Pendaftaran Tanah serta berdasarkan hasil pemeriksaan setempat oleh pengadilan di lokasi tanah obyek HGB yang dipersengketakan adalah tanah yang diperoleh Penggugat berdasarkan Akta Jual Beli dalam bukti P-2 dan P-4 tersebut, sehingga berdasarkan fakta adanya tanah yang tumpang tindih tersebut menjadi alasan begi Penggugat untuk mempertahankan kepentingannya dengan cara mengajukan gugatan ini ke Pengadilan.

3. meninmbang bahwa untuk menguji keputusan Tergugat I dan Tergugat II apakah dapat dinyatakan batal atau tidak sah, maka Pengadilan akan meng-gunakan tolok ukur sebagai pengujian yaitu pasal 53 ayat (2) a, b, c Undang-Undang Nomor 5 Tahun 1986 bahwa surat keputusan dapat dinyatakan batal atau tidak sah apabila keputusan tersebut dikeluarkan:

a.bertentangan dengan pera-turan perundang-undangan

b.melampaui batas kewe-nangan

c.dengan sewenang-wenang

4. Berdasarkan pemeriksaan oleh Pengadilan di lokasi tanah tersebut, diperoleh fakta bahwa benar tanah hak Penggugat berdasarkan Jual Beli di hadapan PPAT adalah tumpang tindih dengan tanah obyek keputusan in-litis.

5. Menimbang bahwa dengan adanya fakta bahwa Tergugat tidak cukup mempertimbangkan fakta-fakta yang relevan serta tidak mempertimbangkan ke-pentingan Penggugat dalam mengambil keputusannya, maka Pengadilan berkesim-pulan bahwa Tergugat telah 
mengeluarkan keputusan sewe-nang-wenang oleh karena itu keputusan Tergugat I in-litis harus dinyatakan batal.

6. Menimbang bahwa oleh karena keputusan Terguga I dan Tergugat II yang dimohon pleh Penggugat Intervensi untuk tetap dipertahankan ternyata oleh Pengadilan telah di-nyatakan batal, maka tuntutan Penggugat Intervensi yang memohon agar menolak Peng-gugat (Gun Honandar) harus-lah dinyatakan tidak beralasan dan ditolak, dengan per-timbangan

7. Karena Keputusan Tergugat I dan Tergugat II yang dimohon oleh Penggugat Intervensi untuk tetap dipertahankan ternyata oleh Pengadilan telah dinyatakan batal sebagaimana dipertimbangkan dalam pokok perkara guna mempertahankan hak dan kepentingannya selaku pemilik/pemegang Surat Kepu-tusan Ka.Kanwil BPN Prop. Sulut Tertangal 15 Januari 1996 No: 01/HGB/KWBPN/ 1996 dan sertipikat HGB No: 06/Desa Tongkeina, GS Khusus tanggal 11-12-1995 No: 22/1995 an. PT Sekawan Usaha Bhakti Nusa berkedudukan di Jakarta.

\section{Putusan}

Dalam eksepsi : Menyatakan eksepsi Tergugat I dan II ditolak seluruhnya.

Dalam Pokok Perkara : Mengabulkan gugatan Penggugat seluruhnya dan menyatakan batal keputusan Tergugat I tentang Surat Keputusan Pemberin Hak Guna bangunan dengan Surat Keputusan Nomor: 01/ HGB/KWBPN/1996 tanggal 15-01-1995 dan keputusan Tergugat II tentang Sertipikat HGB No: 06/Desa Tongkeina, GS Khusus tanggal 11-12-1995 No: 22/1995 an. PT Sekawan Usaha Bhakti Nusa berkedudukan di Jakarta.

\section{Tingkat Banding}

Pertimbangan Hukum

a. menimbang karena yang menjadi obyek sengketa perkara menyangkut surat keputusan yang di terbitkan tergugat I dan Tergugat II/Pembanding I dan Pembanding II, penggugat/terbanding wajib membuktikan dalil-dalil, gugatannya yaitu apakah benar para tergugat/pembanding telah melakukan pelanggaran kedua surat keputusan in litis, oleh karena kesalahan dalam prosedur merupakan tindakan yang bertentangan dengan pertentangan yang berlaku atau bertentangan dengan azas- azas umum pemerintahan yang baik

b.menimbang bahwa para tergu-gat / pembanding menolak dalil - dalil penggugat / terbanding untuk menyatakan bahwa tanah yang tercantum dalam kedua akte jb tersebut adalah merupakan tanah negara eyeigerdom verponding no . 275 / Tongkeina yang bukan tanah adat pasini , hal ini dibuktikan para tergugat / pembanding dengan menge-mukakan catatan catatan yang ada di kantor BPN Manado bahwa tanah sengketa aquo adalah tanah negara sejak tgl 24 Januari 1958 .

\section{Putusan}

menimbang bahwa dari bukti - bukti yang ada dipersidangan terbukti tanah sengketa a quoberasal dari tanah exeigendom verponding no .275 / Tongkeina dan sebagian lagi berasal dari tanah LR, hal mana sesuai catatan mengenai tanah yang ada di Kantor BPN 


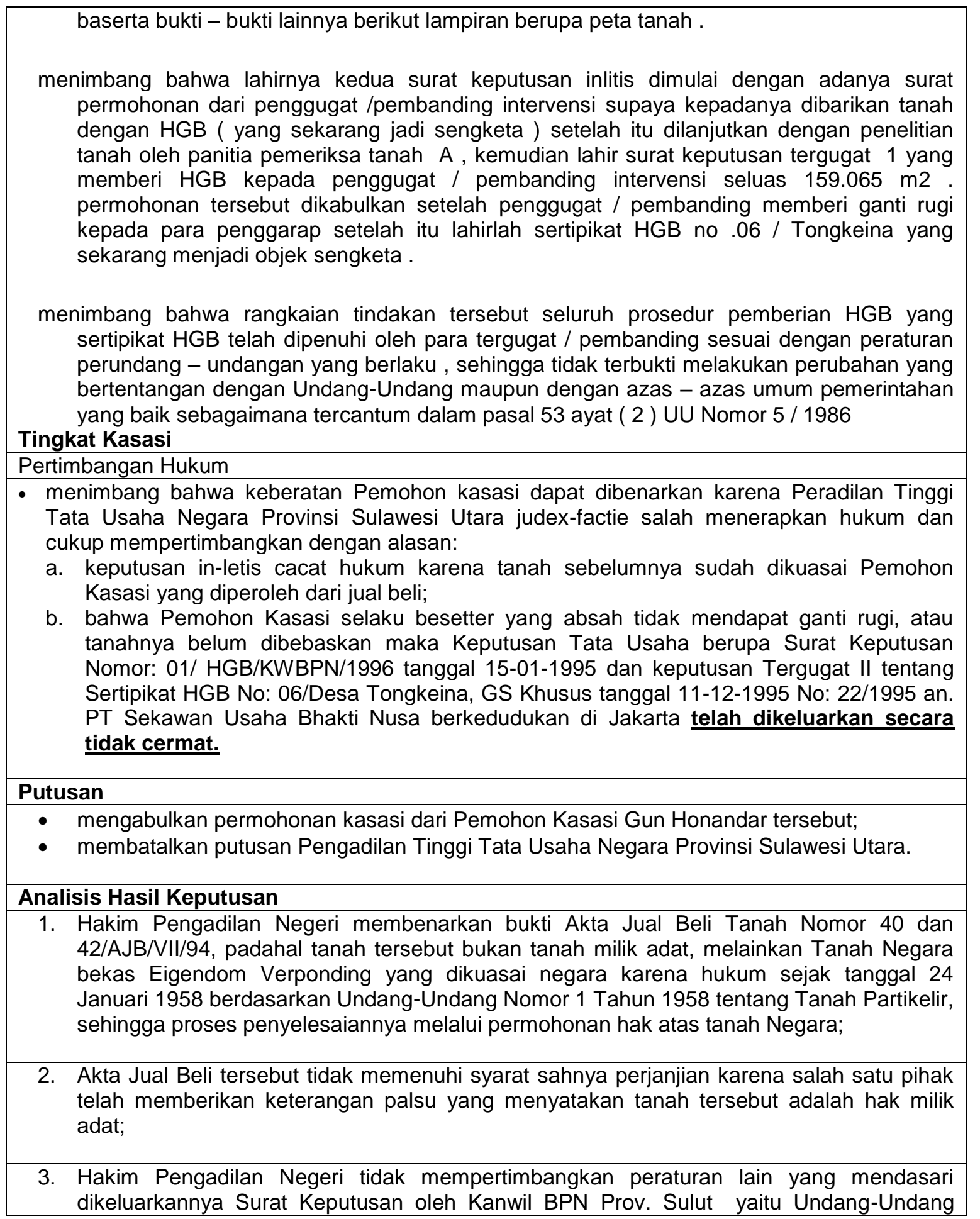




\begin{tabular}{|c|c|}
\hline & $\begin{array}{l}\text { Nomor } 1 \text { Tahun } 1958 \text { tentang Tanah Partikelir, dan hanya mendasarkan pada Undang- } \\
\text { Undang Nomor } 5 \text { Tahun 1986, bahwa keputusan yang dibuat oleh Kanwil BPN Prov. Sulut } \\
\text { dan Kantor Pertanahan Kota Manado adalh sewenang-wenang, seharusnya peraturan } \\
\text { yang menjadi landasan kerja BPN turut dijadikan bahan pertimbangan. }\end{array}$ \\
\hline 4. & $\begin{array}{l}\text { Hakim Tingkat Banding sudah dapat mempertimbangkan catatan administrasi BPN bahwa } \\
\text { tanah yang dijadikan objek sengketa (a-quo) adalah tanah negara sejak tanggal } 24 \\
\text { Januari 1958, berdasarkan Undnag-Undang Nomor } 1 \text { Tahun } 1958 \text { tentang Tanah } \\
\text { Partikelir. }\end{array}$ \\
\hline 5. & $\begin{array}{l}\text { Keputusan Hakim Agung dengan pertimbangan karena tanah sebelumnya sudah dikuasai } \\
\text { Pemohon Kasasi yang diperoleh dari jual beli, tidak mempertimbangkan pula dasar } \\
\text { dikeluarkannya SK Kakanwil BPN Prov. Sulut berdarsarkan Undang-Undang Nomor } 1 \\
\text { tahun 1958, yaitu tanah negara yang berasal dari tanah partikelir tidak dapat diperjual } \\
\text { belikan dan dialihkan oleh Pejabat Pembuat Akta Tanah; }\end{array}$ \\
\hline 6. & $\begin{array}{l}\text { Keputusan tentang telah mengeluarkan Surat Keputusan Nomor: 01/ HGB/KWBPN/1996 } \\
\text { tanggal 15-01-1995 dan keputusan Tergugat II tentang Sertipikat HGB No: 06/Desa } \\
\text { Tongkeina, GS Khusus tanggal 11-12-1995 No: } 22 / 1995 \text { an. PT Sekawan Usaha Bhakti } \\
\text { Nusa berkedudukan di Jakartakepada secara tidak cermat, tidak pula } \\
\text { mempertimbangakan dasar dikeluarkannya keputusdan tata usaha negara tersebut, yaitu } \\
\text { Undang-Undang Nomor } 1 \text { tahun 1958, tentang Tanah Negara bekas Eigendom } \\
\text { Verponding. Hal ini sangat merugikan PT Sekawan Usaha Bhakti Nusa berkedudukan di } \\
\text { Jakarta yang beritikad baik mengajukan permohonan hak atas tanah negara. }\end{array}$ \\
\hline 7. & $\begin{array}{l}\text { Untuk menghindari tumpang tindih putusan terhadap obyek sengketa yang sama (obyek } \\
\text { ini juga terdaftar di Pengadilan Negeri Manado antara PT Sekawan Usaha Bhakti sebagai } \\
\text { penggugat melawan Gun Honandar sebagai tergugat), dengan satu obyek sengketa yang } \\
\text { di perkarakan pada Badan Peradilan yang berbeda, seyogyanya berdasarkan aturan } \\
\text { peralihan Undang -Undang Nomor } 5 \text { Tahun 1986, seharusnya salah satu dari kedua } \\
\text { Badan Peradilan tersebut merelakan untuk di periksa dan diputus oleh badan peradilan } \\
\text { yang lebih kompeten. }\end{array}$ \\
\hline
\end{tabular}

\begin{tabular}{|l|l|}
\hline Nomor Urut & 6 \\
\hline $\begin{array}{l}\text { Lokasi } \\
\text { Kasus }\end{array}$ & Kota Banjarmasin \\
\hline $\begin{array}{l}\text { Pihak yang } \\
\text { bersengketa }\end{array}$ & $\begin{array}{l}\text { Penggugat = Gusti Aakhmad Zakariani } \\
\text { Tergugat I = Ahli Waris dari Gusti Adam } \\
\text { Tergugat II = Dr. Taufan Iskandar Wong Jaya } \\
\text { Turut Tergugat = Kantor Pertanahan }\end{array}$ \\
\hline
\end{tabular}




\begin{tabular}{|l|l|}
\hline $\begin{array}{l}\text { Jenis } \\
\text { Sengketa }\end{array}$ & kepemilikan \\
\hline \multicolumn{2}{|l|}{ Duduk Perkara } \\
\hline
\end{tabular}

1. penggugat mempunyai sebidang tanah perwatasan di Jl. Perintis Kemerdekaan RT 22 Kota Banjarmasin sesuai jual beli tanggal 2 Juli 1929, surat jual beli ada pada penggugat.

2. riwayat tanah tersebut berasal dari jual beli antara Pangeran Abdul Madjid Kasoema dan Gusti Adam, dan oleh Gusti Adam dijual kembali kepada Gusti Hanafiah

3. tanah tersebut oleh ahli waris Gusti Hanafiah dihibahkan kepada penggugat untuk hal mana dibuat surat hibah di bawah tangan dan surat jual beli asal tanggal 2 juli 1929 diserahkan pula kepada penggugat.

4. tanpa sepengetahuan penggugat, tanah tersebut oleh ahli waris Gusti Adam dimohonkan sertipikat kepada turut tergugat, dan keluar sertipikat Hak Milik Nomor 1202. dengan dasar adanya sertipikat tersebut, tergugat I telah menjual tanah tersebut kepada tergugat II

dalam eksepsi :

- bahwa dalil penggugat tidak benar, maka gugatan penggugat dinyatakan untuk ditolak dan atau setidak-tidaknya tidak dapat diterima dalam pokok perkara

- bahwa surat jual beli yang ada pada penggugat merupakan jual beli antara Pangeran Abdul Madjid

dalam pokok perkara :

- Kasoema (penjual) dengan Gusti Adam (pembeli) dan bukan antara Gusti Adam dengan Gusti Hanafiah (kakek penggugat),bahwa para ahli waris Gusti Hanafiah menyatakan tidak pernah menghibahkan tanah obyek sengketa kepada penggugat.

\section{A. Peradilan Umum}

2.A.1 Tingkat Pertama

Pertimbangan Hukum

- eksepsi yang diajukan tergugat I dan turut tergugat sudah memasuki materi pokok perkara dan bukan eksepsi tentang kewenangan mengadili sehingga eksepsi itu harus ditolak.

- bahwa surat bukti yang diajukan oleh penggugat sesuai dengan aslinya, dan telah dibubuhi materai secukupnya maka surat bukti itu dinyatakan sah dan berharga

- menimbang terhadap bukti yang diajukan penggugat

- P1 adalah jualbeli tanah sengketa antara P. Abdul Majid dan Gusti Adam 


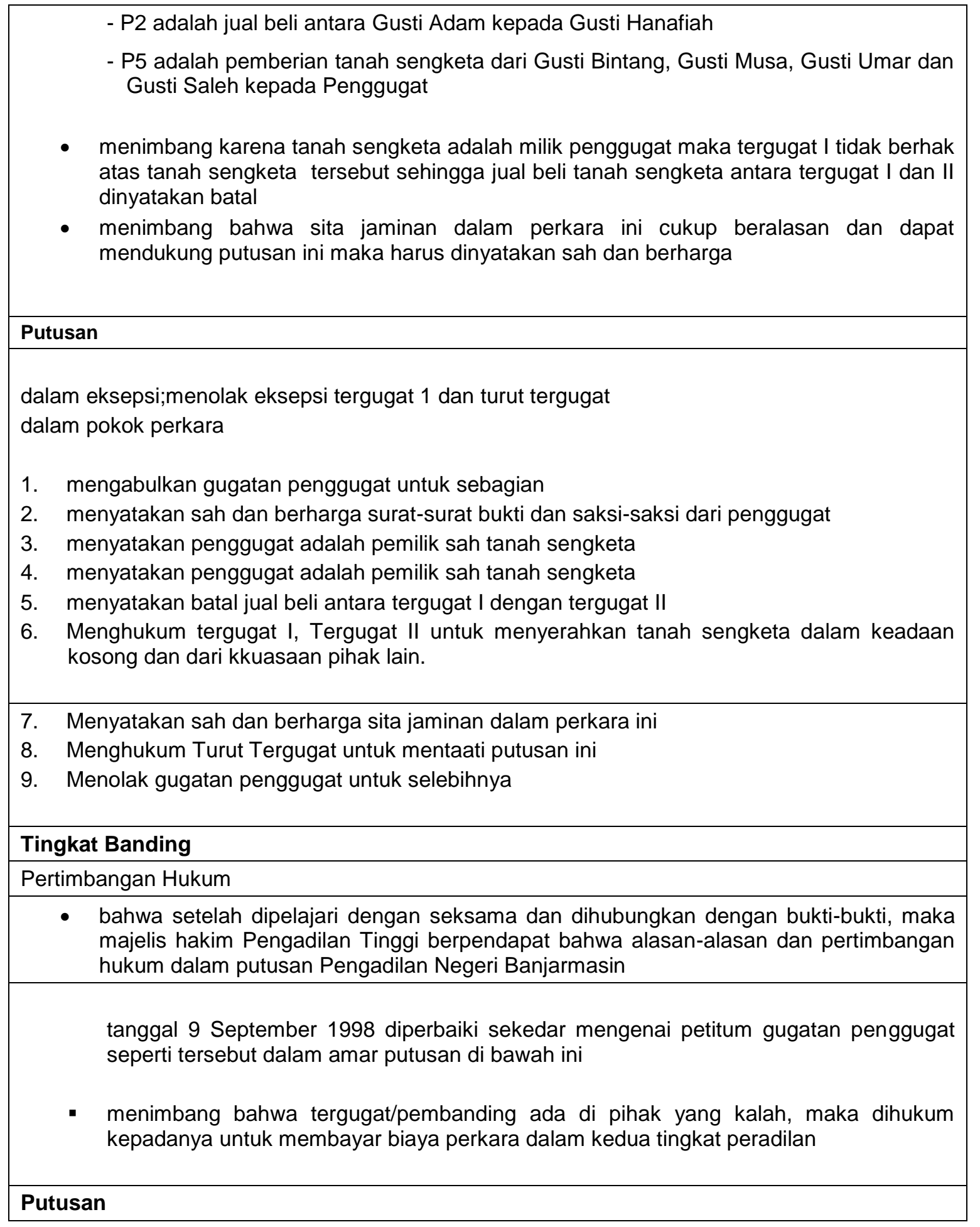


dalam eksepsi:

- menolak eksepsi tergugat I dan II

dalam pokok perkara :

1. mengabulkan gugatn penggugat untuk sebagian

2. menyatakan penggugat adalah pemilik sah tanah sengketa

3. menyatakan batal jual beli antara tergugat I dengan tergugat II

4. Menghukum tergugat I, Tergugat II untuk menyerahkan tanah sengketa dalam keadaan kosong dan dari kkuasaan pihak lain.

5. Menyatakan sah dan berharga sita jaminan dalam perkara ini

6. Menghukum Turut Tergugat untuk mentaati putusan ini

7. Menolak gugatan penggugat untuk selebihnya

\section{Tingkat Kasasi}

Pertimbangan Hukum

- menimbang, atas keberatan pemohon kasasi, MA berpendapat keberatan itu tidak dapat dibenarkan karena judex factie tidak salah menerapkan hukum, mengenai penilaian hasil pembuktian yang bersifat penghargaan tentang suatu kenyataan, tidak dapat dipertimbangkan karena pemeriksaan dalam tingkat kasasi hanya berkenan dengan adanya kesalahan penerapan hukum, adanya peklanggaran hukum,kelalaian dalam memenuhi syarat-syarat yang diwajibkan oleh perundang-undangan atau Pengadilan tidak berwenang atau melampaui batas kewenangannya.

- menimbang bahwa putusan judex factie dalam perkara tidak bertentangan dengan hukum

\section{Putusan}

-mengadili:

menolak permohonan kasasi dari :

-Gusti Nurhasanah cs

Peninjauan Kembali

Pertimbangan Hukum 
- menimbang, bahwa pemohon PK telah mengajukan alasan PK yang pada pokoknya adalah :

1. hakim mengabaikan mengenai kaburnya obyek sengketa

2. hakim melanggar prinsip contradictoir

3. hakim keliru menilai alat bukti surat P2 dan P5 yang dijadikan dasar putusannya memenangkan Termohon

- PK/Penggugat, P2 ternyata mengandung kepalsuan sesuai hasil Lab. kriminal dan P5 berupa hibah dibawah tangan tidak memenuhi syarat PP No. 10 tahun 1961

- menimbang, mengenai keberatan ad.3, bahwa keberatan tersebut dapa dibenarkan karena terdapat kekhilafan yang nyata dari putusan MA RI tanggal 26 oktober 2001 karena MA RI tidak mempertimbangkan bukti P2 dan P5 sedangkan P5 yang merupakan akta hibah hanya dimuat di bawah tangan dan tidak memenuhi syarat PP No. 10 tahun 1961.

\section{Putusan}

mengadili

- mengabulkan permohonan peninjauan kembali Dr. Taufan Iskandar Wongjaya

- membatalkan putusan MA RI tanggal 26 Oktober 2001

Analisa kasus :

- $\quad$ Ketentuan dalam pasal 11 ayat 2 huruf b UU No. 4 tahun 2004 tentang Kekuasaan Kehakiman mengatur tentang hak uji Mahkamah Agung terhadap peraturan perundangundangan yang lebih rendah dari undang-undang, hak uji tersebut dapat dilakukan baik terhadap materi muatan ayat, pasal dan atau bagian dari peraturan perundang-undangan tersebut yang bertentangan dengan peraturan perundang-undangan yan lebih tinggi maupun terhadap pembentukan peraturan perundang-undangan tersebut. Selain UU No. 5 tahun 1986 (PTUN) pertimbangan hukum dalam putusan Hakim PTUN hanya memperhatikan PP No. 10 tahun 1961 jo Adanya perbedaan penafsiran mengenai Dari kasus di atas menggambarkan ketidak telitian/kurang cermatnya hakim dalam memeriksa bukti perkara

- $\quad$ Dalam memeriksa perkara hakim tidak memperhatikan hukum adat, yaitu jual beli yang dilakukan bersifat tunai dan terang dan PP No. 24 tahun 1997 tentang Pendaftaran Tanah 
- $\quad$ Bukti yang diajukan pada tingkat kasasi sama dengan pada waktu diajukan Peninjauan Kembali, tidak ada novum (bukti baru)

- $\quad$ Adanya perbedaan penafsiran mengenai alat bukti yang sama pada tingkat kasasi dan peninjauan kembali

\begin{tabular}{|l|l|}
\hline Nomor Urut & $\mathbf{7}$ \\
\hline Lokasi Kasus & Kota Pontianak \\
\hline $\begin{array}{l}\text { Pihak yang } \\
\text { bersengketa }\end{array}$ & $\begin{array}{l}\text { Penggugat }=\text { Dahlan Iskan } \\
\text { Tergugat }=\text { Kakanwil BPN Kalimantan Barat }\end{array}$ \\
\hline Jenis Sengketa & Tumpang Tindih Kepemilikan \\
\hline Duduk Perkara
\end{tabular}


1. bahwa penggugat dengan surat gugatannya tertanggal 29 Mei 2002 yang ditanda tangani oleh kuasa hukumnya telah didaftarkan di Kepaniteraan Pengadilan TUN Pontianak pada tanggal 3 Juni 2002 di bawah register nomor: 18 G PTUN-PTK 2002.

2. bahwa tergugat telah menerbitkan Surat Keputusan Nomor : 01 tahun 2002 tertanggal 29 Januari 2002, tentang Pembatalan sertipikat Tanah Hak Milik No. :5938/Desa Sungai raya atas nama H.Ali Lakana seluas $16.019 \mathrm{~m} 2$ terletak di Kelurahan Raya Kecamatan Sungai Raya Kota Pontianak Provinsi Kalimantan Barat.

3. bahwa tergugat pada tanggal 18 April 2002, dengan surat No ; 570-141-41-2002 perihal pembatalan Judul SK No 01 tahun 2002 tentang Pembatalan Sertipikat Tanah Hak Milik Nomor :5938/Desa Sungai Raya atas nama H. Ali Lakana seluas $16.106 \mathrm{~m} 2$ terletak di Kelurahan Sungai Raya Kecamatan Sungai raya Kabupaten Pontianak Provinsi Kalimantan Barat.

4. bahwa Surat Keputusan tergugat No : 01 tahun 2002 tanggal 29 Januari 2002 tersebut diketahui penggugat pada tanggal 23 Mei 2002, yaitu pada saat menerima Surat dari Kepala Kantor Pertanahan kabupaten Pontianak No.520-39-11.2-2002, tertanggal 21 Mei 2002 perihal pelaksanaan SK Pembatalan No. 01 tahun 2002 tanggal 29 januari 2002.

5. bahwa sertipikat Hak Milik No. 5938 tanggal 3 Nopember 1992 Desa Sungai Raya GS Nomor :8672/1992 tanggal 7 September 1992,dengan luas 16.109m2 atas nama H. Ali Lakana.

6. Bahwa menurut penilaian penggugat penerbitan Surat Keputusan Nomor 01 tahun 2002 tanggal 29 Januari 2002 tentang Pembatalan Sertipikat Hak Milik Nomor 5938/Desa Sungai Raya kabupaten Pontianak Propinsi kalimantan Barat adalah bertentangan dengan peraturan perundang-undangan yang bersifat procedural atau formal dan bertentangan dengan asas kepatutan karenanya merupakan perbuatan melawan hukum dengan alasanalasan sebagai berikut ; 
7. bahwa Surat Keputusan tergugat Nomor : 01 tahun 2002, tanggal 29 Januari 2002 adalah cacat hukum, karena tidak menyebutkan secara terperinci gambar Situasi, pemilik sertipikat letak tanah, ukuran, batas-batas dari tanah dengan Sertipikat Hak Milik No. 5938/Desa Sungai Raya Gambar Situasi No. 8672/1992 tanggal 7 September 1992, dahulu atas nama $\mathrm{H}$. ALI LAKANA sekarang atas nama DAHLAN ISKAN berdasarkan akta jual beli No. 536/SR/PPAT-Kec. Sei Raya, tanggal 28 Mei 1993 yang terletak di jalan Ahmad Yani II Desa Sungai Raya kalimantan Barat, dengan ukuran lebar bagian depan 89 meter, lebar bagian belakang 59 meter dan panjang 214 meter, luasnya kurang lebih $16.109 \mathrm{~m} 2$.

8. bahwa putusan Pengadilan Negeri Pontianak No. 248/Pid.B/1994/PN>PTK yang menyatakan terdakwa SY. JULIANTONI Bin SY. AHMADINI telah terbukti secara sah dan meyakinkan bersalah melakukan tindak pidana penggelapan dan pemalsuan. Putusan tersebut adalah mengenai tindak pidana menggelapkan sebagian uang hasil penjualan tanah sertipikat Hak Milik No. 5938/Desa Sei raya dengan Gambar Situasi 8672/1992 tanggal 7 September 1992 yang seharusnya diterima tanpa sepengetahuan penggugat, tanah tersebut oleh ahli waris Gusti Adam dimohonkan sertipikat kepada turut tergugat, dan keluar sertipikat Hak Milik Nomor 1202. Seharusnya diterima H. ALI LAKANA yaitu dengan cara membuat surat pernyataan seolah-olah uang hasil penjualan sudah diterima H.ALI LAKANA.

9. bahwa dengan diterbitkannya Surat Keputusan No. 01 tahun 2002 tanggal 29 Januari 2002 tentang pembatalan Sertipikat Hak Milik No. 5938/Desa Sungai Raya atas nama H>ALI LAKANA seluas 16.109 m2 terletak di kelurahan Sei Raya Kecamatan Sei Raya Kabupaten Pontianak Propinsi Kalimantan Barat adalah merugikan penggugat sebagai pembeli yang beritikad baik berdasarkan Akte Jual Beli No. 536/SR/PPAT KEC SEI RAYA/1993 tanggal 28 Mei 1993.

\section{Peradilan TUN}

Tingkat Pertama

Pertimbangan Hukum 
Terhadap Eksepsi Tergugat

- bahwa tergugat menolak gugatan penggugat dengan alasan bahwa Pengadilan TUN tidak berwenang mengadili perkara ini sebagaimana dimaksud dalam pasal 77 Undangundang No. 5 tahun 1986 dan Surat Edaran Mahkamah Agung Republik Indonesia No. MA/ Kumdil/ 031/ i/ K/ 1991 TANGGAL 22 JANUARI 1991, karena tergugat beritikad baik melaksanakan putusan Mahkamah Agung Republik Indonesia atas putusan No. 86/K/AG/1989 tertanggal 28 Agustus 1990 yang telah mempunyai kekuatan hukum tetap (vide BUKTI T-3a);

- putusan mana diperjelas dengan Surat Mahkamah Agung Republik Indonesia No. 10/TUADA-AG/XI/2001, tanggal 27 Nopember 2001 (vide BUKTI T-3). Sedangkan lokasi tanah yang ditunjuk adalah sebagaimana putusan Pengadilan Negeri Pontianak No. 19/1980/Perdata tanggal 18 Maret 1982 (vide BUKTI T-7) jo Putusan Pengadilan Tinggi Pontianak No. 17/PDT/PT/1982 tanggal 19 Agustus 1982 (vide BUKTI T-6).

\section{Tingkat Banding}

Pertimbangan Hukum

Alasan Keberatan

1. menimbang, bahwa penggugat/pembanding telah mengajukan permohonan pemeriksaan banding tanggal 10 September 2002, diajukan dalam tenggang waktu dan dengan cara yang ditentukan oleh UndangUndang maka pemeriksaan banding tersebut dapat dinyatakan diterima.

2. menimbang bahwa memori banding dari Penggugat/Pemban-ding diajukan tanggal 25 September 2002

\section{Putusan}

- mengabulkan gugatn penggugat untuk sebagian

- menyatakan penggugat adalah pemilik sah tanah sengketa

\section{Tingkat Kasasi (dalam proses)}

\section{Analisa Kasus}

- Kasus ini sudah inkracht di Peradilan Umum dan tergugat (BPN) membatalkan sertipikat berdasarkan putusan Mahkamah Agung RI tanggal 20 Agustus 1990 yang telah mempunyai kekuatan hukum tetap. 
- Hakim PTUN membuat putusan yang sejalan dengan hasil putusan dari Peradilan Umum (Perdata) yang sudah mempunyai kekuatan hukum tetap

- Hakim PT TUN dalam pertimbangan hukumnya mencantumkan pasal 32 (2) PP No. 24 tahun 1997 bahwa jika sudah 5 tahun ada keberatan dari pihak lain, harus mengajukan gugatan tersebut ke PN mengenai penguasaan tanah atau ke PTUN jika mengenai penerbitan sertipikat, HakimPT TUN membatalkan putusan PTUN dan menyatakan batal Surat Keputusan Tergugat (BPN) tentang pembatalan Sertipikat Hak Milik.

- Adanya perbedaan putusan antara Peradilan Umum dan PTUN mengakibatkan suatu sertipikat dibatalkan lebih dari sekali

\section{Analisis Keputusan Hakim}

Pada hakikatnya hukum diciptakan untuk mewujudkan adanya kepastian dan keadilan. Dalam hal ini prinsip untuk mewujudkan kepastian yang diterapkan melalui mekanisme hukum seringkali tidak sejalan dengan prinsip keadilan. Jika hal ini terjadi pada sistem peradilan pertanahan dewasa ini, maka efektifitas sistem hukum tersebut perlu dikaji dari berbagai sudut pandang sebagaimana yang akan diutarakan berikut ini.

\section{a. Sudut Pandang Peradilan Administrasi Publik}

Salah satu masalah yang cukup mengkhawatirkan dewasa ini adalah adanya sudut pandang yang berbeda dalam penafsiran suatu perkara pertanahan. Dalam hal ini terdapat perbedaan norma pada PP 24 Tahun 1997 dengan Pasal 55 UU No 5 Tahun 1986. Menurut PP 24 Tahun 1997, kegiatan pendaftaran hak atas tanah adalah kewajiban pemerintah yang secara operasional dilakukan oleh Kepala Kantor Pertanahan (beserta paraa pejabat dan stafnya) dibantu pejabat lain untuk melaksanakan kegiatan tersebut (PPAT, PPAT Sementara, Pejabat Lelang, Panitia Adjudikasi). Maka Kepala Kantor Pertanahan beserta para pejabat tersebut yang terlibat dalam kewenangan melaksanakan kegiatan yang menghasilkan produk sertipikat hak atas tanah adalah tergolong Pejabat Tata Usaha Negara.

Oleh karena itu Kepala Kantor Pertanahan Kabupaten dan Kota sebagai Pejabat TUN mempunyai kewenangan mengeluarkan Keputusan TUN yang dikenal dengan istilah beschiking. Maka pihak yang merasa dirugikan akibat putusan pejabat tersebut dapat meminta keadilan melalui peradilan TUN. Jadi Keputusan Pejabat TUN merupakan dasar lahirnya sengketa Tata Usaha Negara. Keputusan Peradilan TUN dapat menyatakan batal atau tidak sahnya dengan atau disertai tuntutan ganti rugi dan atau rehabilitasi.

Permasalahan yang timbul dalam sengketa menyangkut dua hal. Pertama masalah tenggang waktu kedua delik sengketa. Pasal 5 UU No 1986 tentang TUN menyatakan tenggang waktu gugatan atas Keputusan TUN selama 90 hari sejak diterimanya atau diumumkan keputusan tersebut. Pengertian diterima oleh tergugat ini dalam prakteknya menjadi bervariasi. Sementara itu PP No.24 Tahun 1997 menyatakan bahwa produk sertipikat yang diterbitkan atas dasar itikad baik, jika dalam waktu lima tahun berturut-turut tidak ada yang menggugat, tidak dapat lagi dilakukan tuntutan hukum ke peradilan. 
Permasalahan kedua menyangkut, sudut pandang rasa kepuasan dan keadilan. Jika salah satu pihak merasa tidak puas dan merasa diperlakukan tidak adil, maka dapat melakukan upaya hukum lain dengan delik perdata bahkan dapat menyangkut delik pidana. Delik ini seharusnya dilakukan setelah upaya peradilan TUN. Dalam kenyataan delik perdata sering dilakukan sehingga para pejabat TUN Kantor Pertanahan langsung disidik oleh aparat kepolisian atau kejaksaan.

\section{b. Sudut Pandang Sosiologi Hukum Kepastian Hak Atas Tanah}

Berbagai konflik penguasaan tersebut mengindikasi adanya ketidakpastian hubungan penguasaan manusia dengan tanah, sedangkan kepastian adalah merupakan hal yang mendasar untuk mengembangkan kehidupan dan penghidupannya. Oleh karena itu salah satu kepastian yang hakiki adalah kepastian hukum penguasaan atas tanah. Kepastian hukum akan terpenuhi apabila tidak ada lagi keraguan dan kekhawatiran mengenai kepemilikan tanahnya, baik merupakan keyakinan dari dirinya sendiri maupun atas pengakuan pihak lain.

Beberapa fakta menunjukkan, bahwa keadaan yang berkembang di masyarakat, kepastian hak milik atas tanah, meskipun telah didaftarkan ternyata masih bisa dipermasalahkan, bahkan sampai menjadi sengketa di Lembaga Pengadilan. Keadaan itu menimbulkan keraguan dan kekhawatiran, dimana sumber ketidak pastian tersebut terutama menyangkut batas, letak tepat dan bukti kepemilikan. Dengan adanya ketidakpastian itu, maka tujuan kepastian hukum hak milik atas tanah belum terwujud.

Dalam hubungan dengan kepastian hukum, seorang pakar hukum, Achmad Ali (1999) berpendapat bahwa tujuan hukum dapat dikaji melalui tiga sudut pandang, yaitu dari sudut pandang ilmu hukum positif-normatif atau yuridis-dogmatis, dimana tujuan dititik beratkan pada kepastian hukumnya, dari sudut pandang filsafat hukum dititik beratkan pada segi keadilan dan dari sudut pandang sosiologi hukum tujuan dititik beratkan pada segi kemanfaatannya. Sementara itu, sistem pendaftaran tanah yang berlaku menetapkan bahwa sistem publikasinya adalah sistem negatif, tetapi yang mengandung unsur positif, karena akan menghasilkan surat-surat tanda bukti hak yang berlaku sebagai alat pembuktian yang kuat seperti tercantum dalam Peraturan Pemerintah No. 24 Tahun 1997 tentang Pendaftaran Tanah. Dengan demikian sistem pendaftaran tanah itu tidak sepenuhnya memenuhi tujuan hukum positif-normatif, sehingga kepastian yang diperoleh masih mengandung kelemahan. Kelemahan itu menunjukkan, bahwa sistem pendaftaran tanah pada saat ini belum memberikan kepastian hukum hak milik atas tanah secara efektif.

Efektifitas hukum menurut Lawrence M. Friedman (1989), akan terwujud apabila sistem hukum yang terdiri dari unsur substansi hukum, struktur hukum dan budaya hukum dalam suatu masyarakat bekerja saling mendukung di dalam pelaksanaannya.

Dari dua pendapat tersebut dapat diambil kesimpulan, bahwa kepastian hukum ditentukan oleh ketentuan peraturan perundangan, proses pelaksanaannya dan manfaat yang akan diperoleh serta terselenggaranya hubungan yang bersifat positif dan saling mendukung antara pihak pengambil keputusan dengan masyarakat untuk menciptakan konsistensi tujuan hukum yang diharapkan.

Bertitik tolak dari dua teori tersebut, maka dalam konteks kepastian hukum hak milik atas tanah, yang pada dewasa ini menunjukkan bahwa produk hukum yang memenuhi substansi hukum dan struktur hukum belum menjamin diperolehnya kepastian hukum dari sudut pandang sosiologi hukum. Kepastian hukum meliputi unsur kepastian hak, kepastian subyek dan kepastian obyek. Unsur-unsur kepastian 
hukum tersebut berkaitan dengan efektifitas hukum yang meliputi unsur substansi hukum, struktur hukum dan budaya hukum dalam suatu masyarakat.

Dari uraian tersebut dapat dikemukakan bahwa masyarakat secara individu maupun kelompok adalah bagian dari proses penerbitan produk hukum pelayanan pertanahan, maka maka dari sudut pandang sosiologi hokum, keterlibatan masyarakat secara individu maupun kelompok sangat strategis dan perlu dilibatkan secara aktif. Dengan demikian masyarakatpun juga akan berperan dalam memberikan kepastian hukum kepemilikan tanah dan juga merupakan salah satu realita lembaga peradilan di luar lembaga formal yang telah ada.

\section{c. Sudut Pandang Ekonomi Hukum Pertanahan}

Kemajuan di bidang pertanahan telah memberikan kemampuan ekonomi yang bertambah baik bagi masyarakat yang tentu saja secara alamiah disusul dengan pertumbuhan penduduk dan ekonomi sedang persediaan lahan tanah jumlahnya relatif tetap, hal mana akan menimbulkan benturan-benturan kepentingan yang pada gilirannya akan menjadi sengketa yang berbuntut pengadilan. Mengkaji masalah hukum yang dapat dipandang dari sisi ekonomi dikemukakan oleh Achmad Ali (1998) seorang Pakar Hukum yang mengutarakan kajian empiris hukum ekonomi yang membedakan dengan kajian Hukum Ekonomi yang lebih bersifat normative tentang kegiatan Bisnis.

Analisis ekonomi terhadap persoalan hukum, juga mengalami perkembangan. Jika pada awal tahun 1960-an difokuskan pada pengaruh ekonomi terhadap peraturan yang bersifat industri, kewajiban ekonomi terhadap timbulnya suatu kecelakaan serta hukum terhadap perbuatan melawan hukum. Pada awal tahun 1970-an mulai menerapkan konsep-konsep ekonomi ke semua bidang hukum terutama dengan acuan "konsep efiensi ekonomi"

Kajian Hukum dan Ekonomi menurut Achmad Ali tersebut sekurang-kurangnya mampu menjawaab dua pertanyaan mendasar :

a. Efek apakah yang ditimbulkan aturan-aturan hukum terhadap masyarakat ?

b. Bagaimana kekuatan ekonomi membentuk dan menentukan hukum ?

Pendekatan hukum dan ekonomi yang mendasarkan pada aspek efisiensi ekonomi memungkinkan penyelesaian suatu perkara pertanahan di luar jalur pengadilan jika secara ekonomi dapat memuaskan kedua belah pihak yang berperkara. Artinya kompensasi ekonomi yang diterima pihak yang dirugikan akan lebih besar diterima katimbang jika perkara tersebut dibawa ke pengadilan, termasuk resiko politik, sosial dan budaya. Demikian pula sekalipun perkara tersebut telah berada pada jalur pengadilan, namun para Hakim maupun Pengacara selalu menawarkan pendekatan ekonomi kepada pihak yang bersengketa dengan menggunakan prinsip efisiensi ekonomi.

\section{d. Analisis Putusan Hakim Terhadap Kasus Pertanahan di Lokasi Sampel}


Dari lokasi sampel yang sudah dilaksanakan penelitian, kasus/sengketa pertanahan umumnya merupakan sengketa kepemilikan dimana salah satu pihak meminta pembatalan sertipikat. Sengketa ini terjadi karena antara lain karena pemekaran wilayah dan lemahnya alas hak yang dimiliki, ada yang berupa Surat Izin Menghuni (SIM) tahun 1964, hibah dan pembagian warisan bawah tangan, keabsahan akta jual beli dan sebagainya.

Kasus-kasus/sengketa pertanahan yang disidangkan di PTUN merupakan sengketa tata usaha negara yaitu sengketa yang timbul dalam bidang tata usaha negara antara orang atau badan hukum privat dengan Badan atau Pejabat Tata Usaha Negara sebagai akibat dikeluarkannya keputusan tata usaha negara (pasal 1 angka 5), keputusan tata usaha negara tersebut adalah suatu penetapan tertulis yang dikeluarkan oleh Badan atau Pejabat Tata Usaha Negara yang berisi tindakan hukum tata usaha negara berdasarkan peraturan perundangan yang berlaku, bersifat konkrit, individual dan final serta menimbulkan akibat hukum bagi seseorang atau badan hukum privat.

Hakim PTUN akan menggunakan tolok ukur sebagai pengujian yaitu pasal 53 ayat (2) a, b, c UndangUndang Nomor 5 Tahun 1986 bahwa surat keputusan dapat dinyatakan batal atau tidak sah apabila keputusan tersebut dikeluarkan:

a. bertentangan dengan peraturan perundangundangan yang berlaku

b. melampaui batas kewenangan

c. dengan sewenang-wenang

Dalam pertimbangan hukum hakim TUN sering pula menyebutkan bahwa pejabat TUN (dalam hal ini BPN) telah melakukan perbuatan yang bertentangan dengan nilai-nilai yang terkandung dalam AsasAsas Umum Pemerintahan Yang Baik (AAUPB).

Disisi lain Hakim PTUN menganggap bahwa Kantor Pertanahan seharusnya berpedoman pada PP PP No. 24 tahun 1997 bukan dengan peraturan lain di bawahnya (surat edaran menteri) dan peraturan menteri/Kepala BPN sehingga hakim tidak pernah mempertimbangkan peraturan di bawahnya yang merupakan peraturan operasional BPN. Hakim menganggap peraturan dibawah PP No. 24 tahun 1997 harus sejalan dengan peraturan yang lebih tinggi.

Untuk sengketa pertanahan yang disidangkan di Peradilan Umum, Hakim umumnya mengacu pada ketentuan/azas hukum perdata dalam Kitab Undang-Undang Hukum Perdata, dari 5 putusan tersebut di atas Hakim tidak pernah mengacu pada ketentuan hukum tanah nasional dan peraturan operasional yang menjadi landasan kerja BPN seharusnya juga dijadikan bahan pertimbangan hakim.

Majelis hakim dalam pertimbangan hukumnya sering mempertanyakan legalitas dari akta jual beli yang dilakukan pemohon balik nama, padahal BPN tidak mempunyai hak uji materiil terhadap legalitas data yang diajukan pemohon karena sepanjang itu sah sudah ditandatangani pejabat yang berwenang, patutlah dianggap benar. 
Sertipikat yang merupakan tanda bukti hak dan merupakan alat pembuktian yang kuat dapat dinyatakan batal (van rechtswegenietig) atas alasan adanya unsur onrechtmatige daad (perbuatan melawan hukum) pasal 1365 KUHPer, dwang dwaling dan bedrog (pasal 1452 KUHS), adanya itikad buruk (pasal 1362 KUHPer).

\section{BAB V \\ UPAYA MENGATASI SENGKETA PERTANAHAN \\ DI LEMBAGA PERADILAN}

Sebagai upaya untuk mengeliminir meningkatnya sengketa pertanahan akan mempengaruhi kepercayaan masyarakat terhadap pejabat atau aparat BPN dan produk yang dihasilkannya yaitu sertipikat tanah sebagai jaminan kepastian hukum, dipandang perlu untuk melakukan beberapa alternatif pemecahannya.

\section{A. Penyempurnaan Peraturan Pertanahan}

Salah satu aspek penting dari tujuan hukum adalah kepastian hukum artinya hukum berkehendak untuk menciptakan kepastian hukum dalam hubungan orang dalam masyarakat. salah satu yang berhubungan erat dengan kepastian hukum adalah darimana hukum itu berasal. Sebagai sumber hukum, peraturan peruindag-undangan diartikan sebagai keputusan tertulis yang dikeluarkan oleh lembaga yang berwenang berisi aturan yang mengikat secara umum, dan dapat berisi ketentuan mengenai hak, kewajiban, fungsi atau status.

Tujuan diberlakukannya Undang Undang Pokok Agraria antara lain adalah meletakkan dasar-dasar untuk memberikan kepastian hukum mengenai hak-hak atas tanah bagi rakyat seluruhnya. Pasal 19 Undang Undang Pokok Agraria merupakan landasan hukum pendaftaran tanah di Indonesia, peraturan pelaksanaannya Peraturan Pemerintah Nomor 10 Tahun 1961, kemudian disempurnakan dengan Peraturan Pemerintah Nomor 24 Tahun 1997 dengan tetap mempertahankan prinsip-prinsip yang dianut, antara lain tujuan dan sistem yang digunakan dalam pelaksanaan pendafataran tanah, sistem publikasi adalah sistem negatif yang mengandung unsur positif, karena akan menghasilkan surat-surat tanda bukti hak yang berlaku sebagai alat pembuktian yang kuat (pasal 19 ayat (2), pasal 23 ayat (2), pasal 32 , ayat (2), pasal 38 ayat (2) Undang Undang Pokok Agraria). Penyempurnaan yang diadakan meliputi penegasan berbagai hal yang belum jelas dalam peraturan yang lama.

Setelah berlakunya Peraturan Pemerintah Nomor 24 Tahun 1997 selama lebih kurang 7 (tujuh) tahun ada beberpa pasal yang menimbulkan benturan dengan peraturan lain dan menimbulkan permasalahan dalam pelaksanaannya.

Dari 14 Kabupaten dan Kota Sampel seluruhnya mengusulkan bahwa Peraturan Pemerintah Nomor 24 tahun 1997 perlu disempurnakan dengan memasukkan beberapa klausul yang sangat penting untuk mengurangi resiko yang dapat terjadi sebagai akibat pelaksanaan proses pendaftaran tanah. Klausul yang perlu dipertimbangkan untuk dimasukkan dalam revisi Peraturan Pemerintah Nomor 24 tahun 1997 antara lain : 
a. pasal yang menyatakan bahwa BPN memproses haknya berdasarkan bukti yang diajukan oleh pemohon dan keterangan dari Kepala Desa (BPN tidak mempunyai hak uji materiil). Selama ini jika terjadi pemalsuan alas hak yang dibuat Kepala Desa, BPN selalu dikenakan pasal 55 dan 56 KUHPidana, yaitu dianggap membantu kejahatan.

b. personen recht yang ikut terlibat dalam pembuatan sertipikat harus bertanggung jawab, artinya tanggung jawab melekat pada masing-masing TUPOKSI, sehingga juru ukur beranggung jawab jika terjadi kesalahan atas surat ukur yang dibuatnya.

c. pasal 45 Peraturan Pemerintah Nomor 24 tahun 1997, Kakantah menolak melakukan pendaftaran peralihan atau pembebanan hak, jika tanah yang bersangkutan merupakan obyek sengketa Pengadilan, pasal ini bertentangan dengan pasal 67 Undang-Undang Nomor 5 tahun 1986 bahwa gugatan tidak menunda dilaksanakannya Keputusan TUN.

d. Pasal 32 Peraturan Pemerintah Nomor 24 tahun 1997 bertentangan dengan pasal 14 ayat (1) Undang-Undang Nomor 14 tahun 1970 tentang Pokok-Pokok Kekuasaan Kehakiman bahwa Pengadilan tidak boleh menolak untuk memeriksa dan mengadili suatu perkara yang diajukan dengan dalil bahwa hukum tidak atau kurang jelas. Pasal 32 Peraturan Pemerintah Nomor 24 tahun 1997 pada pokoknya menyatakan bahwa atas suatu bidang tanah sudah diterbitkan sertipikat secara sah maka pihak lain yang merasa mempunyai hak atas tanah tidak dapat lagi menuntut pelaksanaan hak tersebut apabila dalam waktu 5 tahun sejak diterbitkannya sertipikat itu tidak mengajukan gugatan ke Pengadilan. Pasal 32 harus dibuat dengan syarat-syarat tertentu dan mekanisme pengumuman yang dilakukan juga harus dicantumkan dalam pasal ini.

e. perlu dimasukkan pasal mengenai tim bantuan hukum jika terjadi sengketa akibat pendaftaran tanah

f. Dalam Undang-Undang Nomor 18 tahun 2003 tentang Advokat tidak boleh lagi ada kuasa hukum PMP, harus diserahkan pada advokat, sehingga perlu diatur lagi mengenai penanganan masalah jika terjadi gugatan.

Tabel : 5 A

Alternatif Solusi Pemecahan Masalah Sengketa Pertanahan Melalui Penyempurnaan Peraturan Menurut Responden Kanwil BPN.

\begin{tabular}{|c|c|c|c|}
\hline No & $\begin{array}{l}\text { Responden } \\
\text { Kanwil } \\
\text { BPN }\end{array}$ & $\begin{array}{l}\text { Sumber } \\
\text { Peraturan }\end{array}$ & Formulasi Penyempurnaan \\
\hline 1 & 2 & 3 & 4 \\
\hline 1. & Jawa Barat & $\begin{array}{l}\text { - Penyempurnaan } \\
\text { PP No. 24/1997 }\end{array}$ & $\begin{array}{l}\text { perlu dimasukkan pasal mengenai tim bantuan hukum jika terjadi sengketa } \\
\text { akibat pendaftaran tanah }\end{array}$ \\
\hline 2. & $\begin{array}{l}\text { Kalimantan } \\
\text { Timur }\end{array}$ & $\begin{array}{l}\text { Penyempurnaan } \\
\text { PP No. 24/1997 }\end{array}$ & $\begin{array}{l}\text { - Jangka waktu pengajuan gugatan terhadap penerbitan sertipikat yang } \\
\text { dibatasi selama } 5 \text { tahun sejak diterbitkan sertipikat, sebagaimana datur } \\
\text { dalam Ps } 32 \text { ayat (2) Peraturan Pemerintah } 24 \text { 1997, karena para praktisi } \\
\text { hukum terutama para Hakim terdapat perbedaan pendapat dan } \\
\text { mengesampingkan pasal tersebut karena pengajuan gugatan ke lembaga } \\
\text { peradilan tidak mengenal kadaluwarsa dan merupakan hak seseorang. }\end{array}$ \\
\hline \multirow[t]{2}{*}{1} & 2 & 3 & 4 \\
\hline & & & - Pendapat lain bahwa Undang Undang Pokok Agraria berdasarkan Hukum \\
\hline
\end{tabular}




\begin{tabular}{|c|c|c|c|}
\hline & & & Adat, sedangkan dalam Hukum Adat tidak mengenal kadaluwarsa. \\
\hline 3. & $\begin{array}{l}\text { Sulawesi } \\
\text { Selatan }\end{array}$ & - & - \\
\hline 4. & $\begin{array}{l}\text { Sulawesi } \\
\text { Utara }\end{array}$ & $\begin{array}{l}\text { Pelaksanaan PP } \\
\text { No. } 24 \text { Tahun } 1997 \\
\text { secara konsisten } \\
\text { dan menyeluruh } \\
\text { karena saat ini } \\
\text { tidak seluruh pasal } \\
\text { diterapkan, } \\
\text { misalnya masalah } \\
\text { pengumuman data } \\
\text { fisik dan data } \\
\text { yuridis }\end{array}$ & - \\
\hline 5. & Sumbar & $\begin{array}{l}\text { Penyempurnaan } \\
\text { PP No. } 24 \text { Tahun } \\
1997\end{array}$ & $\begin{array}{l}\text { - Ps } 32 \text { PP No. 24/1997 bertentangan dengan Ps } 14 \text { (1) UU No. 14/1970 } \\
\text { tentang Pokok-Pokok Kekuasaan Kehakiman bahwa pengadilan tdk boleh } \\
\text { menolak untuk memeriksa dan mengadili suatu perkara. Sedangkan Ps } 32 \\
\text { PP No. 24/1997, menyatakan bahwa setelah sertipikat diterbitkan pihak lain } \\
\text { yang merasa mempunyai hak atas tanah tidak dapat lagi menuntut } \\
\text { pelaksanaan hak tersebut apabila dlm waktu } 5 \text { th sejak diterbitkan sertipikat } \\
\text { tidak mengajukan keberatan secara tertulis kepada pemegang sertipikat dan } \\
\text { Kakantah atau tidak mengajukan gugatan ke pengadilan. }\end{array}$ \\
\hline 1 & 2 & 3 & 4 \\
\hline & & & $\begin{array}{l}\text { - Pasal } 45 \text { Peraturan Pemerintah No. 24/1997 bertentangan dengan Pasal } 67 \\
\text { Undang-Undang Nomor 5/1986 bahwa gugatan tidak menunda } \\
\text { dilaksanakannya keputusan TUN sedangkan Pasal } 45 \text { Peraturan Pemerintah } \\
\text { Nomor 24/1997 menyatakan bahwa Kakantah menolak untuk melakukan } \\
\text { pendaftaran peralihan atau pembebanan hak jika tanah yang bersangkutan } \\
\text { merupakan obyek sengketa di pe-ngadilan. } \\
\text { - Pasal } 32 \text { perlu direvisi }\end{array}$ \\
\hline 6. & $\begin{array}{l}\text { Kalimantan } \\
\text { Selatan }\end{array}$ & - & - \\
\hline 7. & $\begin{array}{l}\text { Kalimantan } \\
\text { Barat }\end{array}$ & - & - \\
\hline 8. & $\begin{array}{l}\text { Sumatera } \\
\text { Utara }\end{array}$ & - & - \\
\hline
\end{tabular}

Tabel : 5 B

Alternatif Solusi Pemecahan Masalah Sengketa Pertanahan Melalui Penyempurnaan Peraturan Menurut Responden Kantor Pertanahan.

\begin{tabular}{|c|c|c|c|}
\hline No. & $\begin{array}{c}\text { Responden } \\
\text { Kantah }\end{array}$ & Sumber Peraturan & Formulasi Penyempurnaan \\
\hline 1 & $\mathbf{2}$ & $\mathbf{3}$ & $\mathbf{4}$ \\
\hline 1 & $\begin{array}{l}\text { Kota/Kab. } \\
\text { Bandung }\end{array}$ & $\begin{array}{l}\text { - Penyempurnaan } \\
\text { PP No. 24/1997 }\end{array}$ & $\begin{array}{l}\text { - Seharusnya ada pasal yang menyatakan bahwa BPN memproses haknya } \\
\text { berdasarkan bukti yang diajukan oleh pemohon dan keterangan dari } \\
\text { Kepala Desa (BPN tidak mempunyai hak uji }\end{array}$ \\
\hline \hline
\end{tabular}




\begin{tabular}{|c|c|c|c|}
\hline 1 & 2 & 3 & 4 \\
\hline & & & $\begin{array}{l}\text { materiil). } \\
\text { - adanya personen recht yang ikut terlibat dalam pembuatan sertipikat } \\
\text { sehingga jelas titik-titik merah di pelayanan yang bertanggung jawab, } \\
\text { secara formal Kakan yang menanda tangani, secara material, pada } \\
\text { masing-masing tupoksi. } \\
\text { - ps } 45 \text { PP No } 24 \text { tahun 1997, Kakantah menolak melakukan pendaftaran } \\
\text { peralihan atau pembebanan hak, jika tanah yang bersangkutan meru- } \\
\text { pakan obyek sengketa Pengadilan, pasal ini bertentangan dengan pasal } 67 \\
\text { UU Nomor } 5 \text { tahun } 1986 \text { bahwa gugatan tidak menunda dilaksanakannya } \\
\text { Keputusan TUN. } \\
\text { - Ps } 32 \text { PP No } 24 \text { tahun } 1997 \text { bertentangan dengan pasal } 14 \text { ayat (1) } \\
\text { Undang-Undang Nomor } 14 \text { tahun } 1970 \text { tentang Pokok-Pokok Kekuasaan } \\
\text { Kehakiman bahwa Pengadilan tidak boleh menolak untuk memeriksa dan } \\
\text { mengadili suatu perkara yang diajukan dengan dalil bahwa hukum tidak } \\
\text { atau kurang jelas. } \\
\text { Ps } 32 \text { PP No } 24 \text { tahun } 1997 \text { pada pokoknya menyatakan bahwa atas } \\
\text { suatu bidang tanah sudah diterbitkan sertipikat secara sah maka }\end{array}$ \\
\hline 1 & 2 & 3 & 4 \\
\hline & & - & $\begin{array}{l}\text { pihak lain yang merasa mempunyai hak atas tanah tidak dapat lagi menuntut } \\
\text { pelaksanaan hak tersebut apabila dalam waktu } 5 \text { tahun sejak diterbitkannya } \\
\text { sertipikat itu tidak mengajukan gugatan ke Pengadilan . }\end{array}$ \\
\hline 2. & $\begin{array}{l}\text { Kota } \\
\text { Samarinda/ } \\
\text { Balikpapan }\end{array}$ & $\begin{array}{l}\text { Penyempurnaan PP } \\
\text { No. } 24 / 1997\end{array}$ & $\begin{array}{l}\text { - Seharusnya ada pasal yang menyatakan lebih tegas bahwa BPN } \\
\text { memproses haknya berdasarkan bukti yang diajukan oleh pemohon dan } \\
\text { keterangan dari Kepala Desa sesuai peraturan yang berlaku (BPN tidak } \\
\text { mempunyai hak uji materiil) } \\
\text { - Pasal } 32 \text { Peraturan Pemerintah Nomor } 24 \text { tahun } 1997 \text { tentang jangka } \\
\text { waktu pengajuan gugatan terhadap penerbitan sertipikat yang dibatasi } \\
\text { selama } 5 \text { tahun sejak diterbitkan sertipikat perlu ditinjau kembali. }\end{array}$ \\
\hline 3. & $\begin{array}{l}\text { Kota } \\
\text { Makasar/ } \\
\text { Kab.Gowa }\end{array}$ & $\begin{array}{l}\text { Penyempurnaan PP } \\
\text { No. } 24 / 1997\end{array}$ & - \\
\hline 4 & $\begin{array}{l}\text { Kota } \\
\text { Manado/ } \\
\text { Kab. } \\
\text { Minahasa }\end{array}$ & $\begin{array}{l}\text { Penyempurnaan PP } \\
\text { No. } 24 / 1997\end{array}$ & $\begin{array}{l}\text { - Pasal } 32 \text { PP No. } 24 \text { Tahun } 1997 \text { tentang daluarsa (rechverjaring) untuk } \\
\text { menggugat sertipikat setelah } 5 \text { (lima) tahun sebaiknya dimasukkan dalam } \\
\text { materi Undang-Undang } \\
\text { - Pasal } 32 \text { PP No. } 24 \text { Tahun } 1997 \text { perlu direvisi karena dalam prakteknya } \\
\text { aturan tersebut oleh lembaga peradilan/yudikatif seringkali dikesampingkan }\end{array}$ \\
\hline 5. & $\begin{array}{l}\text { Kota } \\
\text { Padang/ } \\
\text { Kab.Padang }\end{array}$ & $\begin{array}{l}\text { Penyempurnaan PP } \\
\text { No. } 24 / 1997\end{array}$ & $\begin{array}{l}\text { - Pasal } 32 \text { PP No. } 24 \text { Tahun } 1997 \text { bertentangan dengan Pasal } 14 \text { Ayat (1) } \\
\text { Undang-Undang Nomor } 14 \text { Tahun } 1970 \text { tentang Pokok-Pokok Kekuasaan } \\
\text { Kehakiman bahwa pengadilan tidak boleh menolak untuk memeriksa dan }\end{array}$ \\
\hline
\end{tabular}




\begin{tabular}{|c|c|c|c|}
\hline & Pariaman & & $\begin{array}{l}\text { mengadili suatu perkara. } \\
\text { - Dalam Pasal } 32 \text { Peraturan Pemerintah Nomor } 24 \text { Tahun 1997, } \\
\text { menyatakan bahwa setelah sertipikat diterbitkan maka pihak lain yang } \\
\text { merasa mempunyai hak atas tanah tidak dapat lagi menuntut pelaksanaan } \\
\text { hak terse-but apabila dalam jangka waktu } 5 \text { tahun sejak diterbitkannya } \\
\text { sertipikat tidak mengajukan keberatan secara tertulis kepada pemegang } \\
\text { sertipikat dan Kakantah atau tidak mengajukan gugatan ke pengadilan. } \\
\text { Pasal } 45 \text { Peraturan Pemerintah Nomor } 24 \text { Tahun } 1997 \text { bertentangan } \\
\text { dengan Pasal } 67 \text { UU Nomor } 5 \text { Tahun } 1986 \text { bahwa gugatan tidak menunda } \\
\text { dilak-sanakannya keputusan TUN sedangkan Pasal } 45 \text { PP Nomor } 24 \\
\text { Tahun } 1997 \text { menyatakan bah-wa Kakantah menolak untuk melakukan } \\
\text { pendaftaran perali-han atau pembeban hak jika tanah yang bersangkutan } \\
\text { merupakan obyek sengketa di pengadilan. }\end{array}$ \\
\hline 6. & $\begin{array}{l}\text { Kota } \\
\text { Banjarmasin } \\
\text { / } \\
\text { Kab. Banjar }\end{array}$ & $\begin{array}{l}\text { Penyempurnaan PP } \\
\text { No. 24/1997 }\end{array}$ & $\begin{array}{l}\text { - Seharusnya ada pasal yang menyatakan bahwa BPN memproses haknya } \\
\text { berdasarkan bukti yang diajukan oleh pemohon dan keterangan dari } \\
\text { Kepala Desa (BPN tidak mempunyai hak uji materiil) } \\
\text { - adanya personen recht yang ikut terlibat dalam pembuatan sertipikat } \\
\text { sehingga jelas titik-titik merah di pelayanan yang bertanggung jawab, } \\
\text { secara formal Kakan yang menanda tangani, secara material, pada } \\
\text { masing-masing tupoksi } \\
\text { pasal } 45 \text { PP Nomor } 24 \text { tahun 1997, Kakantah menolak melakukan } \\
\text { pendaftaran peralihan atau pembebanan hak, jika tanah yang } \\
\text { bersangkutan merupakan obyek sengketa Pengadilan, pasal ini } \\
\text { bertentangan dengan pasal } 67 \text { Undang-Undang Nomor } 5 \text { tahun } 1986 \\
\text { bahwa gugatan tidak menunda dilaksanakannya Keputusan TUN. }\end{array}$ \\
\hline 7. & $\begin{array}{l}\text { Kota } \\
\text { Pontianak/ } \\
\text { Kab } \\
\text { Pontianak }\end{array}$ & $\begin{array}{l}\text { Penyempurnaan PP } \\
\text { No. 24/1997 }\end{array}$ & $\begin{array}{l}\text { - Seharusnya ada pasal yang menyatakan lebih tegas bahwa BPN } \\
\text { memproses haknya berdasarkan bukti yang diajukan oleh pemohon dan } \\
\text { keterangan dari Kepala Desa sesuai peraturan yang berlaku (BPN tidak } \\
\text { mempunyai hak uji materiil) } \\
\text { Pasal } 32 \text { Peraturan Pemerintah Nomor } 24 \text { tahun } 1997 \text { tentang jangka } \\
\text { waktu pengajuan gugatan terhadap penerbitan sertipikat yang dibatasi } \\
\text { selama } 5 \text { tahun sejak diterbitkan sertipikat perlu ditinjau kembali. }\end{array}$ \\
\hline 8. & $\begin{array}{l}\text { Sumatera } \\
\text { Utara }\end{array}$ & $\begin{array}{l}\text { Penyempurnaan PP } \\
\text { No. 24/1997 }\end{array}$ & \\
\hline
\end{tabular}




\section{B. Koordinasi dan Sosialisasi Peraturan Pertanahan}

Seluruh responden beranggapan Koordinasi dan Sosialisasi Peraturan Pertanahan masih sangat kurang sehingga menimbulkan persepsi yang berbeda dalam memahami peraturan pertanahan antara hakim, aparat BPN maupun instansi terkait. Oleh karenanya sangat penting untuk meningkatkan koordinasi dan sosialisasi sehingga diperoleh pemahaman yang sama dalam penanganan sengketa pertanahan.

Mekanisme koordinasi dan sosialisasi dapat dilakukan dengan para hakim peradilan baik peradilan umum maupun TUN, Instansi Pemerintah yang terkait dengan masalah pertanahan seperti Pemerintah Daerah, Tokoh Masyarakat Adat, PPAT, Kepolisian, Lurah atau Camat dan sebagainya melalui seminar atau diskusi, rapat koordinasi, penyuluhan hukum pertanahan, dan sebagainya.

Tabel : 6 A

Alternatif Solusi Pemecahan Masalah Sengketa Pertanahan Melalui Koordinasi \& Sosialisasi Peraturan-Peraturan Menurut Responden Kanwil BPN .

\begin{tabular}{|c|c|c|c|}
\hline No. & $\begin{array}{l}\text { Responden } \\
\text { Kanwil BPN }\end{array}$ & $\begin{array}{l}\text { Pelaksanaan saat ini dan } \\
\text { implikasinya }\end{array}$ & Pelaksanaan yang akan datang dan implikasinya \\
\hline 1 & 2 & 3 & 4 \\
\hline 1 & Jawa Barat & $\begin{array}{l}\text { - Koordinasi dan Sosialisasi } \\
\text { Peraturan Pertanahan masih } \\
\text { sangat kurang }\end{array}$ & Perlu ditingkatkan \\
\hline 2 & $\begin{array}{l}\text { Kalimantan } \\
\text { Timur }\end{array}$ & 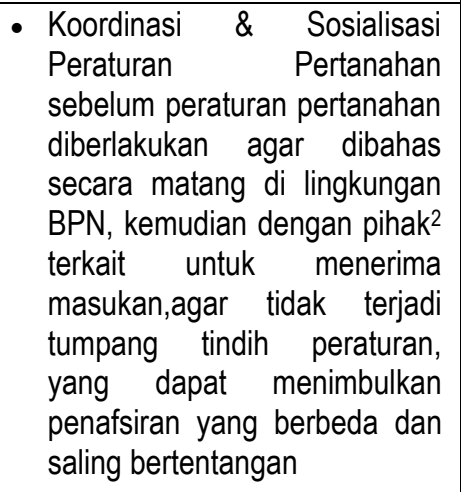 & Perlu ditingkatkan \\
\hline 3 & Sulsel & - Koordinasi kurang & pihak BPN perlu lebih aktif berkoordinasi dg Peradilan TUN \\
\hline 4 & Sulut & $\begin{array}{l}\text { Koordinasi dan sosi alisasi } \\
\text { peraturan pertanahan masih } \\
\text { kurang }\end{array}$ & $\begin{array}{l}\text { Penyuluhan hukum secara terpadu dengan instansi terkait } \\
\text { - MA, } \\
\text { - Depkum dan HAM, } \\
\text { - dsb }\end{array}$ \\
\hline 1 & 2 & 3 & $\begin{array}{l} \\
\end{array}$ \\
\hline 5 & Sumbar & $\begin{array}{l}\text { Koordinasi dan sosialisasi perlu } \\
\text { di-lakukan terhadap para KAN, } \\
\text { hakim, Instansi Pemerintah,PPAT } \\
\text { dan stakeholders terkait lain-nya. }\end{array}$ & $\begin{array}{l}\text { Kerjasama dengan para stake-holders } \text { (hakim,KAN, } \\
\text { Instansi Pemerintah,PPAT/ } \\
\text { Notaris melalui diskusi-diskusi dan } \\
\text { menginformasikan setiapperkembangan peraturan di }\end{array}$ \\
\hline
\end{tabular}




\begin{tabular}{|c|c|c|c|}
\hline & & & $\begin{array}{l}\text { bidang pertanahan } \\
\text { terutama kepada para hakim. }\end{array}$ \\
\hline 6 & $\begin{array}{l}\text { Kalimantan } \\
\text { Selatan }\end{array}$ & $\begin{array}{l}\text { Koordinasi dan Sosialisasi } \\
\text { Peraturan Pertanahan masih } \\
\text { sangat kurang }\end{array}$ & Perlu ditingkatkan \\
\hline 7 & $\begin{array}{l}\text { Kalimantan } \\
\text { Barat }\end{array}$ & 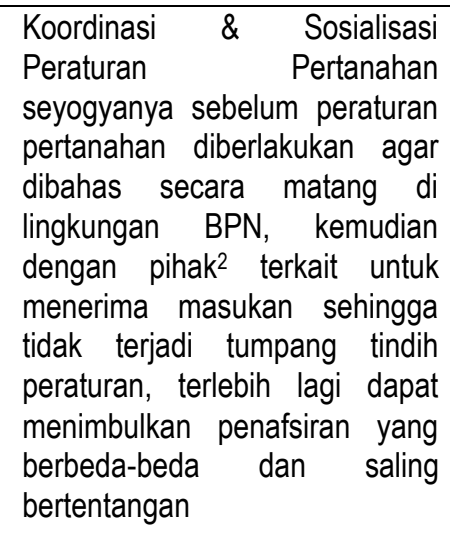 & Perlu ditingkatkan \\
\hline 8 & Sumut & $\begin{array}{l}\text { Koordinasi dan sosialisasi perlu } \\
\text { di-lakukan terhadap para hakim, } \\
\text { Instansi Pemerintah dan } \\
\text { stakeholders terkait lainnya. }\end{array}$ & - \\
\hline
\end{tabular}

Tabel : 6 B

Alternatif Solusi Pemecahan Masalah Sengketa Pertanahan Melalui Koordinasi \& Sosialisasi Peraturan-Peraturan Menurut Responden Kantor Pertanahan.

\begin{tabular}{|c|c|c|c|}
\hline No. & $\begin{array}{l}\text { Responden } \\
\text { Kantah }\end{array}$ & $\begin{array}{c}\text { Pelaksanaan saat ini dan } \\
\text { implikasinya }\end{array}$ & Pelaksanaan yang akan datang dan implikasinya \\
\hline 1 & 2 & 3 & 4 \\
\hline 1 & $\begin{array}{l}\text { Kota/Kab. } \\
\text { Bandung }\end{array}$ & $\begin{array}{l}\text { - Koordinasi dan Sosialisasi } \\
\text { Peraturan Pertanahan masih } \\
\text { sangat kurang }\end{array}$ & $\begin{array}{l}\text { Kantah Kota Bandung lebih setuju dengan alternatif ini agar } \\
\text { peraturan pertanahan dapat dijadikan acuan dalam } \\
\text { pengambilan keputusan oleh Hakim di Pengadilan }\end{array}$ \\
\hline 2 & $\begin{array}{l}\text { Kota } \\
\text { Samarinda/ } \\
\text { Balikpapan }\end{array}$ & $\begin{array}{l}\text { - Koordinasi dan Sosialisasi } \\
\text { Peraturan Pertanahan dengan } \\
\text { pihak-pihak terkait masih } \\
\text { sangat kurang } \\
\text { - Perlu adanya pelatihan kepada } \\
\text { petugas yang menangani } \\
\text { perma- }\end{array}$ & $\begin{array}{l}\text { Semestinya sengketa pertanahan dapat diselesaikan } \\
\text { secara musyawarah, dan seyogyanya produk BPN dapat } \\
\text { diselesaikan }\end{array}$ \\
\hline & & $\begin{array}{l}\text { - salahan pertanahan/kuasa } \\
\text { hukum dalam hal berperkara } \\
\text { secara rutin untuk peningkatan } \\
\text { mutu SDM } 1 \text { s/d } 2 \text { kali per } \\
\text { tahun. } \\
\text { - Walikota berkoordinasi dengan }\end{array}$ & $\begin{array}{l}\text { melalui peradilan TUN serta peraturan pertanahan dapat } \\
\text { dijadikan acuan dalam pengambilan keputusan oleh Hakim } \\
\text { di Pengadilan }\end{array}$ \\
\hline
\end{tabular}




\begin{tabular}{|c|c|c|c|}
\hline & & $\begin{array}{l}\text { Kantor Pertanahan melarang } \\
\text { Lurah \& Camat membuat surat } \\
\text { keterangan tanah untuk tanah } \\
\text { negara. }\end{array}$ & \\
\hline 3 & $\begin{array}{l}\text { Kota } \\
\text { Makasar/Kab. } \\
\text { Gowa }\end{array}$ & $\begin{array}{l}\text { Koordinasi dan sosialisasi } \\
\text { peraturan pertanahan masih } \\
\text { perlu ditingkatkan }\end{array}$ & - - \\
\hline 1 & 2 & 3 & 4 \\
\hline 4 & $\begin{array}{l}\text { Kota } \\
\text { Manado/Kab. } \\
\text { Minahasa }\end{array}$ & $\begin{array}{l}\text { Koordinasi dan sosialisasi } \\
\text { peraturan pertanahan masih } \\
\text { kurang }\end{array}$ & $\begin{array}{l}\text { - adanya lembaga formal yang dapat menjadi fasilitator } \\
\text { dalam koordinasi dan sosialisasi } \\
\text { - seminar pertanahan dengan melibatkan instansi terkait } \\
\text { seperti pengadilan, kepolisian, kejaksaan, dan } \\
\text { Pemerintah Daerah }\end{array}$ \\
\hline 5 & $\begin{array}{l}\text { Kota Padang/ } \\
\text { Kab.Padang } \\
\text { Pariaman }\end{array}$ & $\begin{array}{l}\text { Koordinasi dan sosialisasi } \\
\text { perlu di-lakukan terhadap para } \\
\text { KAN, hakim, Peraturan } \\
\text { Pemerintah AT dan } \\
\text { stakeholders terkait lain-nya }\end{array}$ & $\begin{array}{l}\text { - Sosialisasi peraturan-peraturan per-tanahan } \\
\text { bekerjasama dengan pihak pihak terkait seperti dengan } \\
\text { melibat kan KAN dan para hakim. }\end{array}$ \\
\hline 6 & $\begin{array}{l}\text { Kota } \\
\text { Banjarmasin/ } \\
\text { Kab. Banjar }\end{array}$ & $\begin{array}{l}\text { - Koordinasi dan Sosialisasi } \\
\text { Peraturan Pertanahan masih } \\
\text { sangat kurang }\end{array}$ & $\begin{array}{l}\text { - Kantah kabupaten Banjar lebih setuju dengan alternatif } \\
\text { ini agar peraturan pertanahan dapat dijadikan acuan } \\
\text { dalam pengambilan keputusan oleh Hakim di Pengadilan } \\
\text { - }\end{array}$ \\
\hline 1 & 2 & 3 & 4 \\
\hline 7 & $\begin{array}{l}\text { Kota } \\
\text { Pontianak } \\
\text { /Kab. } \\
\text { Pontianak }\end{array}$ & $\begin{array}{l}\text { - Koordinasi dan Sosialisasi } \\
\text { Peraturan Pertanahan dengan } \\
\text { pihak-pihak terkait masih } \\
\text { sangat kurang }\end{array}$ & $\begin{array}{l}\text { - Semestinya sengketa pertanahan dapat diselesaikan } \\
\text { secara musyawarah, dan seyogyanya produk BPN } \\
\text { dapat diselesaikan melalui peradilan TUN serta } \\
\text { peraturan pertanahan dapat dijadikan acuan dalam } \\
\text { pengambilan keputusan oleh Hakim di Pengadilan }\end{array}$ \\
\hline 8 & Kota Medan. & $\begin{array}{l}\text { Koordinasi dan sosialisasi } \\
\text { peraturan pertanahan masih perlu } \\
\text { ditingkatkan }\end{array}$ & $\cdot-$ \\
\hline
\end{tabular}

\section{Kemungkinan Pembentukan Peradilan Khusus Pertanahan}

Kompetensi Peradilan merupakan salah satu aspek yang penting untuk mencapai suatu kepastian hukum. Kompetensi relatif mengatur tentang kedudukan pengadilan yang mempunyai wilayah (yurisdiksi) manakah yang berwenang untuk memeriksa dan mengadili suatu perkara. Kompetensi absolut mengatur tentang lembaga peradilan yang manakah yang berwenang untuk memeriksa dan mengadili suatu perkara dalam hal ini adalah untuk menentukan ruang lingkup peradilannya. Dalam UU No. 4 tahun 2004, lembaga peradilan meliputi peradilan umum, peradilan agama, peradilan militer dan peradilan tata usaha negara.

Sengketa pertanahan dapat diajukan ke peradilan umum jika menyangkut keperdataan dan dapat diajukan ke peradilan TUN jika menyangkut administrasi. Yang menimbulkan permasalahan adalah jika putusan lembaga peradilan atas satu obyek tanah sengketa yang sama ternyata saling bertentangan satu sama lain, yaitu antara putusan Peradilan TUN dengan Peradilan Umum (perdata/ pidana).

Adanya putusan lembaga peradilan yang bertentangan akan berpengaruh terhadap produk pelayanan pertanahan yaitu sertipikat hak atas tanah dan pejabat yang menanda tanganinya, padahal baik pejabat selaku pihak yang melaksanakan tugas maupun sertipikat hak atas tanah 
sebagai produknya tersebut dilindungi oleh undang-undang yang saha, dalam hal ini UU No. 5 tahun 1960 dan peraturan pelaksanaannya.

Tabel 7A

Alternatif Solusi Pemecahan Masalah Sengketa Pertanahan Melalui Kemungkinan Pembentukan Peradilan Khusus Pertanahan Menurut Responden Kanwil BPN .

\begin{tabular}{|c|c|c|}
\hline No. & $\begin{array}{l}\text { Responden } \\
\text { Kanwil BPN }\end{array}$ & Tujuan dan Sasaran \\
\hline 1 & 2 & 3 \\
\hline 1 & Jawa Barat & - Belum perlu, yang diperlukan pembentukan tim bantuan hukum jika terjadi gugatan \\
\hline 2 & Kalimantan Timur & $\begin{array}{l}\text { - Setuju dan agar dilakukan persiapan², pendekatan² ke pihak }{ }^{2} \text { pengambil kebijakan yang } \\
\text { berkompten dalam peningkatan SDM untuk berprofesional serta penyiapan kelembagaan } \\
\text { (organisasi) yang baik. }\end{array}$ \\
\hline 3 & Sulsel & - - \\
\hline 4 & Sulut & - Perlu diseminarkan dg melibatkan instansi terkait (MA, Depkeh, dll) \\
\hline 5 & Sumbar & $\begin{array}{l}\text { - Tidak perlu peradilan khusus per-tanahan karena sudah ada lembaga peradilan. Yang } \\
\text { perlu dilakukan adalah mengefektifkan dan meng-optimalkan lembaga peradilan yang ada } \\
\text { melalui sosialisasi dan kerja-sama. }\end{array}$ \\
\hline 6 & Kalimantan Selatan & - Belum perlu, yang diperlukan pembentukan tim bantuan hukum jika terjadi gugatan \\
\hline 1 & 2 & 3 \\
\hline 7 & Kalimantan Barat & $\begin{array}{l}\text { - Setuju dan agar dilakukan persiapan², pendekatan }{ }^{2} \text { ke pihak }^{2} \text { pengambil kebijakan yang } \\
\text { berkompeten dalam peningkatan SDM untuk berprofesional serta penyiapan } \\
\text { kelembagaan (organisasi) yang baik. }\end{array}$ \\
\hline 8 & Sumut & - Perlu disosialisasikan \\
\hline
\end{tabular}

Tabel : 7 B

Alternatif Solusi Pemecahan Masalah Sengketa Pertanahan Melalui Kemungkinan Pembentukan Peradilan Khusus Pertanahan Menurut Responden Kantor Pertanahan.

\begin{tabular}{|c|c|c|}
\hline No & Responden Kantah & Tujuan dan Sasaran \\
\hline 1 & Kota/Kab. Bandung & $\begin{array}{l}\text { - Kantah Kota Bandung kurang setuju, lebih efisien kalau Peradilan TUN yang } \\
\text { diberdayakan sehingga cukup dengan TUN saja tidak perlu ke Peradilan Umum } \\
\text { - Kantah Kab. Bandung setuju dengan pembentukan peradilan khusus pertanahan } \\
\text { karena kurangnya pemahaman hakim terhadap aturan pertanahan }\end{array}$ \\
\hline 2 & $\begin{array}{l}\text { Kota Samarinda/ } \\
\text { Balikpapan }\end{array}$ & $\begin{array}{l}\text { - Kantor Pertanahan setuju dengan pembentukan peradilan khusus pertanahan karena } \\
\text { kurangnya pemahaman hakim terhadap aturan pertanahan }\end{array}$ \\
\hline 3 & $\begin{array}{l}\text { Kota } \\
\text { Makasar/Kab.Gowa }\end{array}$ & $\begin{array}{l}\text { - Kantor Pertanahan Kota Makassar berpendapat bahwa saat ini belum perlu } \\
\text { membentuk lembaga peradilan khusus di bidang pertanahan, karena telah ada lembaga } \\
\text { peradilan TUN sebagai lembaga peradilan untuk mengadili produk pelayanan publik } \\
\text { termasuk pelayanan pertanahan. } \\
\text { - Kab.Gowa berpendapat bahwa BPN sudah waktunya menyiapkan Peradilan Khusus } \\
\text { Pertanahan karena Peradilan TUN dan Peradilan Umum tidak dapat secara efektif } \\
\text { memberikan pemecahan tentang kepastian hukum hak kepemilikan tanah. }\end{array}$ \\
\hline 1 & 2 & 3 \\
\hline 4 & $\begin{array}{l}\text { Kota Manado/Kab. } \\
\text { Minahasa }\end{array}$ & $\begin{array}{l}\text { - Kepala Kantah Kota Manado setuju dengan pembentukan peradilan pertanahan, namun } \\
\text { penyelesaian kasus-kasus pertanahan cukup diselesaikan melalui Peradilan } \\
\text { Umum/Peratun }\end{array}$ \\
\hline
\end{tabular}




\begin{tabular}{|c|l|l|}
\hline & & $\begin{array}{l}\text { - Kab. Minahasa ebih setuju dengan lembaga Arbitrase Pertanahan } \\
\text { - Perlu adanya Hakim Agung yang dari spesialisasi pertanahan/Agraria }\end{array}$ \\
\hline 5 & $\begin{array}{l}\text { Kota Padang/ } \\
\text { Kab.Padang } \\
\text { Pariaman }\end{array}$ & $\begin{array}{l}\text { - Kantah Kota Padang dan Kantah Kabupaten Padang Pariaman setuju dengan } \\
\text { dibentuknya peradilan khusus pertanahan sehingga penyelesaian perkara-perkara } \\
\text { pertanahan dapat diputus sesuai dengan peraturan pertanahan karena para hakimnya } \\
\text { mengetahui benar mengenai hukum pertanahan. Pem-bentukan peradilan ini sebaiknya } \\
\text { dengan Undang-Undang . }\end{array}$ \\
\hline 6 & $\begin{array}{l}\text { Kota } \\
\text { Banjarmasin/Kab. } \\
\text { Banjar }\end{array}$ & $\begin{array}{l}\text { - Kantah Kab. Bandjar setuju dengan pembentukan peradilan khusus pertanahan karena } \\
\text { kurangnya pemahaman hakim terhadap aturan pertanahan }\end{array}$ \\
\hline 7 & $\begin{array}{l}\text { Kota Pontianak/Kab. } \\
\text { Pontianak }\end{array}$ & $\begin{array}{l}\text { Kantor Pertanahan setuju dengan pembentukan peradilan khusus pertanahan karena } \\
\text { kurangnya pemahaman hakim terhadap aturan pertanahan }\end{array}$ \\
\hline 8 & Kota Medan & setuju dengan pembentukan peradilan khusus pertanahan \\
\hline
\end{tabular}

Dari 7 responden Kanwil BPN, 2 lokasi (Kalimantan Timur dan Kalimantan Barat) setuju dibentuk peradilan khusus pertanahan, namun sebelumnya perlu dilakukan persiapan nerupa seminar maupun pendekatan kepada pihak-pihak pengambil kebijakan yang berkompeten untuk peningkatan SDM yang profesional serta penyiapan kelembagaan (Organisasi) yang baik. Sedangkan responden lainnya beranggapan belum perlu dibentuk peradilan khusus pertanahan dan jika akan dibentuk perlu disosialisasikan terlebih dulu.

Untuk 14 responden Kantor Pertanahan, 11 responden setuju pembentukan peradilan khusus pertanahan dengan beberapa alasan sebagai berikut :

- kurangnya pemahaman hakim terhadap pemahaman hukum pertanahan,

- $\quad$ karena peradilan Umum dan TUN tidak dapat memberikan pemecahan tentang kepastian hukum kepemilikan tanah.

- Pembentukan Peradilan Pertanahan perlu segera direalisir mengingat proses panjang dalam pemeriksaan perkara dan

- $\quad$ tingginya volume perkara pertanahan.

Namun disadari pembentukan peradilan pertanahan dibutuhkan waktu dan biaya mengingat harus ada undang-undangnya terlebih dulu, kemudian sumberdaya manusia harus disediakan dari hakim karier dan non karier. Ada pendapat/usulan untuk memasukkannya dalam peradilan adhoc.

\section{Analisis Peluang Peradilan Khusus Pertanahan/Agraria}

\section{Potensi Sengketa Pertanahan di Lembaga Peradilan}

Di kalangan Kantor Pertanahan maupun Kantor Wilayah BPN terdapat perbedaan antara perlu tidaknya dibentuk Peradilan Khusus Pertanahan. Sebagian berpendapat bahwa saat ini belum perlu membentuk lembaga peradilan khusus di bidang pertanahan/agraria, karena telah ada lembaga peradilan TUN sebagai lembaga peradilan untuk mengadili produk-produk pelayanan publik termasuk pelayanan pertanahan. Masalahnya pihak BPN perlu lebih aktif berkoordinasi dengan Peradilan TUN. Sebagian lagi berpendapat bahwa BPN sudah waktunya menyiapkan Peradilan Khusus Pertanahan 
karena Peradilan TUN dan Peradilan Umum tidak efektif dalam memberikan pemecahan tentang kepastian hukum hak kepemilikan tanah.

Kiranya perlu disitir ucapan Hakim Ahung Howard Ryan dari Mahkamah Agung Negara Bagian Illionis, Amerika Serikat (Achmad Ali, 2004) :

"siapa yang tidak merasa schock ketika mengalami kenyataan betapa mereka harus menunggu setahun, bahkan dua tahun, tiga, empat atau lima tahun sebelum perkara mereka mendapat putusan yang final "

Berperkara di pengadilan menghabiskan biaya yang tidak sedikit. Penelitian di Amerika Serikat menunjukkan untuk suatu perkara yang nilai tuntutannya di bawah US $\$ 10000$ ternyata biaya yang harus dikeluarkan untuk membayar pengacara yang mengenakan tarip per jam, tidak jarang melebihi jumlah tersebut. Dalam hal ini sangat tepat ungkapan filosuf Perancis yang mewakili orang yang berperkara di pengadilan :

"saya mengalami kegagalan dua kali, sekali ketika saya memenangkan gugatan di pengadilan dan sekali lagi ketika saya memang kalah dalam perkara saya di pengadilan "

Kartini Sodjendro pakar hukum yang juga PPAT/Notaris dalam disertasinya menyatakan bahwa di kalangan PPAT/Notaris, karena fungsi gandanya dalam menjaga pelanggannya, terhadap aturan BPN sering berlaku istilah : "take it or leave it, Hal ini merupakan sinyal bahwa produk hukum PPAT yang semestinya mampu menjaga dan meningkatkan aspek positif kepemilikan tanah bahkan sebaliknya yaitu adanya produk produk PPAT yang berpotensi menimbulkan masalah pertanahan. Masalah ini bukan tidak mungkin akan mendorong makin maraknya peradilan pertanahan di masa depan.

Menghadapi sengketa pertanahan, beberapa pengacara antara lain Hotman Poris, menganjurkan BPN sudah waktunya mengembangkan Peradilan Ad Hoc Sengketa Pertanahan. Pakar hukum Irawan Soerodjo bahkan menyatakan sudah merupakan kebutuhan mutlak dibentuk Pengadilan Agraria yang merupakan mekanisme jalan keluar dari sejumlah sengketa agraria, agar proses peradilan dapat berlangsung dengan baik, cepat dan tepat sehingga tidak ada konflik kompetensi antara Peradilan TUN dan Peradilan Umum. Dengan demikian masalah penentuan kepastian hak atas sebidang tanah yang tengah disengketakan menjadi kompetensi Pengadilan Agraria yang secara ideal akan memeriksa perkara tersebut secara komprehensif

Untuk mengatasi kelangkaan hakim ahli hukum Pertanahan sebagaimana diungkapkan diatas, pasal 135 Undang-undang No. 5 tahun 1986 tentang Peradilan Tata Usaha Negara memberi jalan keluar yaitu memungkinkan adanya Hakim Ad Hoc. Terhadap Hakum Ad Hoc sebagai anggota majelis, lengkapnya berbunyi sebagai berikut : "Dalam hal pengadilan memeriksa dan memutuskan perkara Tata Usaha Negara tertentu yang memerlukan keahlian khusus maka ketua pengadilan dapat menunjuk seorang Hakim Ad Hoc sebagai anggota majelis"

Namun peraturan pemerintah yang akan mengatur tentang Hakim ad Hoc diatas sebagaimana yang diamanatkan oleh pasal 135 Undang-undang No. 5 tersebut diatas, sampai sekarang belum ada.

Urgency dari Hakim Ad Hoc maupun Hakim Khusus Peradilan Pertanahan/Agraria, pada saat ini sudah mendesak namun untuk melangkah ke arah itu Badan Pertanahan Nasional terlebih dahulu harus sudah menerapkan tertib administrasi di bidang pertanahan, di samping menerapkan tertib hukum pertanahan secara nasional, karena pada saat ini baik penerapan tertib administrasi pertanahan maupun tertib hukum pertanahan di jajaran Badan Pertanahan belumlah secara menyeluruh karena tidak jarang di kantor-kantor pertanahan di daerah penerapan administrasi dan hukum pertanahan masih sering berbeda satu dengan yang lain, padahal terwujudnya kedua "tertib" sangat penting untuk menunjang terwujudnya catur tertib pertanahan yang terdiri dari : tertib 
administrasi pertanahan, tertib hukum pertanahan, tertib penggunaan dan pemilikan tanah serta tertib lingkungan hidup.

Mengingat uraian-uraian tersebut di atas tentang sangat terbatasnya jumlah hakim ahli khusus di bidang pertanahan, sedangkan kasus-kasus yang masuk di Peradilan Tata Usaha Negara bagian terbesar adalah menyangkut masalah-masalah pertanahan dan mengingat pula bahwa tanah adalah objek dan unsur yang terpenting di dalam pembangunan fisik pada saat ini dan saat mendatang, kiranya memang perlu melalui proses pengadilan dapat dihasilkan putusan-putusan pengadilan yang tidak bertentangan dengan prinsip-prinsip hukum pertanahan nasional sebagaimana sekarang ini sering dirasakan putusan suatu Lembaga Peradilan tidak terlaksana karena menurut pandangan dari instansi pertanahan putusan tersebut bertentangan dengan prinsip-prinsip hukum pertanahan nasional sehingga sulit dilaksanakan.

Dalam suatu negara hukum seyogyanya tidak ada suatu putusan pengadilan yang tidak dapat dilaksanakan, instansi terkait harus melaksanakan suatu putusan pengadilan yang sudah mempunyai kekuatan pasti dan tetap.

Hakim Peradilan Khusus di bidang pertanahan tidak mutlak harus berasal dari kalangan instansi pertanahan, mungkin saja hakim tersebut berasal dari kalangan perguruan tinggi yang betul-betul menguasai hukum pertanahan bahkan masuk dalam kategori Pakar Hukum Pertanahan. Mengingat seorang Hakim itu diangkat oleh Presiden selaku kepala negara, maka sorang Hakim Khusus Pertanahan pun seyogyanya diangkat oleh Presiden. Oleh karena itu semua tingkat satu memiliki Peradilan Tata Usaha Negara, sebaiknya Hakim tersebut diangkat untuk seluruh wilayah Hukum di Indonesia dan sebaiknya pula Hakim tersebut ada, mulai dari Pengadilan Tata Usaha Negara, Pengadilan Tinggi Tata Usaha Negara dan tingkat Mahkamah Agung.

\section{Hakim Sebagai Figur Sentral Lembaga Peradilan Pertanahan/Agraria}

Telah banyak kasus-kasus di Pengadilan yang diputuskan oleh hakim yang kemudian dipertanyakan apakah hakim melakukan diskriminasi terhadap para pencari keadilan ?. Kasus OJ Simpson di Amerika Serikat pun sampai saat ini masih menjadi bahan kajian yang menarik. Hakim adalah sosok manusi yang selain mempunyai profesionalisme dan idealisme juga mempunyai kepentingan tertentu. Maka pada tahun 1980-an terjadi kehebohan ketika Pakar Sosiologi Hukum Prof.DR.Satjipto Rahardjo menyatakan bahwa putusan hakim ditentukan oleh sarapan paginya.

Akankah hakim di Lembaga Peradilan Pertanahan/Agraria juga demikian?

Masalah pertanahan berkaitan dengan penguasaan peraturan maka acapkali di sidang-sidang pengadilan Majelis Hakim yang menyidangkan kasus-kasus yang menyangkut pertanahan memerlukan bantuan seorang saksi ahli yang akan dijadikan acuan bagi majelis Hakim tersebut dalam menyusun putusan tentang perkara yang ditanganinya tersebut. Gambaran tersebut bukan berarti hakim-hakim Indonesia tidak memahami hukum-hukum pertanahan tetapi harus diakui karena banyaknya produk-produk hukum Pertanahan yang setiap saat dikeluarkan oleh Badan Pertanahan Nasional sedangkan waktu untuk mengikuti, mempelajari kemudian memahami peraturan-peraturan tersebut bagi para hakim karena banyak perkara-perkara yang ditangani sangat bervariasi, apalagi hakim di Indonesia sebagaimana halnya pada praktisi hukum lainnya belum mengenal adanya spesialisasi maka di Indonesiapun Hakim Perdata dan Hakim Pidana adalah satu, sehingga tidak mungkin mengharapkan dari hakim-hakim yang ada untuk menguasai semua peraturan tadi dengan baik.

Berdasarkan pengamatan berbagai pihak kasus-kasus yang terdaftar di Pengadilan Tata Usaha Negara lebih dari separuhnya menyangkut masalah tanah, yang tentu saja untuk menanganinya dengan baik diperlukan tenaga-tenaga hakim yang menguasai hukum-hukum dan peraturanperaturan yang menyangkut masalah pertanahan dengan baik pula. 
Tidaklah dapat dipungkiri materi dari Sumber Daya Manusia para hakim tidak terkecuali yang ada di Peradilan Tata Usaha Negara saat ini dalam menyelesaikan sengketa-sengketa pertanahan masih banyak yang belum menguasai dan memahami hukum-hukum dan peraturan-peraturan pertanahan (kalaupun ada jumlahnya relatif sangat terbatas), dalam kualitas ahli, untuk masalah-masalah pertanahan, hal mana disebabkan hakim-hakim di Indonesia tidak diarahkan kepada spesialisasi permasalahan; mereka adalah hukum perdata sekaligus hakim pidana. Bidang keperdataan saja sudah sangat komplek apalagi harus menangani kasus-kasus pidana ditambah lagi kasus-kasus pertanahan yang diatur oleh sedemikian banyaknya peraturan-peraturan apakah itu keputusan Menteri ataukah itu peraturan Menteri dan lain sebagainya. Sudah seyogyanya hakim-hakim di Indonesia diarahkan pada spesialisasi tetapi untuk perlu banyak waktu yang cukup tinggi dalam persiapan prosesnya.

\section{BAB VI \\ KESIMPULAN DAN SARAN}

\section{A. Kesimpulan}

1. Sengketa Pertanahan mencakup aspek perdata, pidana dan administrasi sehingga dapat masuk dalam kompetensi Peradilan Umum dan Peradilan TUN.

2. Penanganan sengketa pertanahan harus dilakukan secara komprehensif sehingga tidak menimbulkan konflik kompetensi antara PTUN dengan Peradilan Umum ataupunkonflik kompetensi tentang pemeriksaan lembaga peradilan yang mana yang harus didahulukan atau yang berwenang memeriksa sengketa tersebut.

3. Selama periode tahun $1999-2004$ di 8 kota sampel terdapat 734 berkas sengketa tanah yang diajukan ke PTUN (259 perkara) dan Peradilan Umum (475 perkara), dari jumlah tersebut hanya 123 perkara yang dicabut yaitu di PTUN 54 perkara $(14 \%)$ dan di Peradilan Umum 69 perkara (13\%). Sedangkan di 6 Kabupaten Sampel terdapat 324 berkas sengketa tanah yang diajukan ke PTUN (127 perkara) dan Peradilan Umum (197 perkara), dari jumlah tersebut hanya 35 perkara yang dicabut yaitu di PTUN 19 perkara (15\%) dan di Peradilan Umum (16 perkara).

4. Hasil penelitian di PTUN Kabupaten Sampel menunjukkan bahwa dari 108 perkara yang diajukan di Kabupaten tersebut, posisi BPN/Kantor Pertanahan pada saat ini lebih banyak menang. Di Pengadilan Tingkat Pertama, dari 54 perkara yang telah diputus hakim 31 perkara (57\%) Kantor Pertanahan dinyatakan menang, 23 perkara (43\%) dinyatakan kalah dan 54 perkara lainnya masih dalam proses pemeriksaan. Selanjutnya di Pengadilan Banding, dari 37 perkara yang telah diputus, 24 perkara $(65 \%)$ dinyatakan menang, dan 13 perkara (35\%) dinyatakan kalah. Selanjutnya ditingkat Kasasi terdapat tujuh putusan, sebanyak sebelas putusan hakim dimana sebayak 7 putusan hakim (64 \%) BPN/Kantor Peranahan dinyatakan menang dan sebanyak 4 putusan (36\%) dinyatakan kalah. Selama periode 5 tahun hanya terdapat 16 perkara yang inkracht.

5. Penelitian di Peradilan Umum di enam Kabupaten Sampel, selama periode 1999 sampai 2004, terdapat 181 perkara yang diajukan ke Peradilan Umum. Di Pengadilan Tingkat Pertama, dari 141 perkara yang telah diputus hakim, 82 perkara (42 \%) Kantor Pertanahan dinyatakan menang, 59 perkara $(30 \%)$ dinyatakan kalah dan 40 perkara lainnya masih dalam proses pemeriksaan. Selanjutnya di Pengadilan Banding, dari 75 perkara yang diputus oleh majelis, 52 perkara (26\%) Kantor Pertanahan dinyatakan menang, 23 perkara (12\%) dinyatakan kalah. Sedangkan di tingkat Kasasi terdapat 16 putusan hakim, yang mana sebanyak 11 putusan (6\%) BPN/Kantor Pertanahan dinyatakan menang dan sebanyak 5 putusan $(3 \%)$ dinyatakan kalah. Selama periode 5 tahun terdapat 21 perkara yang mendapat putusan hakim yang bersifat tetap (Inkracht). 
Untuk Kota Sampel, selama periode 1999 sampai 2004, terdapat 471 perkara yang diajukan ke Peradilan Umum. Di Pengadilan Tingkat Pertama, dari 287 perkara yang telah diputus hakim, 189 perkara (35\%), Kantor Pertanahan dinyatakan menang, 96 perkara $(18 \%)$ dinyatakan kalah. Sebanyak 40 perkara lainnya masih dalam proses pemeriksaan. Selanjutnya di Pengadilan banding, dari 183 perkara yang diputus oleh majelis hakim, 136 perkara (26\%) Kantor Pertanahan dinyatakan menang, 47 perkara ( $9 \%$ ) dinyatakan kalah. Sedangkan di Tingkat Kasasi terdapat 10 putusan hakim, yang mana sebanyak 6 putusan BPN/Kantor Pertanahan dinyatakan menang dan sebanyak 4 putusan dinyatakan kalah. Selama periode 5 tahun terdapat 10 perkara yang mendapat putusan hakim yang bersifat tetap (inkracht).

6. Hakim PTUN dalam memeriksa perkara menggunakan tolok ukur sebagai penguian pasal 53 ayat 2 a, b, c UU Nomor 5 tahun 1986 bahwa surat keputusan dapat dinyatakan batal atau tidak sah apabila keputusan tersebut dikeluarkan bertentangan dengan peraturan perundang-undangan yang berlaku, melampaui batas kewenangan dan dengan swenang-wenang, dan dalam pertimbangan hukum Hakim TUN sering pula menyebutkan bahwa pejabat TUN (BPN) telah melaukan perbuatan yang bertentangan dengan nilainilai yang terkandung dalam Asas-asas Umum Pemerintahan Yang Baik.

7. Dimungkinkannya sengketa pertanahan diperiksa di 1 Badan Peradilan, dalam pelaksanaannya sering menimbulkan adanya pertentangan perbedaan putusan, pihak yang dimenangkan dalam putusan Peradilan TUN dapat berbalik menjadi pihak yang kalah dalam putusan Peradilan Umum, konflik seperti ini sangat berpengaruh pada kinerja BPN karena setipikat yang sudah dibatalkan berdasarkan putusan Peradilan TUN dapat dibatalkan lagi dalam putusan Peradilan Umum jika secara hukum terbukti adanya perbuatan melawan hukum atau adanya itikad buruk dalam penguasaan tanahnya.

\section{B. Saran}

Untuk mengeliminir meningkatnya sengketa pertanahan yang akan mempengaruhi kepercayaan masyarakat terhadap pejabat atau aparat BPN dan produk yang dihasilkannya maka ada beberapa alternatif solusinya.

1. Formulasi Penyempurnaan Peraturan ( PP Nomor 24 tahun 1997)

$>$ pasal 24 mengenai pembuktian hak lama dalam hal hak atas tanah tidak mempunyai/tidak lengkap bukti tertulisnya maka didasarkan kepada penguasaan fisik (surat keterangan), surat ini sering menimbulkan masalah yang mengakibatkan BPN digugat di Pengadilan. Seharusnya ada pasal yang menyatakan BPN memproses haknya berdasarkan bukti dari pemohon dan tidak mempunyai hak uji materiil.

$>$ pasal 32 bertentangan dengan pasal 14 ayat 1 UU Nomor 14 tahun 1970 tentang Pokok-Pokok Kekuasaan kehakiman bahwa Pengadilan tidak boleh menolak untuk memeriksa dan mengadili suatu perkara. Pasal 32 sering dikesampingkan oleh hakim karena pengajuan gugatan ke Pengadilan tidak mengenal daluarsa dan merupakan hak seseorang.

> Pasal 45 bahwa Kepala Kantor Pertanahan menolak melakukan pendaftaran peralihan atau pembebanan hak jika tanah yang bersangkutan merupakan obyek sengketa Pengadilan, pasal ini bertentangan dengan pasal 67 UU Nomor 5 tahun 1986 bahwa gugatan tidak menunda dilaksanakannya keputusan TUN.

\section{Koordinasi dan Sosialisasi Pertanahan}

$>$ Koordinasi dan sosialisasi peraturan pertanahan perlu terus ditingkatkan dengan instansi terkait terutama para Hakim, PPAT/Notaris, tokoh masyarakat/KAN.

$>$ Sosialisasi peraturan pertanahan sebaiknya sebelum diberlakukan agar dibahas dengan instansi terkait untuk penyempurnaan peraturan agar tidak terjadi tumpang 
tindih peraturan atau dapat menimbulkan penafsiran yang berbeda dan saling bertentangan.

> Seminar pertanahan dengan melibatkan instansi terkait seperti pengadilan, kejaksaan, kepolisian, Pemerintah daerah dan sebagainya.

3. Peradilan Khusus Pertanahan

> Sebagian besar responden Kanwil BPN setuju dibentuk peradilan khusus pertanahan, namun sebelumnya perlu dilakukan persiapan berupa seminar mapun pendekatan kepada pihak-pihak pengambil kebijakan yang berkompeten, peningkatan SDM yang profesional, penyiapan kelembagaan (organisasi) serta penyusunan undang-undang peradilan pertanahan.

> Sebagian besar responden Kantor Pertanahan juga setuju pembentukan peradilan khusus pertanahan dengan beberapa alasan :

- kurangnya pemahaman Hakim terhadap hukum pertanahan

- karena Peradilan Umum dan TUN tidak dapat memberikan pemecahan tentang kepastian hukum kepemilikan tanah

- pembentukan peradilan pertanahan perlu segera direalisir mengingat proses panjang dalam pemeriksaan perkara dan

- tingginya volume perkara pertanahan

\section{DAFTAR PUSTAKA}

\section{Buku-Buku dan Laporan Penelitian}

Ali, Achmad, Teori Hukum Empiris, Fakultas Hukum Universitas Hasanuddin, Makassar, 2003.

Harsono, Budi, UUPA (Sejarah Penyusunan, Isi dan Pelaksanaannya): Hukum Agraria Indonesia, Jakarta: Penerbit Djambatan,1994.

Harsono, Budi, Hukum Agraria Indonesia, Himpunan Peraturan-Peraturan Hukum Agraria Indonesia, Jakarta: Penerbit Djambatan,2000.

Hadjon, Philipus M, Pengantar Hukum Administrasi Indonesia, Yogyakarta, Gajah Mada University Press, 1994.

Kartini Soedjendro, Perjanjian Peralihan Hak Atas Tanah Yang Berpotensi Konflik, Disertasi, Universitas Diponegoro, Semarang, Penerbit Kanisius, 1999.

Kajian Pola Penyelesaian Masalah Pertanahan, Puslitbang BPN 2002.

Evaluasi Kebijakan Penyelesaian Masalah dan Sengketa Pertanahan, Kerjasama Puslitbang BPN dengan Lembaga Penelitian UNAIR, 2003

Friedman Lawrence, The Legal System A Social Science Perspective, Russel Sage Foundation, New York, 1975. 1998.

American Law, An Introduction, disadur oleh Wisnu Basuki, Tata Nusa Jakarta, 
Murad, Rusmadi, Penyelesaian Sengketa Hukum Hak atas Tanah di Indonesia, Bandung, Alumni, 2002.

Parlindungan, A.P, Pendaftaran Tanah di Indonesia, Mandar Maju,1990.

Soekanto, Soerjono, Pengantar Penelitian Hukum, Jakarta, Penerbit Universitas Indonesia (UIPress), 1984.

Soerodjo, Irawan, Kepastian Hukum Hak Atas Tanah di Indonesia, Surabaya, Arkola, 2003.

\section{B. Peraturan dan Perundang-undangan}

Undang-Undang No. 5 tahun 1960 tentang Ketentuan Dasar Pokok-Pokok Agraria

Undang-Undang No. 14/1970 tentang Ketentuan-Ketentuan Pokok Kekuasaan Kehakiman

Undang-Undang No. 14/1985 Mahkamah Agung

Undang-Undang No. 2/1986 Peradilan Umum

Undang-Undang No 5/1986 Pengadilan Tata Usaha Negara

Peraturan Pemerintah No. 24 tahun 1997 tentang Pendaftaran Tanah

PMNA/KaBPN Nomor 3 tahun 1997 tentang Ketentuan Pelaksanaan PP 24/1997 tentang Pendaftaran Tanah

Instruksi Menteri Negara Agraria/Ka BPN No. 3/1998 tentang Peningkatan Efisiensi dan Kualitas Pelayanan Masyarakat di Bidang Pertanahan

Peraturan Menteri Negara Agraria/Kepala Badan Pertanahan Nasional No.1 tahun 1999 tentang Tata Cara Penanganan Sengketa Pertanahan 